\title{
Impulzuslézerekkel módosított szén és szilícium felületek vizsgálata Raman-spektroszkópiával és ellipszometriai módszerekkel
}

\author{
Doktori (Ph.D.) értekezés \\ Szerző: \\ Csontos János \\ Témavezetők: \\ Dr. Tóth Zsolt \\ tudományos fömunkatárs \\ Dr. Budai Judit \\ tudományos munkatárs
}

Fizika Doktori Iskola

Fizika Intézet

SZTE-TTIK

Szeged

2018 


\section{Tartalomjegyzék:}

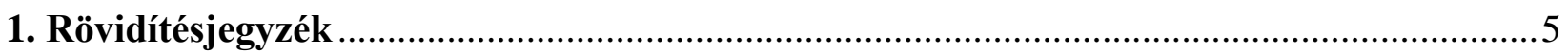

2. Elöszó

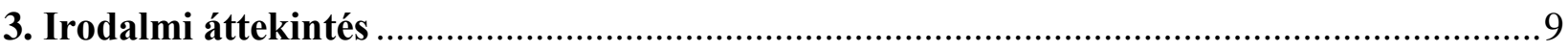

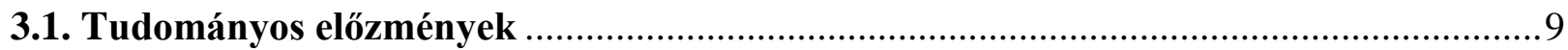

3.1.1. Szén módosulatok lézeres besugárzásának a kötésszerkezetre gyakorolt hatása .............. 9

3.1.2. Szén céltárgyakon keltett periodikus struktúrák ........................................................... 10

3.1.3. Ultragyors folyamatok ellipszometriai vizsgálata .................................................... 12

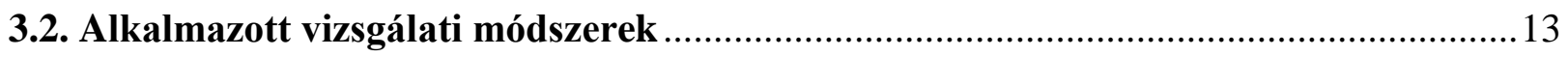

3.2.1. Pásztázó elektronmikroszkópia....................................................................................... 13

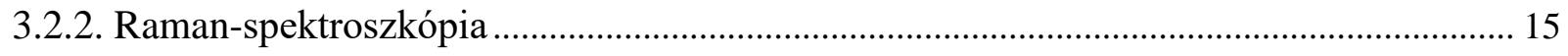

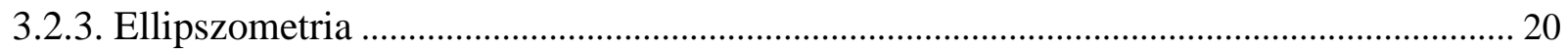

3.2.3.1. Spektrális ellipszometria ………………………………………………………..... 22

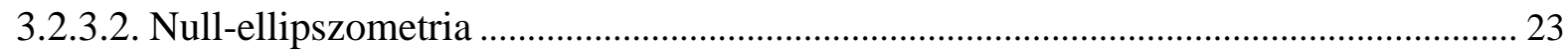

3.2.4. Kéthömérséklet modell .............................................................................................. 25

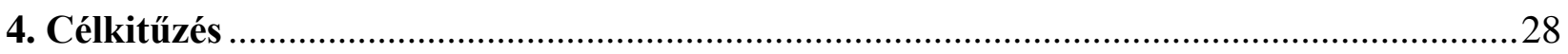

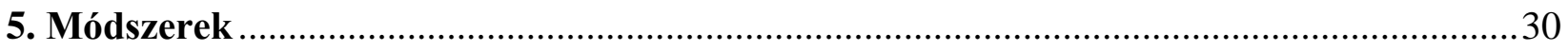

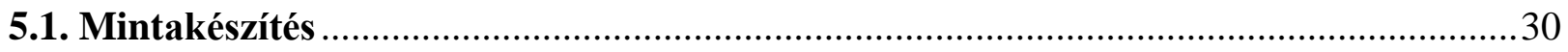

5.1.1. Üvegszerủ szén céltárgyak nagy intenzitású lézerekkel történő megmunkálása .............. 30

5.1.2. Üvegszerủ szén felszínének kezelése eltérő impulzushosszú lézerimpulzusokkal........... 31

5.1.3. Szilícium felszín ultrarövid lézerimpulzusokkal való gerjesztésének in-situ vizsgálata 33

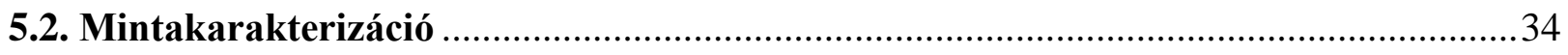

5.2.1. Pásztázó elektronmikroszkópia és az elektronmikroszkópos képek kiértékelése ............. 34

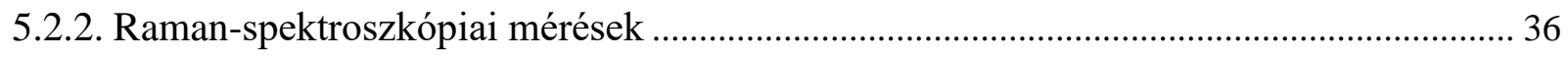

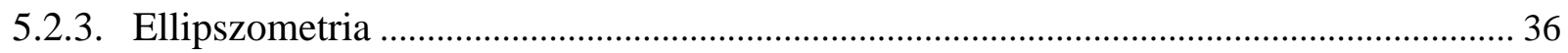


5.2.3.1. Forgó kompenzátoros ellipszométer formulái ....................................................... 38

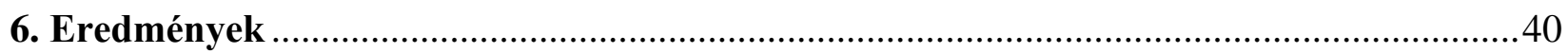

6.1. Impulzuslézerekkel módosított felületü üvegszerü szén céltárgyak Ramanspektrumának kiértékelése ....................................................................... 40

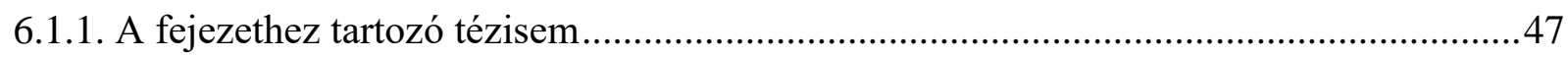

6.2. Impulzuslézerekkel módosított üvegszerü szén ex-situ vizsgálata ellipszometriával és Raman-spektroszkópiával ............................................................................ 48

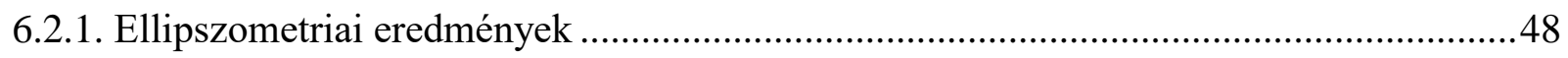

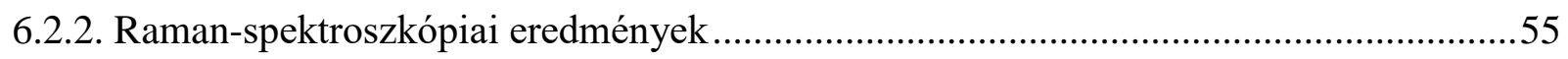

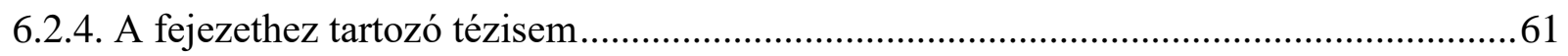

6.3. Üvegszerű szén felületeken impulzuslézerekkel kialakított periodikus struktúrák

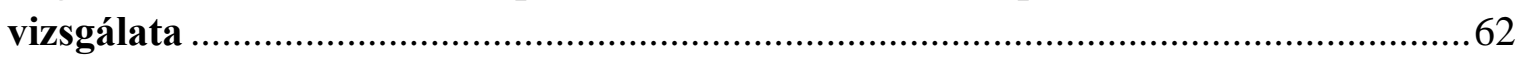

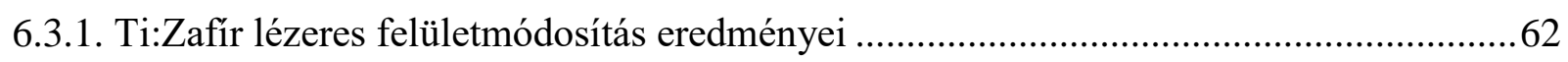

6.3.2. Festék-KrF lézeres felületmódosítás eredményei................................................69

6.3.3. Kötésszerkezet vizsgálata Raman-spektroszkópiával ..........................................72

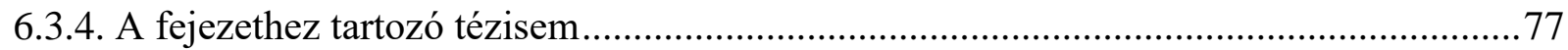

6.4. Pumpa-próba null-ellipszométer tervezése, megépítése és kalibrációja ultragyors

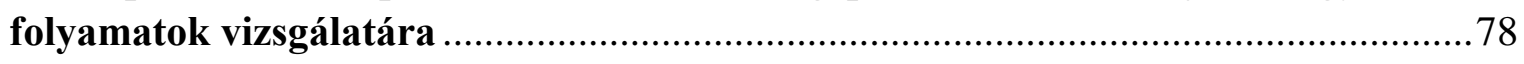

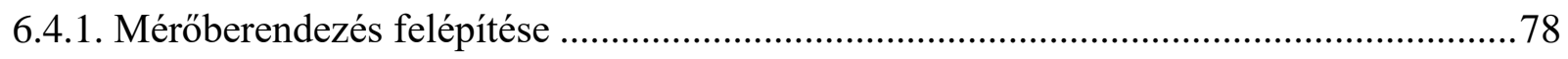

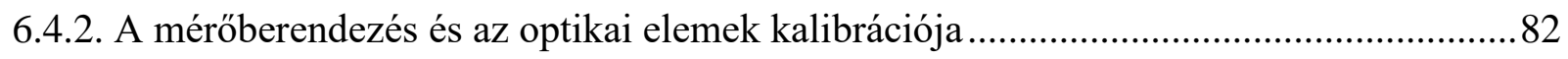

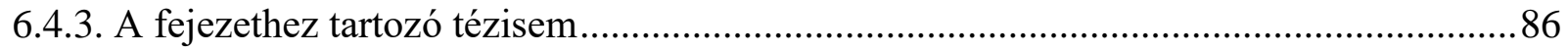

6.5. Tranziens optikai adatok vizsgálata pumpa-próba null-ellipszometriával ..................87

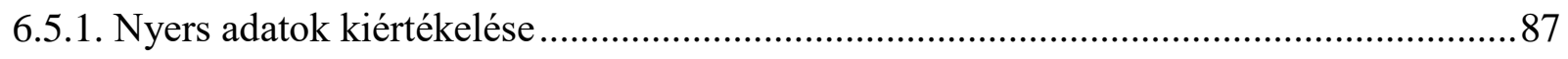

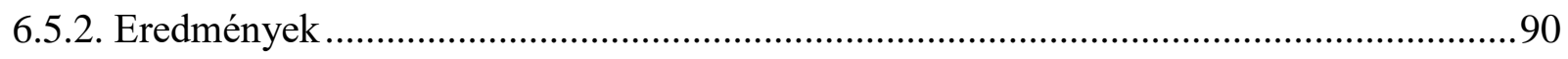

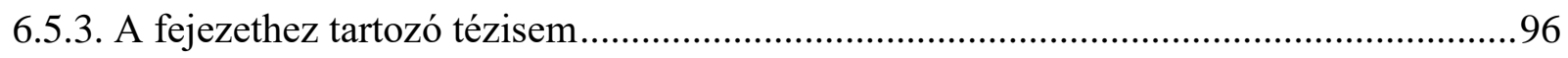

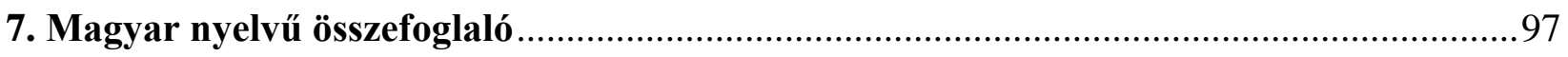

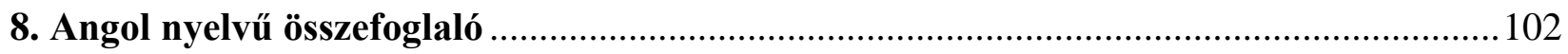




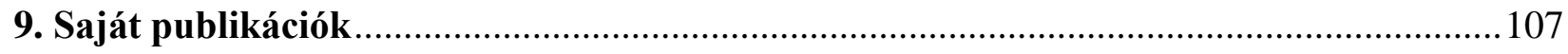

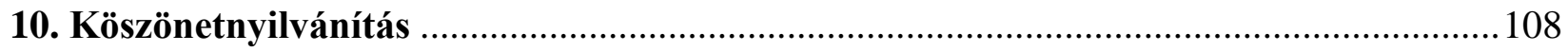

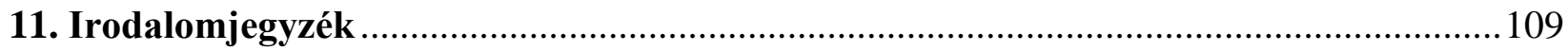




\section{Rövidítésjegyzék}

\begin{tabular}{|c|c|c|}
\hline Jelölés & Angol név & Leírás \\
\hline 2TM & Two Temperature Model & Kéthőmérséklet modell \\
\hline GC & Glassy Carbon & Üvegszerü szén \\
\hline TE & Volumetric Energy Density & Térfogati Energiasürüség \\
\hline FFT & Fast Fourier Transformation & Gyors Fourier-transzformáció \\
\hline LIPSS & $\begin{array}{l}\text { Laser Induced Periodic } \\
\text { Surface Structures }\end{array}$ & $\begin{array}{l}\text { Lézer indukált periodikus felületi } \\
\text { struktúra }\end{array}$ \\
\hline HSFL & $\begin{array}{l}\text { High Spatial Frequency } \\
\text { Laser Induced Structures }\end{array}$ & $\begin{array}{l}\text { Nagy térbeli frekvenciájú lézer } \\
\text { indukált periodikus felületi } \\
\text { struktúra }\end{array}$ \\
\hline LSFL & $\begin{array}{c}\text { Low Spatial Frequency Laser } \\
\text { Induced Structures }\end{array}$ & $\begin{array}{c}\text { Kis térbeli frekvenciájú lézer } \\
\text { indukált periodikus felületi } \\
\text { struktúra }\end{array}$ \\
\hline CPA & Chirped Pulse Amplification & Csörpölt impulzusú erősítés \\
\hline HOPG & $\begin{array}{c}\text { Highly Oriented Pyrolytic } \\
\text { Graphite }\end{array}$ & $\begin{array}{c}\text { Nagy rendezettségü pirolitikus } \\
\text { grafit }\end{array}$ \\
\hline $\mathbf{a}-\mathbf{C}$ & Amorphous Carbon & Amorf szén \\
\hline ta-C & $\begin{array}{c}\text { Tetrahedral Amorphous } \\
\text { Carbon }\end{array}$ & Tetraéderes amorf szén \\
\hline $\mathbf{a}-\mathbf{C}: \mathbf{H}$ & $\begin{array}{c}\text { Amorphous Hydrogenated } \\
\text { Carbon }\end{array}$ & Hidrogénezett amorf szén \\
\hline$\mu c$-grafit & Microcrystalline Graphite & Mikrokristályos grafit \\
\hline nc-grafit & Nanocrystalline Graphite & Nanokristályos grafit \\
\hline MSE & Mean Square Error & Közepes négyzetes hiba \\
\hline BBO & Beta Barium Borate & Béta-bárium-borát \\
\hline Si & Silicon & Szilícium \\
\hline
\end{tabular}




\section{ELŐSZÓ}

\section{Előszó}

A lézer 1960-as felfedezését követően világszerte erőteljes kutatás indult meg a lézer-anyag kölcsönhatás vizsgálata céljából. Napjainkban ezen kutatások eredményét hasznosítja az ipar, ahol a lézereket elterjedten használják gravírozásra, fúrásra, vágásra, hegesztésre. Lézerekkel az anyag strukturális, szerkezeti változását is elő tudjuk idézni, így az alkalmazható a szilárdtest felületek kifütésére, keményítésére, reflexiós tulajdonságainak megváltoztatására, újrakristályosítására. Noha ezen alkalmazási területek tudományos alapjait már régóta lefektették, a szilárdtestek szerkezetének átalakításával kapcsolatosan napjainkban is intenzív kutatás folyik. Ennek egyik oka, hogy a végbemenő folyamatokat a lézer paraméterei mellett a megmunkálni kívánt céltárgy anyaga is befolyásolja, ami miatt a kísérleti és az alkalmazási lehetőségek tárháza bőséges.

Impulzusüzemü lézerrel történő anyagmegmunkálás esetén az alkalmazott intenzitástól függően eltérő folyamatok valósulnak meg. Általánosságban elmondható, hogy kisebb intenzitások esetén a lézer által közölt energia az anyag felületének felmelegedését idézi elö. Nagyobb intenzitások esetén a minta nemcsak felmelegedik, de meg is olvadhat, valamint el is párologhat. Nagy $\left(>10^{6} \mathrm{~W} / \mathrm{cm}^{2}\right)$ teljesítménysürüség esetén az elpárolgott anyag ionizációja is fellép, ami következtében plazmafelhő képződik a minta felszínén.

Az impulzusidő szempontjából két tartományra bonthatjuk a lézer-anyag kölcsönhatást. Abban az esetben, ha lézerimpulzus hossza jóval meghaladja az elektron-rács kölcsönhatási időt, az elektron alrendszer termalizálódik az impulzus ideje alatt, azaz a két alrendszer hőmérséklete kiegyenlítődig. Ebben az esetben játszódnak le a klasszikus felfütési, olvadási és párolgási folyamatok. Ultrarövid impulzusok esetén az impulzus időbeli hossza kisebb, mint az elektron-rács kölcsönhatás karakterisztikus ideje. Ilyen esetben a céltárgyban az elektronok gerjesztése játszódik le elöször. Ez ahhoz a sajátos állapothoz vezet, hogy az elektron alrendszer hőmérséklete lényegesen nagyobb lesz a rácshőmérsékletnél. Ezt a jelenséget a kéthőmérséklet modell írja le. A kötésekből kiszakított nagy kinetikus energiájú elektronok szórási folyamatok során adják át az energiájukat a rácsszerkezetnek, amelyet nagyrészben el is hagynak. Az ionizált rácsot már nem tartják össze kötések, a pozitív ionok taszító hatása miatt a rács szétesik. Ezt a folyamatot nevezik Coulomb-robbanásnak, aminek a következményeként intenzív plazmaképződés jön létre. Emiatt a minta felszínén nemcsak a hőmérséklet, de a nyomás is megnövekszik, elérve akár több GPa-t [1]. 


\section{ELŐSZÓ}

Ezeket a folyamatokat erősen befolyásolják a lézerimpulzus további paraméterei, így a hullámhossz, az időbeli és térbeli koherencia, polarizáció, és a fény beesési szöge. A kialakuló jelenségek szempontjából meghatározó lehet, hogy a felületet mennyi lézerimpulzus éri (lövésszám), és természetesen meghatározó szerepe van az anyagi tulajdonságoknak is, mint például az anyag kémiai összetételének, kötésszerkezetének, mikroszerkezetének, az optikai, elektromos és hőtani tulajdonságoknak. Ezen paraméterek egyidejü figyelembevétele és a különböző lézerekkel történő anyagmegmunkálás összehasonlítása a meglehetősen sok paramétertér miatt nem egyszerü feladat.

A doktori kutatásaim első szakaszában különböző időbeli hosszúságú (néhány ns, valamint a fs - ps tartományba eső) lézerimpulzusok hatásait tanulmányoztam szén, illetve szilícium céltárgyakon. A megmunkálást követően, a lézerindukált folyamatok következményeit vizsgáltam ex-situ módszerekkel. Elsősorban optikai és elektronmikroszkópiát alkalmaztam a felületi struktúrák vizsgálatára. A szerkezeti változásokat Raman-spektroszkópia, valamint spektroszkópiai ellipszometria segítségével tanulmányoztam. Az ex-situ vizsgálatok alapján a lézerimpulzus-anyag kölcsönhatás időbeli lefutására csak következtetéseket tudunk felállítani. A doktori munkám második szakaszában ezért fordultam az in-situ vizsgálatok irányába, amelyekkel ezeket a folyamatokat az impulzuslézeres megmunkálás meglehetősen rövid ideje alatt is tanulmányozni lehet. A piko- vagy femtoszekundumos időskálán lejátszódó, viszonylag kis lézerintenzitással előidézett folyamatokat pumpa-próba technika segítségével vizsgáltam. Ez utóbbi módszerhez építettem egy pumpa-próba elrendezésben müködő ellipszométert, ami egy unikális laboratóriumi eszköz. Bár a kezdeti laboratóriumi lépések küzdelmesek voltak, sikerült méréseket végezni szubpikoszekundumos időbeli feloldással az ultrarövid lézerimpulzus szilícium felület kölcsönhatásának vizsgálatához. E mérések értelmezése céljából a munkám utolsó szakaszában a kéthőmérséklet modell felhasználásával egy elméleti leírást dolgoztam ki.

A doktori értekezésemet hét fejezetre osztottam. Az általam használt rövidítések feloldását a dolgozat elején adtam meg. Az elöszót követően a 2. fejezetben a dolgozatomhoz kapcsolódó kutatási területekről adok irodalmi összefoglalót. Ezt követően a 3. fejezetben bemutatom az alkalmazott vizsgálati módszerek fizikai hátterét. A 4. fejezetben megfogalmazom céljaimat, majd az 5. fejezetben rátérek a kísérleti körülmények, valamint az alkalmazott modellek ismertetésére. A 6. fejezetben ismertetem az elért eredményeimet, majd a 7. fejezetben az eredményeimet 
tézispontokban foglalom össze. Ezt követik az angol nyelvü összefoglaló, a saját publikációs jegyzék, és a köszönetnyilvánítás. Végül a dolgozatomat az elkészítése során felhasznált irodalmi források listájával zárom. 


\section{Irodalmi áttekintés}

\subsection{Tudományos elözmények}

\subsubsection{Szén módosulatok lézeres besugárzásának a kötésszerkezetre gyakorolt hatása}

Impulzusüzemü lézerrel történő anyagmegmunkálás esetén, a minta felszínén kialakuló hőmérséklet, illetve nyomás jelentősen függ a lézer paramétereitől, úgymint az impulzus energiájától, időtartamától, hullámhosszától, időbeli kontrasztjától, stb. A felületen és az alatta lévő tartományban kialakuló hőmérséklet-, illetve nyomáseloszlás nagymértékben befolyásolja a mintában létrejövő szerkezeti változásokat. A lézeres besugárzás kötésszerkezetre gyakorolt hatása szén céltárgyakon jól vizsgálható, mivel oxidjai légnemüek, így a megmunkálás során keletkező oxidált formája nem "szennyezi" a felszínt. Továbbá a különféle kötésszerkezeti formái, allotróp módosulatai igen eltérő optikai, mechanikai tulajdonságokkal rendelkeznek, így lézerrel megmunkált szén céltárgyak ex-situ vizsgálatával következtetéseket lehet levonni a lézeres besugárzás során kialakuló körülményekröl.

A szénnek, mint kémiai anyagnak, szilárd állapotban számos megjelenési formája ismert. Az allotróp kristályos módosulatok a grafit és a gyémánt, a makromolekuláris megjelenési formák például a fullerének és a nanocsövek. A rendezett és rendezetlen szerkezetek közötti átmenetre példa az üvegszerü szén, továbbá rendezetlen kötésszerkezetet mutatnak a különféle amorf módosulatok is. Attól függően, hogy a szén atomok kötésében részt vevő négy vegyértékelektron milyen kötést létesít, megkülönböztetünk $\mathrm{sp}, \mathrm{sp}^{2}$ és $\mathrm{sp}^{3}$ hibridizált állapotokat. A gyémánt a keménységét a tetraéderes szimmetriát mutató $\mathrm{sp}^{3}$-as kötések által meghatározott kristályszerkezetnek köszönheti. A grafitban az $\mathrm{sp}^{2}$-es hibrid kötések alakítják ki a hatszöges szimmetriájú grafén síkokat, amelyek közt delokalizált elektronok létesítenek gyenge, fémes jellegü kötést. Azonban vannak olyan szén módosulatok, mint amilyenek az amorf szenek, ahol egyszerre előfordulhatnak $\mathrm{sp}^{2}$ és $\mathrm{sp}^{3}$-as kötések is. Abban az esetben, ha az amorf módosulatban az $\mathrm{sp}^{3}$-as kötések vannak túlsúlyban gyémántszerủ amorf szénröl, ha pedig az $\mathrm{sp}^{2}$-es kötések dominanciája érvényesül, grafitszerủ amorf szénről beszélünk [2].

Számos kutatás foglalkozott már amorf, illetve nagyobb rendezettségi fokkal rendelkező szén módosulatok lézeres megmunkálásával, vizsgálva az atomkötések hibridizációs fokának változását. Nagy rendezettségi fokú pirolitikus grafit (HOPG) ArF lézerrel történő megmunkálása során Mechler Ádám és munkatársai azt tapasztalták [3], hogy $15 \mathrm{~J} / \mathrm{cm}^{2}$-es energiasürüség felett 
amorf szén jelenik meg a felületen. Nanoszekundumos excimer, illetve frekvenciakétszerezett Nd:YAG lézerimpulzusokkal létrehozott lökéshullámokkal a szén céltárgy felületi keményítését is el lehet érni [4,5]. A felület keményedését Bonelli és munkatársai [6] is tapasztalták, akik grafit felszínén gyémánt részecskék megjelenését figyelték meg, nagy energiájú $\left(250 \mathrm{~J} / \mathrm{cm}^{2}\right)$ impulzusokkal történő felületi kezelést követően. Más kutatók ultrarövid lézerimpulzusokat használtak HOPG minták megmunkálására, és az $\mathrm{sp}^{3}$-as kötések koncentrációnövekedését tapasztalták, amit a vékony, de nagymértékben felfütött rétegvastagsággal magyaráztak [7]. Ezt a megfigyelést molekuladinamikai szimulációk is alátámasztották [8]. A számos kutatás ellenére még mindig maradtak nyitott kérdések, amik miatt érdemes további kísérleteket végezni szén módosulatok lézerrel való kölcsönhatása tekintetében. Így doktori tanulmányaim során célom volt megvizsgálni, azt a kérdést, hogy szükséges-e az sp³-as kötések koncentrációjának növeléséhez nagy rendezettségi fokkal rendelkező szén céltárgy (mint amilyen a HOPG), vagy megvalósítható olyan anyagok esetén is, amelyek nem rendelkeznek nagy rendezettségi fokkal, azonban nem is amorfak, mint például az üvegszerủ szén.

\subsubsection{Szén céltárgyakon keltett periodikus struktúrák}

A minta felszínén létrehozott változások egy másik nagy csoportját alkotják a lézerrel létrehozott periodikus struktúrák. Ilyen, strukturált mintákat számos célból alkalmaznak, így például az aktív felület megnövelésére, nedvesítési tulajdonságok megváltoztatására, védőrétegek létrehozására [9-12], fémek reflexiós tulajdonságainak megváltoztatására [13], félvezetők abszorpciós tulajdonságainak javítására [14]. A felületi struktúra létrehozásához impulzusüzemü lézereket alkalmaznak, amelyek impulzushossza a nanoszekundumos tartománytól a femtoszekundumosig terjedhet. A folyamat angol elnevezéséből, a Laser Induced Periodic Surface Structure szavak kezdőbetűi alapján csak LIPSS-nek rövidített jelenséget nem sokkal a lézer felfedezését követően Birnbaum figyelte meg, miután félvezetőket munkált meg rubinlézerrel [15]. A létrehozott periodikus struktúrákat a periodicitásuk alapján két különböző kategóriába sorolják. Az első esetben a struktúrák periodikus távolsága a megmunkáló lézer hullámhosszánál nagyobb, vagy összemérhető azzal. Ezeket az angol Low Spatial Frequency LIPSS alapján LSFL-nek szokás nevezni. High Spatial Frequency LIPSS szavak után HSFL-nek nevezik [16] azokat a periodikus 
struktúrákat, amelyek a lézer hullámhosszának fele, vagy annál is kisebb karakterisztikus távolsággal rendelkeznek.

A lézerrel létrehozott struktúrák tulajdonságai a minta anyagi tulajdonságai mellett nagyban függnek a céltárgyat körülvevő anyagtól, ami lehet légnemü vagy folyékony [17, 18]. E mellett fontos paraméter még a lézer hullámhossza [19], az alkalmazott energiasűrüség [20, 21] és impulzusszám [22, 23]. A lézerrel létrehozott periodikus felületi struktúrákkal kapcsolatban számos lehetséges kialakulási folyamatot említenek az irodalomban [24], mint például:

- a beérkező és a felületi struktúrákon szóródó impulzus interferenciája [19, 25-28],

- a lézeres besugárzás következtében létrejövő felületi plazmon, amely kölcsönhat az impulzussal [19, 29-31],

- a felületen megolvadt rétegben létrejövő hidrodinamikai instabilitások, kapilláris hullámok $[19,32-35]$

- lézerfény felharmonikusai [36-40] és

- önrendeződés [41-43].

A struktúrák kialakulása mögött megbúvó fizikai folyamatok megosztják a tudományos közösséget, így ez még mindig egy intenzíven kutatott terület. Számos kutatás történt szén módosulatokon létrehozott felületi struktúrákkal kapcsolatban is. Ezek közül jó néhány eredményezett a megvilágító lézer hullámhossznál jóval kisebb periodikus struktúrákat. Huang és munkatársai [44] például grafiton, Ti:Zafír lézerrel létrehozott, 70-, 120-, és 170 nm-es periódushosszal rendelkező felületi struktúrák megjelenését írták le. Golosov és kollégái [45] szintén grafitot munkáltak meg Ti:Zafír lézer segítségével és $110 \mathrm{~nm}$-es periodikus távolsággal rendelkező nanorácsot hoztak létre. Az irodalomban található olyan kutatási eredmény is, amely 70- és $100 \mathrm{~nm}$-es periódusú struktúrák létrejöttéről számol be HOPG [46], illetve többrétegü grafén [47] femtoszekundumos lézerrel történő megmunkálása esetén. Ezen kutatások és csoportok közül valamennyi a beérkező lézer és a felületen keltett plazmonok interferenciájával magyarázta a HSFL létrejöttét. Ugyanakkor Zhang és csoportja a minta felszínén keltett másodharmonikus interferenciájával magyarázta [48] a HOPG-n femtoszekundumos lézerrel keltett, a hullámhossznál rövidebb szerkezetek megjelenését. Azonban ahogy Golosov [45], úgy Zhang is megfigyelt a lézer 


\section{IRODALMI ÁTTEKINTÉS}

hullámhosszával közel azonos periodikus távolsággal rendelkező struktúrákat is. Hasonlóan, Popescu és csoportja gyémántszerü szénrétegek pikoszekundumos, 532 nm-es hullámhosszú lézerrel történt megvilágítása után, LSFL és HSFL megjelenését is tapasztalta a minta felszínén [49]. Ezekben a kutatásokban a megmunkáló lézer impulzushosszát nem változtatták. Azonban azonos impulzusenergia és hullámhossz mellett az impulzushossz változtatásával eltérő folyamatok válnak dominánssá, így bővebb információ kapható a struktúrákat létrehozó folyamatról, ami felveti ilyen irányú kísérletek elvégzésének igényét.

\subsubsection{Ultragyors folyamatok ellipszometriai vizsgálata}

Olyan anyagok, illetve vizsgálandó paraméterek esetén, amelyeknél az ex-situ vizsgálati módszer nem ad elegendő információt, a lézer-anyag kölcsönhatás során lejátszódó fizikai folyamatok mélyebb megismeréséhez fontos a folyamatok in-situ módon történő vizsgálata is. Erre adnak lehetőséget az ún. pumpa-próba módszerek, amelyek során a pumpa impulzus kölcsönhat a mintával, majd egy időben késleltetett próba impulzus segítségével detektáljuk a minta felszínén végbemenő változásokat. A két impulzus közti késleltetés változtatásával a kölcsönhatás folyamata időben "letapogatható". A folyamat időbeli felbontása függ a késleltetés pontosságától, valamint az impulzusok hosszától.

Nagy intenzitású femto-, illetve pikoszekundumos impulzusokkal szigetelő, vagy félvezető anyagok besugárzása esetén, a minta felszínén nagy elektronkoncentráció hozható létre, ami megváltoztatja annak reflexiós, valamint abszorpciós tulajdonságait. Ennek a jelenségnek köszönhetően, a pumpa-próba kísérleti módszerrel számos kutató vizsgálta már az anyagok reflexiójának tranziens viselkedését [50-56]. Az anyagok abszorpciója, illetve dielektromos függvényük képzetes része azonban nem vizsgálható egyszerü reflexiós kísérletekkel. Ezzel szemben, ha a mintáról reflektált fény polarizációs állapotának változását vizsgáljuk, akkor már lehetöségünk van ezen paraméterek meghatározására. A vizsgáló fény $\mathrm{s}$ és $\mathrm{p}$ polarizált komponenseinek intenzitás- és fázisváltozásait vizsgáló módszer az ellipszometria. Hagyományos körülmények között az ellipszometriai mérések lassúak, nem képesek femto- vagy pikoszekundumos skálán lejátszódó folyamatok nyomonkövetésére. A pumpa-próba elrendezésben müködő ellipszométerek azonban ezt a problémát képesek áthidalni, ahogy azt kutatások meg is mutatták. Auston és munkatársai például pumpa-próba elrendezésben működő 
ellipszométerrel vizsgálták a lézerrel gerjesztett plazma sürüségét, valamint a szabad töltéshordozók időbeli változását adalékolatlan germániumban [57]. Choo és munkatársai a dielektromos függvény tranziens viselkedését vizsgálták $620 \mathrm{~nm}$-es hullámhosszú, alacsony intenzitású 100 fs-os impulzusokkal megvilágított Ge-Si fóliákon [58]. Boschini és munkatársai olyan elrendezést alakítottak ki, amellyel spektrálisan lehetett nyomon követni a $\mathrm{CrO}_{2}$ dielektromos tenzorának és magneto-optikai tulajdonságainak tranziens jellegü változásait [59]. A komplex törésmutató tranziens jellegü változását vizsgálták Rapp és munkatársai, 1056 nm-es 680 fs-os, illetve 528 nm-es 540 fs-os impulzusokkal megvilágított molibdén mintán, az ablációs küszöb alatt és felett [60]. E publikációk közös sajátsága, hogy minden esetben saját építésü készülékeket használtak, mivel a kereskedelemben ilyen mérésekhez nincs berendezés. Ennek megfelelően ez a mérési módszer nem elterjedt. Így például Si esetén a tranziens optikai mérések csupán reflexiós és transzmissziós paraméterek meghatározására terjedtek ki, Bergner és kollégái által [61]. Ezen irodalmi adatok kiegészítése a dielektromos függvények tranziens jellegü változásaival a femto-, szub-pikoszekundumos tartományban hasznos lehet a lézeres anyagmegmunkálás során lejátszódó folyamatok mélyebb megértéséhez.

\subsection{Alkalmazott vizsgálati módszerek}

Az alábbi fejezetben általános áttekintést adok a doktori munkám során használt kísérleti vizsgálati módszerekről és elméleti modellekről. Az első alfejezetben röviden áttekintem a pásztázó elektronmikroszkópia alapjait, hiszen a felületek morfológiai változásait elsősorban egy téremissziós pásztázó elektronmikroszkóppal vizsgáltam. Ezután röviden ismertetem a Ramanspektroszkópia fizikai hátterét, majd részletesebben írok a szén módosulatok Ramanspektroszkópiájáról. Ezt követően rátérek az ellipszometria leírására, ahol kitérek a spektroszkópiai ellipszometriára, valamint a null-ellipszometriára is. A fejezetet az ultrarövid lézerimpulzus-anyag kölcsönhatásait leíró elméletek közül a szilíciumra vonatkozó kéthőmérséklet modell leírása zárja.

\subsubsection{Pásztázó elektronmikroszkópia}

A morfológiai változásokat a lézerrel kezelt felületeken pásztázó elektronmikroszkóp segítségével vizsgáltam. A képalkotásnak két fő típusa létezik. Az egyik a leképezés, amelyet a 


\section{IRODALMI ÁTTEKINTÉS}

hagyományos optikai mikroszkópokban, vagy transzmissziós elektronmikroszkópokban figyelhetünk meg. Ebben az esetben a mintáról szóródó, vagy az azon áthaladó hullámot lencserendszer képezi le a detektorra, ami lehet a szemünk, egy fluoreszcens ernyő vagy egy CCD kamera. A másik típusa a képalkotásnak az, amikor a minta különböző pontjaiból érkező információt külön-külön rögzítjük. Ezt nevezik pásztázásnak, melynek megvan az az előnye, hogy alacsony jelszint esetén a detektálás idejét növelve jobb jel-zaj viszony érhető el. Ilyen módszerrel müködik a pásztázó elektronmikroszkóp is, ahol fókuszált elektronnyaláb pásztázásával "tapogatják" le a minta felszínét. Ezek az elektronok szóródhatnak, illetve másodlagos elektronokat keltethetnek a mintán. Ez utóbbi folyamat eredményeként az atom egy belső héjáról elektron lökődik ki, melynek a helyét egy külső pályán lévő elektron tölti be. A folyamat során felszabaduló energiát vagy egy karakterisztikus röntgensugárzás, vagy egy másik elektron (amit Augerelektronnak neveznek) viszi el. Emellett még keletkezhet fékezési sugárzás, katódlumineszcencia, illetve hő is. A fókuszált elektronnyaláb és az anyag kölcsönhatásaként létrejövő sugárzásokat rögzítik a pásztázás során, mely alapján másodlagos- vagy visszaszórt elektron-, röntgen- vagy katódlumineszcencia képekről beszélhetünk. Míg vékony minták esetén általában a szóródott és transzmittált elektronokat detektálják (pásztázó transzmittált elektron üzemmód), addig vastagabb minták esetén leggyakrabban a másodlagos illetve a visszaszórt elektronokat lehet rögzíteni. A kis kinetikus energiájú másodlagos elektronokkal a felszín változásairól, míg visszaszórt elektronképek segítségével a visszaszórási hatásfok rendszámfüggősége miatt a minta néhány 100 nm-es felső rétegének összetételéről kapunk információt [62]. A legjobb feloldást a másodlagos elektronképek adják: a feloldást ekkor lényegében a fókusz kiterjedése határozza meg. Korszerü, kisméretű elektronforrást biztosító téremissziós elektronmikroszkóppal elérhető az 1 nm-es feloldás. Így ez az eszköz jól használható kis periódusú struktúrák vizsgálatára. A pásztázó elektronmikroszkóp három legfőbb előnye az atomi erő mikroszkópiával (AFM: atomic force microscopy) szemben az, hogy mentes az AFM tük geometriája miatt fellépő torzításoktól, a képfelvétel ideje töredéke az AFM-hez képest, és a nagyítása tág határok között változtatható, ami alkalmassá teszi átnézeti képek és nagy nagyítású lokalizált képek felvételére is. 


\subsubsection{Raman-spektroszkópia}

Napjainkban széleskörüen alkalmazzák különféle anyagok kötésszerkezetének, ezen belül szén módosulatok vizsgálatára a Raman-spektroszkópiát. A mérési módszer alapja a fény rugalmatlan szórási folyamata, amelyet felfedezőjéről C. V. Ramanról neveztek el. Raman kísérletei során megfigyelte, hogy ha egyes anyagokat intenzív fénnyel világít meg, és vizsgálja az anyagról szóródó fény spektrumát, akkor a megvilágító fény hullámhosszán kívül más komponensek is megjelennek. Ez nevezik rugalmatlan, vagy más néven Raman-szórási folyamatnak [63]. A szórási folyamat során a beérkező fotonok az anyagban elektronokat gerjesztenek egy virtuális nívóra, elektron-lyuk párokat hozva ezzel létre. Rugalmatlan szórás esetén, kristályos anyagokban ezek az elektronok a rácsrezgésekkel, más néven fononokkal hatnak kölcsön. Amorf anyagok esetén, mivel fononokról nem beszélhetünk, a folyamatban a szerkezeti egységek térben lokalizált rezgései vesznek részt. Ehhez a szórási folyamat során teljesülni kell annak a rezgésekre vonatkozó kiválasztási feltételnek, miszerint a közeg polarizálhatóságának meg kell változni. Ezt követően az elektron-lyuk párok rekombinálódnak, amely folyamat következtében egy fotont bocsájtanak ki. Ennek a fotonnak az energiája, hullámhossza attól függ, hogy az elektron energiája a rezgéssel való kölcsönhatás után mekkora volt. Abban az esetben, ha a kölcsönhatás során az elektron energiát veszített, akkor a rekombináció során egy, az eredetinél kisebb energiájú foton keletkezik. Ezt a folyamatot nevezik Stokesi-folyamatnak. Fordított esetben az elektron-lyuk pár rekombinációja során egy, az eredetinél, nagyobb energiájú foton keletkezik, amit anti-Stokesi folyamatnak neveznek [64]. Az anti-Stokesi Raman-szórás valószínüsége kisebb, mivel ehhez az szükséges, hogy az anyagban már egy magasabb rezgési nívón lévő elektron további gerjesztése valósuljon meg.

A szórási folyamatokat szemlélteti az 1. ábra, ahol jól látható a Rayleigh- (azaz rugalmas szórás) és a Raman-szórások energiasémája, illetve az azokhoz tartozó spektrális jelalak. 


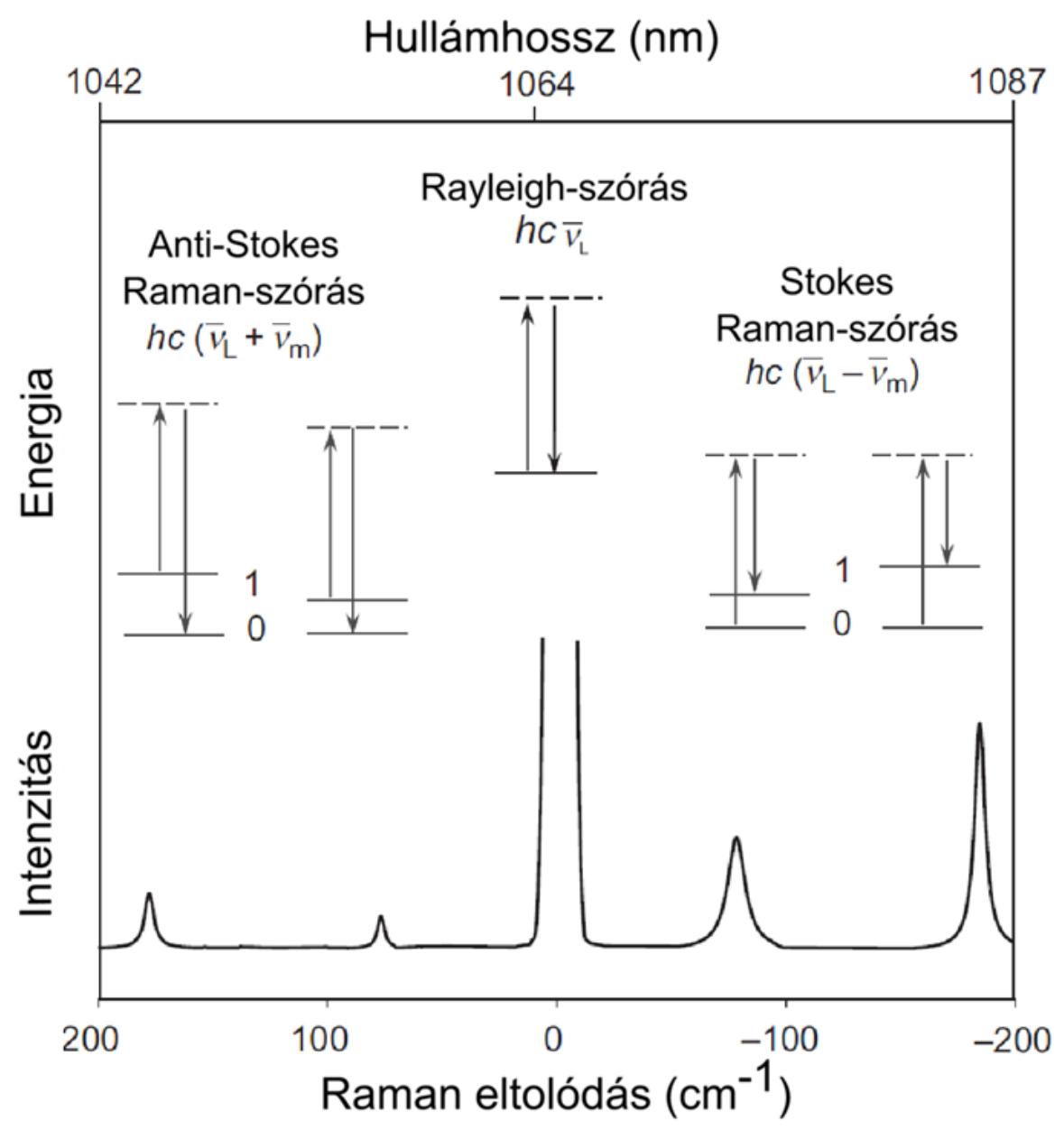

1. ábra: A rugalmas és rugalmatlan szórási folyamatok szemléltetése. Az ábra közepén, $0 \mathrm{~cm}^{-1}$ hullámszámnál, azaz a gerjesztés hullámhosszán (ebben az esetben ez 1064nm) látható a rugalmas szóráshoz tartozó spektrumcsúcs (alul), illetve az energiaséma (felül). A jobb-és baloldalon az anti-Stokesi-, illetve a Stokesi-folyamatokhoz tartozó rugalmatlan szórási folyamatok spektruma és energiasémája látható. Az ábra [65]-es hivatkozás alapján készült.

Általánosságban elmondható, hogy a rugalmatlanul szórt fotonok eltolódásának mértéke lényegében független a gerjesztő lézer hullámhosszától. Ebből az okból kifolyólag a spektrumokat jellemzően a megvilágító fényforráshoz képesti eltolódás függvényében, hullámszámban (az ábrán az alsó x tengely) szokták ábrázolni. A gerjesztő lézer hullámhosszának $0 \mathrm{~cm}^{-1}$ Raman-eltolódás felel meg. A Stokesi-, illetve anti-Stokesi-folyamatokhoz tartozó spektrumokat a hullámszám tengely ellentétes előjelủ részén szokás ábrázolni. Az ábrán az is jól látható, hogy az anti-Stokesifolyamathoz tartozó spektrum intenzitása kisebb, a folyamat kisebb valószínűsége miatt. 
A Raman-szórási hatásfoka rendkívül kicsi, a beérkező fotonok mennyiségéhez képest a rugalmatlanul szóródó fotonok száma 6-8 nagyságrenddel is kevesebb lehet [66], ami indokolttá teszi a nagyintenzitású gerjesztő fényforrás használatát. Megjegyzendő, hogy ha a gerjesztő fény az elektronokat egy valós nívó közelébe gerjeszti, rezonáns Raman-szórás valósul meg, ami következtében a rugalmatlan szórás valószínűsége megnő, így nagyobb lesz a Raman-jel intenzitása is. Ahogy az, az 1. ábrán is látható, a szórási spektrumban a gerjesztő fényforrás hullámhosszához képest az eltolódások rendkívül kicsik is lehetnek. Emiatt a fényforrásnak monokromatikusnak kell lennie. A nagy intenzitás és a monokromatikusság feltételei miatt használnak a gyakorlatban lézereket fényforrásként. A gyenge intenzitású szórt jel detektálására, régebben fotoelektron-sokszorozóval felszerelt monokromátorokat használtak, de a nagy érzékenységü CCD detektorok térhódításával manapság már elterjedtebbek az ilyen típusú detektorokkal szerelt spektrográfok.

\subsubsection{Szénmódosulatok Raman-spektroszkópiája}

A szénmódosulatok eltérő kötésszerkezete miatt azok Raman-spektrumai nagymértékben különböznek. A 2. ábrán látható gyémánt, grafit, mikrokristályos grafit ( $\mu \mathrm{c}$-grafit), üvegszerü szén (GC), valamint különböző amorf szén (porlasztott a-C, hidrogénezett a-C, tetraéderes a-C) Ramanspektrumai. 


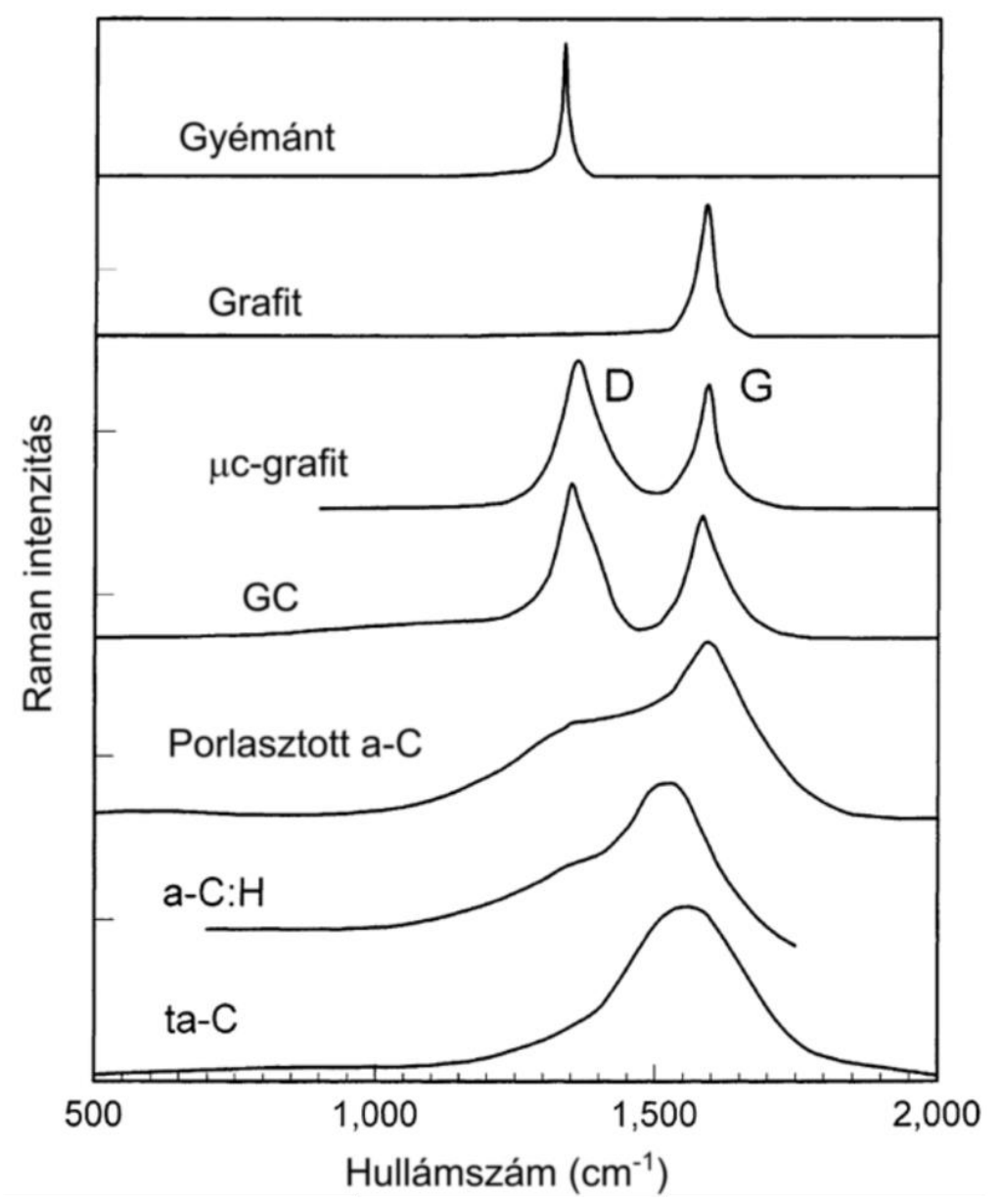

2. ábra: Különbözö szén módosulatok Raman-spektrumai. Az ábra a [67] hivatkozás alapján készült.

A gyémánt esetén $1332 \mathrm{~cm}^{-1}$-nél egy éles csúcs látható, amely az sp ${ }^{3}$-as hibridizált kötések rezgéseire jellemző. Grafit esetén a rendezett síkokban a szén atomok $\mathrm{sp}^{2}$-es hibridizált kötést alkotnak, ami miatt a spektrumban $\sim 1590 \mathrm{~cm}^{-1}$-nél jelentkezik egy csúcs, amire az irodalomban G sávként szoktak hivatkozni [68]. Mikrokristályos grafit esetén a kötésszerkezetben jelentkező hibahelyek miatt a $\mathrm{G}$ csúcs mellett egy másik sáv is megjelenik, $\sim 1340 \mathrm{~cm}^{-1}$-nél, amelyet $\mathrm{D}$ csúcsnak neveznek. Az ábrán látható negyedik görbe az üvegszerü szén spektruma, amely esetén szintén megjelennek a D és a G csúcsok, viszont eltérő jellegüek a korábbihoz képest, amiket az eltérő kötésszerkezeti környezet okoz. GC esetén az sp²-es hibridizált szénatomok alkotta síkok (azoknál a mintáknál, amiket a kísérleteim során használtan, jellemzően 2-4 sík) feltekerednek, így alkotva egy rendkívül kemény anyagot. Így az üvegszerü szén nem amorf szén, azonban hosszabbtávú kristálytani rendezettséggel nem rendelkezik [69]. Az irodalomban a G sávot az sp²- 


\section{IRODALMI ÁTTEKINTÉS}

es hibridizált szén-szén kötések nyújtási-, a D csúcsot pedig a hat szénatom által alkotott gyürük lélegző rezgéseivel azonosítják [67]. Továbbá egyes szén módosulatok esetén, mint például az üvegszerủ szénnél is, $1620 \mathrm{~cm}^{-1}$-nél, a G sáv mellékcsúcsaként, az irodalomban D'-nek (egyes helyeken D2-nek) nevezett sáv jelenik meg, ami szintén a rendezetlen kötésszerkezet jele [70 -74]. A kötésszerkezetben jelentkező hibákra nemcsak a D sáv megjelenése, de a csúcsok kiszélesedése is utal. Ilyet tapasztalhatunk amorf szenek esetén is, ahol az eddig bemutatott D és G sávok egyaránt megjelennek, azonban az előállításuktól függően a csúcsok paraméterei (intenzitása, félértékszélessége, pozíciója) nagymértékben változhatnak. Egyes esetekben akár olyan szélesek is lehetnek, hogy nem is különülnek el egymástól. Mivel ilyen szenek esetén az sp ${ }^{3}$-as hibridizált kötéstípus is jelen lehet, így akár a gyémántra jellemzö, $1332 \mathrm{~cm}^{-1}$-es csúcs is detektálható. Ehhez azonban nem használható a Raman-spektroszkópiában megszokott látható tartományba eső gerjesztés, UV lézer szükséges, mivel ilyen hullámhosszon az sp³ -as hibridizált kötések rezonánsan gerjeszthetők, továbbá a D csúcs intenzitása lecsökken, így az nem fedi el. Ezzel a módszerrel direkt módon detektálható akár alacsony koncentrációjú gyémánt kötések jelenléte is. Az sp³-as kötések detektálására létezik indirekt módszer is, amelyhez nem szükséges UV lézeres gerjesztés. Ennek egyik módja az $1150 \mathrm{~cm}^{-1}$ hullámszámnál jelentkező sáv észlelése, amit a nanokristályos gyémánt jeleként szoktak azonosítani [75]. Továbbá az sp³-as hibridizált kötések koncentrációjára a D és a G sávok tulajdonságaiból is lehet következtetni [67]. Ehhez a sávok intenzitásarányát, valamint a $\mathrm{G}$ sáv központi hullámszámát veszik figyelembe. Ezeknek a paramétereknek a változást szemlélteti a 3. ábra különböző szén módosulatok esetén. Az ábra Ferrari és kollégái által bevezetett háromfázisú modellt mutatja be, mely leírja a szénatomok kötéstípusainak változása során tapasztalt Raman-spektrumbeli változásokat [76]. Ha a minta nagy koncentrációban tartalmaz sp ${ }^{3}$-as hibridizált kötéseket (3-as ábra ta-C), a D és G sáv intenzitásaránya nulla. Az sp²es hibrid kötések koncentrációjának növekedésével a D és G sáv intenzitásaránya is növekszik. Továbbá növekvő $\mathrm{sp}^{2}$-es kötésekkel a $\mathrm{G}$ sáv pozíciója eleinte a kisebb, majd a nagyobb relatív hullámszámok felé tolódik el. Ezen megállapítások alapján elmondható, hogy a Ramanspektroszkópiai mérések egyszerü és roncsolásmentes lehetőséget szolgáltatnak a szén módosulatok anyagszerkezeti változásainak nyomon követésére. 


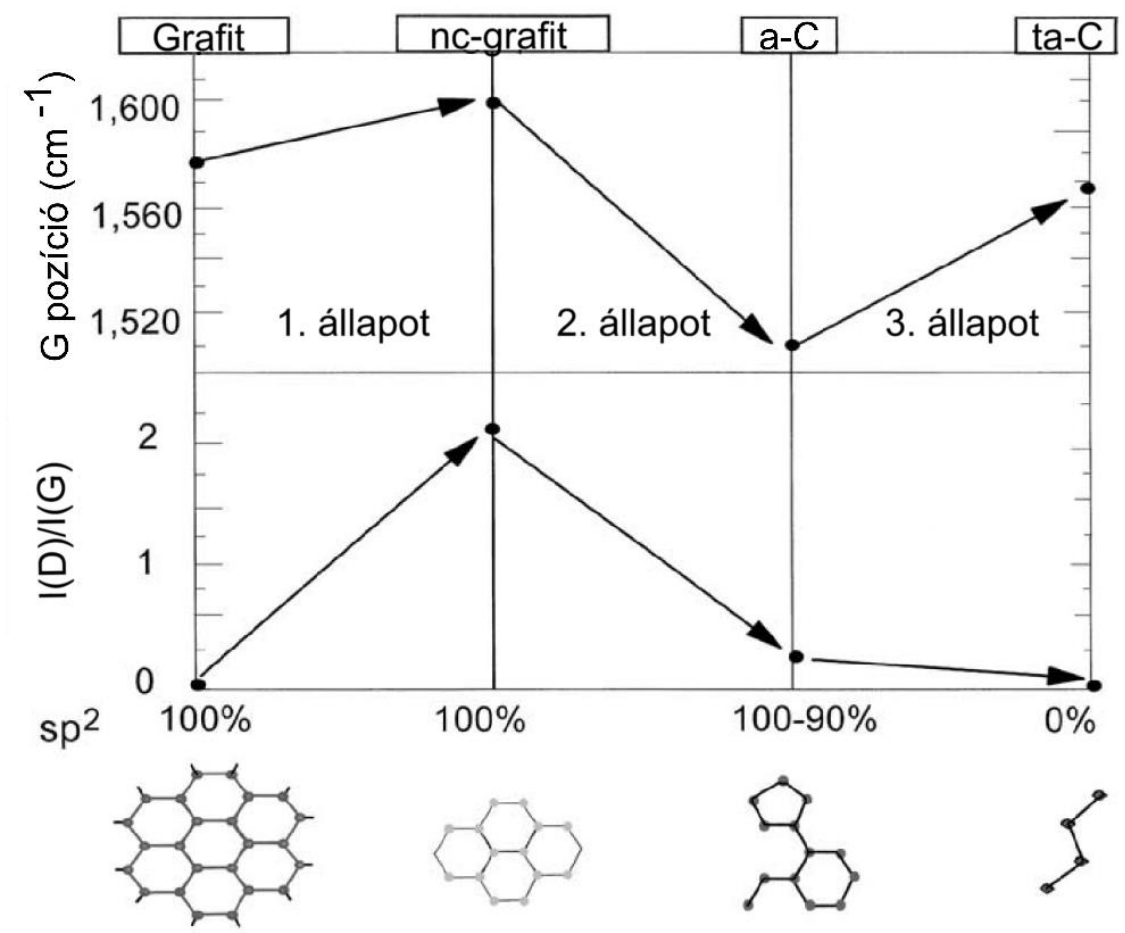

3. ábra: $A$ G sáv pozíciójának és a $D$ és $G$ csúcsok intenzitásarányának változása a különbözö szén módosulatok esetén. Az ábra felsö vízszintes tengelyén a szén módosulatok vannak feltüntetve, mint például a grafit, nanokristályos grafit (nc-grafit), amorf szén (a-C), illetve a tetraéderes amorf szén (ta-C). Ezekhez tartozó sp²-es hibrid kötések koncentrációja az alsó tengelyen látható. Az ábra a [76] hivatkozás alapján készült.

\subsubsection{Ellipszometria}

A sima felületü tömbi anyagok, illetve vékonyrétegek optikai adatainak, gyors és roncsolásmentes vizsgálatára teremt lehetőséget az ellipszometria, amely segítségével meghatározható a minta törésmutatója, abszorpciója, vékonyrétegek esetén pedig a réteg(ek) vastagsága. Az ellipszometria szempontjából a tömbi anyagok olyan anyagok, amelyek esetén a fény behatolási mélységében nem tapasztalható a közeg optikai tulajdonságaiban változás. A mérési módszer alapja az a tény, hogy a mintáról reflektálódó fény polarizációs állapotának változása információt hordoz magáról a mintáról. A minta vizsgálata során meghatározzuk a fény polarizációs állapotában a reflexió során bekövetkező változásokat. Ezeket az információkat a két ellipszometriai szög hordozza, melyeket $\Psi$-vel és $\Delta$-val szokás jelölni. A $\Psi$ értékét az (1)-es 
összefüggés írja le, ahol az $I_{p}$ és az $R_{p}$ a p polarizált, $I_{s}$, illetve az $R_{s}$ pedig az s polarizált elektromos tér beérkező $(I)$, valamint visszavert $(R)$ amplitúdói.

$$
\tan \Psi=\frac{R_{p} / I_{p}}{R_{s} / I_{s}}
$$

A $\Delta$ szöget, azaz a relatív fázisváltozást a (2)-es egyenlet írja le, ahol a $\mathrm{p}\left(\delta_{p i}, \delta_{p r}\right)$, illetve $\mathrm{s}$ $\left(\delta_{s i}, \delta_{s r}\right)$ polarizált komponensek fázisváltozásainak különbsége látható (itt az i index jelöli a beérkező, r pedig a reflektált fényre vonatkozó fázisváltozásokat).

$$
\Delta=\left(\delta_{p r}-\delta_{p i}\right)-\left(\delta_{s r}-\delta_{s i}\right)
$$

A komplex reflexiós amplitúdók használatával (amely az amplitúdó mellett tartalmazza a fázisváltozásokat is) felírható a (3)-as összefüggés, melyet az ellipszometria alapegyenletének neveznek. Itt $\widetilde{r_{p}}$, illetve az $\widetilde{r_{s}}$ jelöli a komplex reflexiós együtthatókat a két különböző polarizációs irány esetén [77].

$$
\tan \Psi e^{i \Delta}=\frac{\widetilde{R_{p}} / \widetilde{I_{p}}}{\widetilde{R_{s}} / \widetilde{I_{s}}}=\frac{\widetilde{r_{p}}}{\widetilde{r_{s}}}
$$

Tömbi anyagok esetén a komplex reflexiós együtthatókat a Fresnel-formula írja le a (4) és (5) egyenlet alapján.

$$
\begin{gathered}
\widetilde{r_{p}}=\frac{\widetilde{n_{a}} \cos \phi_{i}-\widetilde{n_{g}} \cos \phi_{t}}{\widetilde{n_{a}} \cos \phi_{i}+\widetilde{n_{g}} \cos \phi_{t}} \\
\widetilde{r_{s}}=\frac{\widetilde{n_{g}} \cos \phi_{i}-\widetilde{n_{a}} \cos \phi_{t}}{\widetilde{n_{g}} \cos \phi_{i}+\widetilde{n_{a}} \cos \phi_{t}}
\end{gathered}
$$

Itt az $\widetilde{n_{a}}$, illetve $\widetilde{n_{g}}$ az anyag, illetve az anyagot körülvevő közeg komplex törésmutatója, $\phi_{\mathrm{i}}$ illetve a $\phi_{t}$ pedig a beeső, illetve a megtört nyalábok beesési merőlegestől mért szögei [78]. Az anyag optikai paraméterei az $\widetilde{r_{p}}$, illetve $\widetilde{r_{s}}$ Fresnel-együtthatókból megkaphatók.

Abban az esetben, ha a minta felületén vékonyréteg, vagy vékonyréteg rendszer található, a komplex reflexiót már nem ilyen egyszerü formula írja le. Ilyenkor ugyanis figyelembe kell venni 
a rétegek határán kialakuló reflektált nyalábok között interferenciát. A rétegen áthaladó nyaláb fázisváltozása függ annak vastagságától, illetve a réteg, valamint a hordozó optikai tulajdonságaitól, ami miatt a réteg aljáról és tetejéről reflektált nyalábok eltérő fázisváltozást szenvednek el. Ennek köszönhetően a detektált ellipszometriai szögek információt hordoznak a rétegekről. Ilyen esetekben az optikai paraméterek meghatározása egy beesési szög esetén, egy hullámhosszon történt mérésből általában nem valósítható meg egyértelmúen. A több hullámhosszas, vagy egy szélesebb spektrális tartományban elvégzett mérések információtartama már lehetővé teszi a rétegek vastagságának és optikai adatainak meghatározását. A spektrális ellipszometriáról a következő alfejezetben írok.

\subsubsection{Spektrális ellipszometria}

A gyakorlatban az ellipszometriai szögek meghatározására számos kísérleti elrendezés létezik. Ezek felépítése általában nagymértékben hasonlít egymásra. A fény polarizációjának megváltoztatására szolgáló, és az egyéb optikai elemek két karban, egy-egy optikai tengelyre felfüzve helyezkednek el, amelyeknek dőlésszöge változtatható. Példaképp egy forgó kompenzátoros ellipszométer sematikus rajzát mutatom be a 4. ábrán.

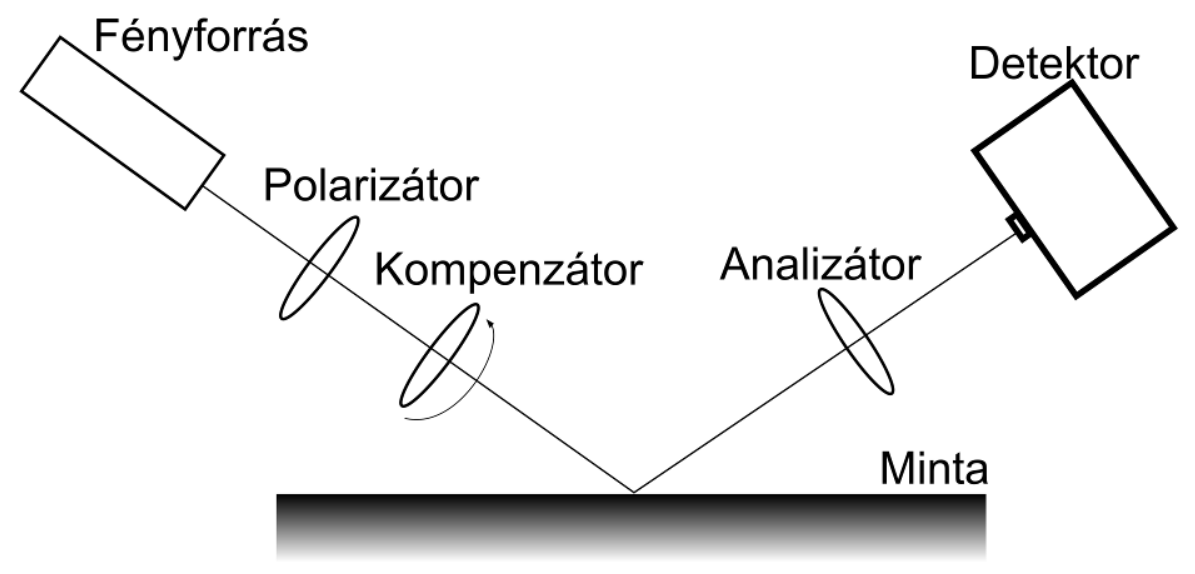

4. ábra: Forgó kompenzátoros ellipszométer sematikus rajza.

Spektroszkópiai mérés esetén a minta megvilágítására egy nagy teljesítményü, széles spektrális tartományon sugárzó fényforrást használnak (ez sok esetben egy xenon, vagy deutérium gázzal töltött kisülési lámpa). A párhuzamosítást követően a fény áthalad egy polarizátoron majd 
egy kompenzátoron, amely meghatározott szögsebességgel forog. Így a két polarizációs irány közt időben ismert fázistolást vezet be. A mintáról reflektálódó fény egy analizátornak nevezett polarizátoron halad keresztül, amit a spektrográf követ. A spektrális bontásnak köszönhetően minden egyes mért hullámhosszon meghatározható a fény periodikus intenzitásváltozása, amelyből megkaphatók a $\Psi$ és $\Delta$ értékek. Ezekből egy számítógépes kiértékelés segítségével a vizsgált rétegek vastagságát és komplex törésmutatójának diszperzióját lehet meghatározni. Általában mátrix formalizmust $[79,80]$ használva, a számítógépes algoritmusok iterációs eljárással végzik a mért adatok kiértékelését. Az ilyen eljárás első lépéseként feltételezünk egy modellt, amely tartalmazza a minta irodalomból ismert, vagy paraméteres függvényekkel jellemzett hullámhosszfüggő optikai adatait és rétegvastagságait. Ezt követően a számítógépes algoritmus addig változtatja az optikai paramétereket és a rétegvastagságokat, amíg hibahatáron belüli egyezést nem talál a mért értékek és a feltételezett modell alapján számolt értékek között. Az így meghatározott rétegvastagságok és hullámhosszfüggő optikai adatok fogják a vizsgált mintát jellemezni. Az ilyen típusú vizsgálati módszert nevezzük spektrális ellipszometriának.

\subsubsection{Null-ellipszometria}

Doktori munkám során megvalósítottam olyan kísérleteket, ahol Si optikai tulajdonságainak tranziens viselkedését vizsgáltam ultrarövid lézerimpulzusok okozta besugárzások során. Ezekhez egy pumpa-próba elrendezésben müködő null-ellipszométert építettem meg. A null-ellipszométer az első ellipszométerek közé tartozik, amelyet Drude is használt. Egy ilyen ellipszométer felépítése hasonlít az előbbiekben bemutatott forgó kompenzátoros ellipszométerre, azaz a fényúton végig haladva a polarizátor, kompenzátor, minta, analizátor sorrenddel találkozunk, azonban a mérés menete eltérö. A legfontosabb jellemzője a null-ellipszometriának, hogy egyetlen hullámhosszon mér. Ennél az ellipszométernél csak a polarizátor, illetve az analizátor beesési síktól mért, más néven azimutális szöge változik, a kompenzátor szöge változatlan marad. A detektorba jutó/az analizátort elhagyó térerősséget a (6)-es összefüggés írja le [78].

$$
\begin{aligned}
E_{A}=E_{P}\left\{r_{p} \cos (A)\left[\tau_{\text {fast }} \cos (C) \cos (P-C)-\tau_{\text {slow }} \sin (C) \sin (P-C)\right]\right. \\
\left.+r_{S} \sin (A)\left[\tau_{\text {fast }} \sin (C) \cos (P-C)+\tau_{\text {slow }} \cos (C) \sin (P-C)\right]\right\}
\end{aligned}
$$


Itt $E_{p}$ jelöli a polarizátor után a térerősségét, ahol $r_{p}$ és $r_{s}$ a p, illetve az s polarizációjú fény komplex reflexiós együtthatója, $A$ az analizátor, $C$ a kompenzátor, $P$ pedig a polarizátor azimutális szöge, $\tau_{\text {slow }}$ és $\tau_{\text {fast }}$ pedig a kompenzátor gyors és a lassú tengelyeire vonatkozó komplex transzmissziós együtthatók. A polarizátor, illetve az analizátor azimut szögének változtatásával elérhető olyan szögállás, ahol az analizátort követően a fény intenzitása 0 , azaz $E_{A}$ értéke 0 . Innen származik a mérési módszer elnevezése is. Ilyen esetben a (6)-os egyenletből a komplex reflexió értéke [77]:

$$
\rho \equiv \frac{r_{p}}{r_{s}}=-\tan \left(A_{0}\right) \frac{\tau_{C} \tan \left(P_{0}-C\right)+\tan (C)}{\tau_{C} \tan \left(P_{0}-C\right) \tan (C)-1}
$$

Ahol $\tau_{C}$ jelöli a $\tau_{\text {slow }}$ és a $\tau_{\text {fast }}$ szögek hányadosát, $A_{0}$ és $P_{0}$ jelöli az analizátor és polarizátor azimut szögét. Ha a kompenzátor fázistolása $90^{\circ}$, az azimutális szöge pedig $45^{\circ}$, akkor a fenti egyenlet leegyszerüsödik. Felhasználva ezt, illetve az

$$
e^{(-i 2 \theta)}=\frac{1-i \tan \theta}{1+i \tan \theta}
$$

összefüggést, a (7)-es formula az alábbi alakban írható [77]:

$$
\tan \Psi e^{i \Delta}=\tan (-A) e^{\left[i\left(-2 P+90^{\circ}\right)\right]}
$$

Ebből az ellipszometriai szögekre az alábbi egyszerü összefüggések adódnak [77]:

$$
\begin{gathered}
\Psi=-A \\
\Delta=-2 P-90^{\circ}
\end{gathered}
$$

Azaz, ha az analizátor és a polarizátor azimutális szögének hangolásával elérjük, hogy a detektorra ne jusson fény, akkor a keresett ellipszometriai szögeket a két azimutális szög leolvasásával megkaphatjuk. Látható, hogy monokromatikus fény alkalmazásával, ilyen típusú mérésekhez nem szükséges detektor, elegendő a saját szemünkre hagyatkozni a nullhelyzet meghatározásánál. Ennek a ténynek köszönhetően tudott Drude több mint 100 éve egy ilyen eszközzel méréseket végezni. 


\subsubsection{Kéthőmérséklet modell}

Lézerimpulzus és anyag kölcsönhatása esetén fontos információt nyújthat a céltárgy felületi hőmérsékletének változása, illetve ennek mélységbeli eloszlása. Rövidimpulzusok esetén a hőmérséklet kiszámolására széleskörúen alkalmazzák az úgynevezett kéthőmérséklet modellt (TTM). A modell két különböző hőmérséklettel jellemzi az anyag rács, illetve elektron alrendszerét. A felületre beérkező femto- vagy pikoszekundumos impulzus az elektron alrendszerrel hat kölcsön, amelynek átadva az energiát néhány femtoszekundum alatt felmelegíti azt. Az így elnyelt energia ütközések révén adódik át, és melegíti fel a rács alrendszert. Az ehhez tartozó időállandót nevezik termalizációs időnek, amely a lézerimpulzusnál jóval hosszabb, néhány tíz-száz pikoszekundumos tartományba esik. A kéthőmérséklet modell leírását elsőként Kaganov [81] és Anisimov [82] tette meg. Az általuk leírt modellben az elektron-, illetve a rácshőmérsékletet két különböző differenciálegyenlettel írják le, amelyek között az energia áramlását egy töltéshordozó-fonon csatolási tényező teremti meg.

Félvezetők esetén, mint amilyen a pumpa-próba ellipszometriai kísérleteim során használt szilícium is, az elnyelt lézerimpulzus szabad töltéshordozókat generál a mintában. Az alábbi differenciálegyenlet írja le az elektronkoncentráció változását időben, olyan esetben, amikor a minta felszínét egy időben változó $I$ intenzitású Gauss burkolójú fényimpulzus éri [83]:

$$
\frac{\partial N}{\partial t}=\frac{\alpha_{S P A} I}{\hbar \omega_{L}}+\delta N-\gamma N^{3}-\nabla \cdot J
$$

ahol $N$ az elektronkoncentráció, $\alpha_{S P A}$ az egyfotonos abszorpcióhoz, $\delta$ az impakt ionizációhoz, valamint $\gamma$ az Auger-rekombinációhoz tartozó együtthatók. A redukált Planck-állandót a $\hbar$ jelöli, $\omega_{L}$ a lézer központi körfrekvenciája, $J$ a töltéshordozó-áramsürüség. Az anyaggal kölcsönható fény intenzitását az I változó hordozza, amelyet egy időfüggő Gauss-függvénnyel vehető figyelembe:

$$
I(t)=I_{0}(1-R) e^{-4 \ln 2\left(\frac{t}{\tau_{p}}\right)^{2}}
$$

ahol $I_{0}$ a lézerimpulzus csúcsintenzitása, $R$ a reflektivitás és $\tau_{p}$ a lézerimpulzus hossza.

Az anyagon belül az lézerimpulzus intenzitását a mélység függvényében az alábbi differenciálegyenlet írja le: 


$$
\frac{d I}{d x}=-\left(\alpha_{S P A}+\alpha_{F C A}\right) I
$$

ahol $\alpha_{F C A}$ a szabad töltéshordozó abszorpció. A reflexiót és a szabad töltéshordozó abszorpciót az alábbi egyenletek írják le:

$$
\begin{aligned}
R & =\frac{|\tilde{n}-1|^{2}}{|\tilde{n}+1|^{2}} \\
\alpha_{F C A} & =\frac{2 \operatorname{Im}(\tilde{n}) \omega_{L}}{c}
\end{aligned}
$$

ahol $\tilde{n}$ az anyagra jellemző komplex törésmutató, $c$ pedig a fény vákuumbeli sebessége. A komplex törésmutató Drude-modell segítségével határozható meg, így az figyelembe veszi az elektronkoncentráció tranziens jellegü változását.

A rácshőmérsékletet leíró differenciálegyenlet az alábbi alakban írható fel:

$$
C_{p h} \frac{\partial T_{p h}}{\partial t}=\nabla \cdot\left(\kappa_{p h} \nabla T_{p h}\right)+g\left(T_{e}-T_{p h}\right)
$$

ahol, $C_{p h}$ a rács hőkapacitása, $T_{p h}$ a rácshőmérséklet, $k_{p h}$ a rács hővezetési együtthatója, $T_{e}$ az elektronhőmérséklet, $g$ pedig a töltéshordozó-fonon csatolási faktor.

Az elektronhőmérsékletre vonatkozó differenciálegyenlet pedig az alábbi alakban írható:

$$
C_{e} \frac{\partial T_{e}}{\partial t}=Q_{e}-\nabla \cdot W-g\left(T_{e}-T_{p h}\right)-\left(E_{g}+3 k_{B} T_{e}\right) \frac{\partial N}{\partial t}-N \frac{\partial E_{g}}{\partial t} .
$$

Itt $k_{B}$ a Boltzmann-állandó $C_{e}$ a töltéshordozók hőkapacitása, ami $3 k_{B} N$ alakban adható meg. Az abszorbeált lézer energiát $Q_{e}=\left(\alpha_{S P A}+\alpha_{F C A}\right) I$ adja meg. Az elektromos hő fluxusát a,

$$
W=J\left(E_{g}+3 k_{B} T_{e}\right)-\kappa_{e} \nabla T_{e}
$$

képlet írja le. Itt a szilícium tiltottsáv-szélességét $E_{g}$ jelöli, amely hömérséklet és elektronkoncentráció függő, szilíciumra vonatkozó értékét a I. táblázat tartalmazza. 


\begin{tabular}{ccc}
\hline \hline Jelölés & Formula & Mértékegység \\
\hline$\alpha_{S P A}$ & $-30,547 \cdot T_{p h}^{2}+31455 \cdot T_{p h}+2 \cdot 10^{8}$ & $1 / \mathrm{m}$ \\
$\delta[84]$ & $3,6 \cdot 10^{10} \cdot \exp \left(\frac{-1,5 \cdot E_{g}}{k_{B} T_{e}}\right)$ & $1 / \mathrm{s}$ \\
$\gamma[84]$ & $3,8 \cdot 10^{-31}$ & $\mathrm{~cm}^{6} / \mathrm{s}$ \\
$C_{p h}[84]$ & $1,978+3,54 \cdot 10^{-4} \cdot T_{p h}-3,68 \cdot T_{p h}^{-2}$ & $\mathrm{~J} / \mathrm{cm}^{3} \mathrm{~K}$ \\
$k_{p h}[84]$ & $1585 \cdot T_{p h}^{-1,23}$ & $\mathrm{~W} / \mathrm{cmK}$ \\
$E_{g}[83]$ & $1,16-\frac{7,02 \cdot 10^{-4} \cdot T_{p h}^{2}}{T_{p h}+1108}-1,5 \cdot 10^{-8} \cdot N^{1 / 3}$ & $\mathrm{eV}$ \\
$\mu_{h}[85]$ & $4,8 \cdot 10^{-2} \cdot\left(T_{p h} / 300\right)^{-2,5}$ & $\mathrm{~m}^{2} / \mathrm{Vs}$ \\
$\mu_{e}[85]$ & $1,35 \cdot 10^{-1} \cdot\left(T_{p h} / 300\right)^{-2,4}$ & $\mathrm{~m}^{2} / \mathrm{Vs}$ \\
\hline \hline
\end{tabular}

I. táblázat: A kéthömérséklet modell során használt paraméterek értékei.

A töltéshordozó áramsürüségét a $J$ változó jelöli, amit az alábbi egyenlet ír le:

$$
J=-D\left(\nabla N+\frac{N}{2 k_{B} T_{e}} \nabla E_{g}+\frac{N}{2 T_{e}} \nabla T_{e}\right)
$$

ahol $D$ jelöli az ambipoláris diffúzió együtthatóját, mely az alábbi alakban írható:

$$
D=\frac{2 k_{B} T_{e}}{e} \frac{\mu_{e}^{0} \mu_{h}^{0}}{\mu_{e}^{0}+\mu_{h}^{0}}
$$

Itt $e$ az elemi töltés valamint $\mu_{p h}$ és $\mu_{e}$ a lyuk- és elektronmozgékonyság. A töltéshordozófonon csatolási faktor megkapható, mint a töltéshordozó hőkapacitása és a töltéshordozó-fonon relaxációs idejének hányadosa: $g=C_{e} / \tau_{\text {relax }}$. 


\section{CÉLKITÜZÉS}

\section{Célkitüzés}

A doktori munkám során célom az volt, hogy a lézeres anyagmegmunkálás következtében a céltárgy felszínén kialakuló strukturális változásokat, valamint a megmunkálás során kialakuló fizikai körülményeket tanulmányozzam. Ehhez első kísérleteim során szén céltárgyat alkalmaztam. A szén strukturális és kötésszerkezetének változásai - ahogy azt a bevezetésben is említettem - jól jellemzik a lézerimpulzus és a mintafelület kölcsönhatása során kialakuló körülményeket. A szén kötésszerkezetének elterjedten használt vizsgálati módszere a Raman-spektroszkópia. Szén felületek módosítás során azonban általában egy módosított réteg jön létre a felületen, aminek a vastagsága sok esetben a Raman-spektroszkópiai mérés során használt fényforrás behatolási mélységénél kisebb, így a réteg alatt található hordozó Raman-jele megjelenik a mért spektrumban. Ilyen esetekben tehát a mérések, nem csak tisztán a rétegről adnak információt. Ha a spektrumban a módosult rétegre és a hordozóra jellemző sávok átfednek, akkor a nyers spektrumokból nehéz a rétegre vonatkozó következtetéseket levonni. Mindezek fényében:

- célul tűztem ki egy olyan módszer kidolgozását, amely segítségével lézerrel kezelt üvegszerü szén céltárgy felületén létrejövő vékonyréteg Raman-spektrumát lehet meghatározni.

- Továbbá célom volt üvegszerü szén céltárgyak eltérő paraméterekkel rendelkező lézerimpulzusokkal történő kezelése és a felületen végbemenő fizikai folyamatok mélyebb megismerése ex-situ vizsgálatok segítségével. Ehhez a mikroszkópos képek felvétele mellett Raman-spektroszkópiai és spektroszkópiai ellipszometriai méréseket terveztem megvalósítani a lézer által módosított felületeken, így követve a lézer okozta strukturális és kötésszerkezeti változásokat. Célom volt a mérési eredmények egy olyan értelmezése, amellyel összehasonlíthatóvá válnak a különböző impulzushosszakkal és hullámhosszakkal rendelkező lézeres megmunkálások eredményei.

A lézeres anyagmegmunkálás következtében a felület módosítása mellett felületi struktúrák is kialakulhatnak. Ezeknek a struktúráknak az alakja, illetve egyéb tulajdonságai a lézer paraméterein kívül a céltárgy anyagi minőségétől is függenek. Számos kutatás irányult ezeknek a folyamatoknak a mélyebb megértésére, ahol különböző anyagokon, különböző közegekben, eltérő impulzushosszú, energiájú, illetve hullámhosszú impulzusokkal hoztak létre struktúrákat. Azonban irodalmi kutatásom során nem találkoztam olyan szisztematikus kísérletsorozattal, mely során széles tartományon változtatták volna a lézer impulzushosszát, fixen tartva az egyéb paramétereket. 
- Ezek alapján meg akartam vizsgálni, hogy üvegszerü szén céltárgyakon, különböző lézerimpulzusok segítségével létrehozható-e periodikus felületi struktúra. Ezekhez a kísérleteimhez két, eltérő hullámhosszú lézer állt az SZTE Fizika Intézetében rendelkezésre, amelyeknél mód volt az impulzushosszak változtatására. A különböző impulzushosszak mellett kialakított felületi szerkezetek változásait elektronmikroszkópia segítségével terveztem vizsgálni.

A felületek lézerrel történő módosítása során a végbemenő folyamatokat jelentősen befolyásolja a céltárgy optikai tulajdonságainak változása a lézeres besugárzás közben. Mivel e tranziens tulajdonságok ismerete hozzájárul a lejátszódó folyamatok megértéséhez, ezért célul tüztem ki:

- egy pumpa-próba elrendezésben múködő ellipszométer létrehozását, amellyel optikai tulajdonságok tranziens változásai vizsgálhatók. Az elrendezés megépítését és kalibrációját követően célom volt kimérni, hogy szilícium szeletek ellipszometriai szögei hogyan változnak időben fs-os lézerimpulzussal történő besugárzást követően / során.

- Továbbá alá szerettem volna támasztani a mérési eljárás használhatóságát a mért, időfüggő ellipszometriai adatok értelmezésének megadásával. Ennek megfelelően célom volt a kéthőmérséklet modell segítségével meghatározni a szilícium rácshőmérsékletének és a töltéshordozó-sűrüségének időbeli változását, azaz meghatározni szilícium esetén lézeres besugárzás következtében fellépő tranziensváltozásokat. 


\section{Módszerek}

Ebben a fejezetben összefoglalom, hogy munkám során milyen kísérleti körülmények mellett készítettem mintákat, majd a minták karakterizálásához használt módszereket mutatom be röviden.

\subsection{Mintakészítés}

\subsection{1. Üvegszerủ szén céltárgyak nagy intenzitású lézerekkel történő megmunkálása}

A kísérleti munkám első szakaszában üvegszerü szén mintákon (SIGRADUR ${ }^{\circledR}$ G) különbözö lézerek impulzusaival módosított felületi rétegeket hoztam létre. A megmunkálás okozta felületi változások részletesebb tanulmányozása céljából több, különbözö hullámhosszú és impulzushosszú lézert használtam. Ezeket a lézereket a Szegedi Tudományegyetem Optikai és Kvantumelektronikai Tanszéke, illetve a Kísérleti Fizikai Tanszék Nagy Intenzitású Lézer Laboratóriuma (High Intenstiy Laser Laboratory: HILL) bocsátotta rendelkezésre a kutatásaimhoz. Az alkalmazott lézerek pontos paramétereit a II. táblázat tartalmazza.

\begin{tabular}{lcccc}
\hline \hline & $\begin{array}{c}\text { Festék- } \\
\text { KrF [86] }\end{array}$ & KrF & ArF & Nd:YAG \\
\hline Hullámhossz (nm) & 248 & 248 & 193 & 532 \\
Impulzushossz & $480 \mathrm{fs}$ & $18 \mathrm{~ns}$ & $20 \mathrm{~ns}$ & $8 \mathrm{~ns}$ \\
$\begin{array}{l}\text { Energiasürüség (J/cm²) } \\
\text { GC abszorpciós állandója }\end{array}$ & $0,14-0,57$ & $0,48-1,72$ & $0,52-1,52$ & $0,85-1,66$ \\
$\begin{array}{l}\text { adott hullámhosszon } \\
\times \mathbf{1 0}^{\mathbf{5}}(\mathbf{1} / \mathbf{c m})\end{array}$ & 8,6 & 8,6 & 2,3 & 2,5 \\
$\begin{array}{l}\text { Térfogati energiasúrüség } \\
\times \mathbf{1 0}^{\mathbf{5}}\left(\mathbf{J} / \mathbf{c m}^{\mathbf{3}}\right)\end{array}$ & $1,2-4,9$ & $4,1-14,8$ & $1,2-3,5$ & $2,1-4,2$ \\
\hline \hline
\end{tabular}

II. táblázat: A kisérlet során használt lézerek paraméterei és az alkalmazott energiasürüség, valamint térfogati energiasürüség értékek.

Mindegyik lézeres megmunkálás során a lézernyalábot egy 50 mm-es fókusztávolságú kvarc lencsével gyüjtöttem össze a minta felszínére. A céltárgyat a lencse fókuszsíkja elé helyeztem el 
úgy, hogy a távolság változtatásával szabályoztam a megvilágított területet, tehát az energiasürüséget a céltárgy felületén. Továbbá így értem el, hogy a megmunkált terület nagyobb legyen, mint az ellipszométer vizsgálófoltja, ami ahhoz volt szükséges, hogy az ellipszométeres mérési adatokat a megmunkált terület széle, vagy az azon kívül elhelyezkedő nem megmunkált terület ne befolyásolja. A kísérletek során a megmunkáló impulzusok számát 1 és 20 között, a céltárgy felületét érő energiasürüséget pedig jellemzően 0,5 és $1,5 \mathrm{~J} / \mathrm{cm}^{2}$ között változtattam. Adott lézer esetén a pontos tartományokat a II. táblázat tartalmazza. A festék-KrF lézeres kísérletek

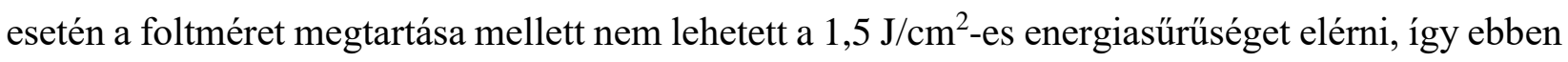
az esetben 0,14 és $0,57 \mathrm{~J} / \mathrm{cm}^{2}$ között tudtam azt változtatni. A kísérletek megkezdése előtt a céltárgy felületét a szennyeződésektől acetonnal, illetve etil-alkohollal tisztítottam meg.

Az anyag abszorpciós tulajdonsága nagymértékben befolyásolja a lézerimpulzus által a felületen létrehozott hömérsékletet, nyomást, illetve egyéb körülményeket. Az eredmények összehasonlítása során figyelembe kellett venni, hogy az eltérő hullámhosszon sugárzó lézerek behatolási mélysége eltérő, így különbözö térfogatú anyaggal közlik az energiát. Témavezetőim egy korábbi munkájukban már használták a térfogati energiasürüségnek nevezett mennyiséget hasonló esetekben [87]. Ez a mennyiség a felület megmunkáláshoz használt energia és annak a térfogatnak a hányadosa, amivel az energiát közöljük. Gyakorlatban ez nem más, mint az energiaürüség és az abszorpciós állandó szorzata. Az eredményeimet ennek a paraméternek a függvényében vizsgáltam, így figyelembe tudtam venni a különböző lézerek eltérő hullámhosszát. A II. táblázatban feltüntettem az üvegszerủ szénre vonatkozó abszorpciós állandókat a különböző hullámhosszak esetén, valamint az alkalmazott energiasürüség és a behatolási mélység alapján számolt térfogati energiasürüséget is.

\subsection{2. Üvegszerü szén felszínének kezelése eltérö impulzushosszú lézerimpulzusokkal}

A doktori munkám során a második feladatom üvegszerü szén felületén, periodikus struktúrák létrehozása és vizsgálata volt. Az egyik lézer egy Ti:Zafír alapú csörpölt impulzuserősítésű (Chirped Pulse Amplification: CPA) lézerrendszer volt, melynek központi hullámhossza $800 \mathrm{~nm}$, Fourier-transzformáció limitált impulzushossza pedig 35 fs. A kísérletek során az impulzushosszakat 35 fs, 300 fs, 2,4 ps, 30 ps és 200 ps-nak választottam meg. 2,4 ps esetén az impulzus időbeli hosszát akusztooptikai modulátor segítségével változtattam. Az 
akusztooptikai modulátor kettőstörő kristályában akusztikus hullámokkal a kristály törésmutatójának periodikus változását idézzük elő. A periodikus törésmutató változással lehet az impulzus spektrális fázisát befolyásolni, így a Fourier-transzformáció limitált 35 fs-os impulzus hosszát könnyedén meg lehetett növelni 300 fs-ra, illetve 2,4 ps-ra. A 30 ps-os impulzushossz eléréséhez egy vastag üvegtömböt helyeztem a fényútba, amin az impulzus keresztülhaladva az anyagi diszperzió miatt megnyúlt. A 200 ps-os impulzushosszhoz már egy Offner-féle impulzusnyújtót használtam. A 35 fs-os impulzushosszat egy Wizzler ultragyors impulzusmérő berendezéssel, a 200 ps-os impulzushosszat pedig egy spektrális interferometrián alapuló mérési módszer segítségével határoztam meg. A köztes impulzushosszakat a diszperzió hozzáadásával számoltam ki.

A második lézer a fentiekben már ismertetett festék-KrF lézerrendszer volt, mely $248 \mathrm{~nm}$-es hullámhosszú és 480 fs hosszúságú impulzusokat bocsát ki. A magimpulzusokat egy elosztott visszacsatolású 496 nm-en sugárzó festéklézer adja, amelyek frekvenciakétszerezés után kerülnek a KrF excimer erősítőbe. A kisüléssel gerjesztett excimer közegben 3 keresztülhaladás után néhány tíz mJ-ra erősödik az impulzus energiája. Fourier-transzformáció limitált, 250 fs-os hosszúságú impulzusok rácsos impulzuskompresszorral állíthatók elö. A festéklézer impulzusainak frekvenciakétszerezését biztosító $\mathrm{BBO}$ kristály vastagságának változtatásával hosszabb impulzusokat is el lehet érni. Vastagabb frekvenciakétszerező kristály esetén a frekvenciakétszerezett impulzus sávszélessége beszükül, mely magával vonja az impulzushossz megnyúlását. Így a kísérleteimhez elérhetővé váltak 1, illetve 2,1 ps-os impulzushosszak is. A kísérletek során használt impulzushosszakat a HILL laboratórium munkatársai autókorrelációs mérésekkel mérték meg.

A Ti:Zafír lézerrel végzett kísérletek során a lézernyalábot egy 65 mm-es fókusztávolságú lencsével gyüjtöttem össze az üvegszerü szén felszínére, így elérve, hogy a megmunkált folt átméröje $0,7 \mathrm{~mm}$ legyen. A festék-KrF lézer esetén egy $50 \mathrm{~mm}$-es fókusztávolságú kvarc lencsét használtam, mellyel 0,64 mm-es átmérőjü területeket munkáltam meg. A céltárgy felületén az energiasürüség mindkét lézer esetében $0,1 \mathrm{~J} / \mathrm{cm}^{2}$ volt. Az impulzusok lineárisan polarizáltak voltak, a polarizáció irányát az eredmények fejezetben közölt nagy felbontású elektronmikroszkópos képeken jelöltem. A megmunkáló impulzusok száma 1 és 100 között 10 különbözö értéken volt változtatva, azonban az eredmények ismertetése során csak az 1, 10 valamint a 100 lövéssel megmunkált mintákat mutatom be. 


\subsubsection{Szilícium felszín ultrarövid lézerimpulzusokkal való gerjesztésének in-situ vizsgálata}

Az ultrarövid lézerimpulzusokkal a felületen keltett folyamatok in-situ vizsgálatára gyakorta használják a reflexió tranziens változásának mérését. Munkám során azért választottam ellipszometriai méréseket, mert ezzel a minta dielektromos állandói meghatározhatók, így a megmunkálás során végbemenő folyamatok jobban leírhatók. Noha kísérleteimet célszerü lett volna a korábbi vizsgálataimhoz hasonlóan üvegszerü szén mintákon végezni, azonban olyan céltárggyal szerettem volna dolgozni, melynek optikai adatai az irodalomból jól ismertek. Így esett a választásom az egykristályos szilíciumra, amelynek az optikai tulajdonságai nem csak szobahőmérsékleten, de magasabb hőmérsékleten is adottak.

A méréseket úgynevezett pumpa-próba elrendezésben végeztem. Az ultrarövid pumpaimpulzusokkal kiváltott optikai hatást a pumpaimpulzusokhoz képest megfelelően késleltetett próbaimpulzusok segítségével vizsgáltam. A pumpa- és próbaimpulzusoknak a HILL laboratórium festék-KrF lézer 480 fs-os impulzushosszúságú 248 nm hullámhosszúságú UV impulzusait, illetve az elosztott visszacsatolású, ugyanilyen hosszúságú 498 nm-es hullámhosszúságú impulzusait alkalmaztam. A próbaimpulzusokat egy null-ellipszométer vizsgáló fényforrásaként használtam, és a szilícium mintán történő reflexiójuk során bekövetkező polarizációváltozásukat detektáltam. Az általam tervezett, megépített, és próbamérésekkel ellenőrzött képalkotó pumpa-próba null-ellipszométer müködését az eredmények fejezetben ismertetem részletesen.

A szilíciumszelet felületén, adott pontban, mindegyik késleltetés $(2,5,15,25,50,75,100$ és 146 ps) esetén 80 pumpa-próba mérést rögzítettem. Azért, hogy a besugárzás során ne változzon irreverzibilis módon a minta szerkezete, a felszínt a kísérleteim során kellően alacsony, UV impulzusonként maximálisan $17 \mathrm{~mJ} / \mathrm{cm}^{2}$-es energiasürüség érte, amely egy nagyságrenddel az egylövéses ablációs küszöb $\left(170 \mathrm{~mJ} / \mathrm{cm}^{2}\right.$ [88]) alatt volt. A pumpaimpulzusokat egy hengerlencsével egy csíkba gyüjtöttem össze a minta felszínén, így egy $35 \mathrm{~mm} \times 0,7 \mathrm{~mm}$-es megvilágított területet kaptam. Ez a megvilágított területet átfedésben volt a próbaimpulzus elliptikus mérőfoltjával. A kísérleteim során a próbaimpulzusok beesési szöge $68,8^{\circ}$ volt. A nullellipszométer detektorkarjában elhelyezett kamera detektálta a minta felszínérő reflektálódó 
próbaimpulzusokat. A képeket számítógépes program rögzítette és dolgozta fel. Az általam kifejlesztett kiértékelési eljárást szintén az eredmények fejezetben részletezem.

\subsection{Mintakarakterizáció}

\subsubsection{Pásztázó elektronmikroszkópia és az elektronmikroszkópos képek kiértékelése}

Kísérleteim során létrehozott mintáim vizsgálatára az SZTE Természettudományi Karán található Hitachi S-4700 pásztázó elektronmikroszkópot használtam. A készülék kezelésében témavezetőm, Tóth Zsolt, valamint Füle Miklós segített. A képek rögzítése során az elektronok gyorsítófeszültségét a minta jellegétől függően 5-15 keV között, a nagyítás mértékét pedig 1000 és 20000-szeres értékek között változtattuk.

Doktori munkám során az egyik célom volt periodikus struktúrák létrehozása ultrarövid lézerimpulzusok segítségével, valamint azok tanulmányozása nagyfelbontású elektronmikroszkópos képek alapján. A nanométeres mérettartományba eső periodikus struktúrák tulajdonságai, mint például méretük vagy periodicitásuk, az elektronmikroszkópos felvételek alapján, direkt módon is meghatározható, azonban egy pontosabb lehetőséget teremt a képek Fourier-transzformációja, mely kvantitatív és kvalitatív módon képes jellemezni a struktúrák szabályosságát. A Fourier-transzformált képen a csomópontok helye megmutatja a struktúrák periódusának értékét, az alakja pedig a periodicitás minőségét. Minél pontszerübb egy csomópont annál szabályosabbak a struktúrák periodicitása.

Az 5. ábrán egy általam készített mintán mutatom be az elektronmikroszkópos képek gyors Fourier-transzformációval történő feldolgozását. Az elektronmikroszkópos képet az ImageJ nevü program segítségével dolgoztam fel. 
a)
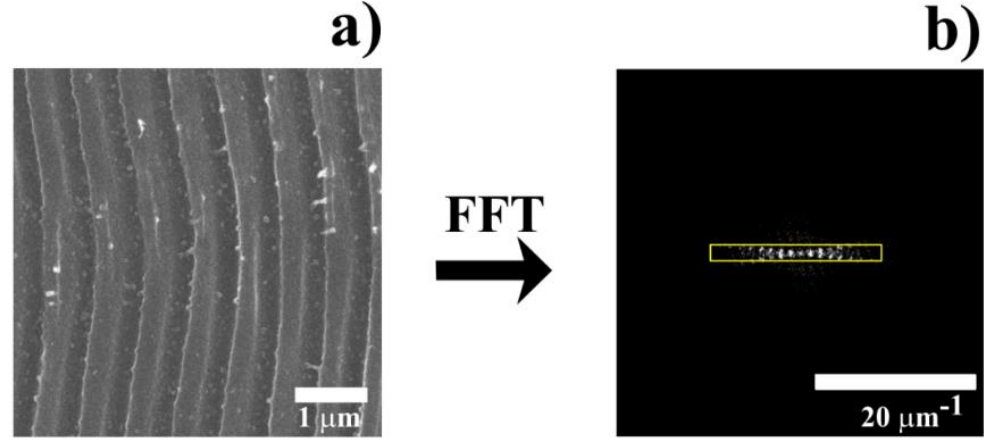

b)

$20 \mu \mathrm{m}^{-1}$

d)

Vonalmetszet
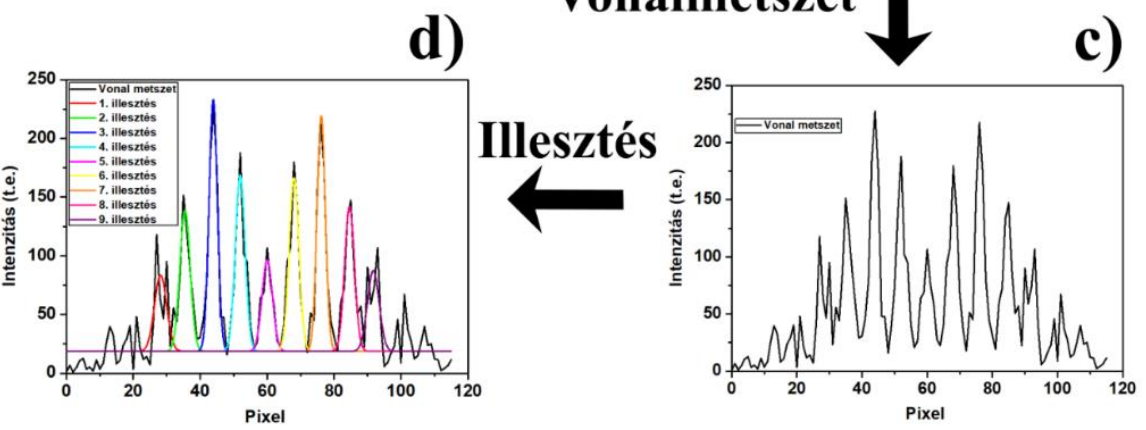

Pozíciók átszámolása távolság mértékegységbe

\begin{tabular}{|c|c|c|c|}
\hline Csúcs pozíció & Távolság pixelben & Átlag & Távolság um-ben \\
\hline 28.16 & $31.86^{\prime}$ & & : \\
\hline 35.45 & 24.57 & & i \\
\hline 43.9: & 16.12: & & $\mathrm{i}$ \\
\hline 51.93 & 8.09! & & \\
\hline 60.02 & i & & \\
\hline 68.02 & $8 \mathrm{i}$ & $8.045 i$ & 0.789712884 \\
\hline 76.13 & $16.111_{i}^{i}$ & 16.115 & 0.394243882 \\
\hline 84.62 & 24.6 & 24.585 & 0.258419368 \\
\hline 94.7: & 34.68 ; & & \\
\hline
\end{tabular}

5. ábra: a)Ti:Zafir lézerrel kezelt mintán létrejött periodikus struktúra elektronmikroszkópos képe, b) a SEM kép gyors Fourier-transzformáltja, c) a Fourier-transzformált képen felvett vonalmetszet, d) az intenzitásprofilra illesztett Gauss-görbék, e) az illesztésböl kinyert csúcs poziciók és az azokból számolt periódustávolság.

Periodikus struktúrák esetén a Fourier-transzformált kép középpontja, azaz a $0 \mu \mathrm{m}^{-1}$-hez tartozó érték körül kis kiterjedésü, kontrasztos, éles foltok mutatkoznak. A középponttól, azaz a nulladrendtől számított első folt az alap-, míg a többi folt ennek felharmonikusai. Az FFT kép középpontja mentén, vízszintesen vonalmetszetet vettem. Az így kapott intenzitásprofil (5. ábra c) része) segítségével határoztam meg a csomópontok középpontját a pozitív és a negatív 
térfrekvencia-tartományokon. A pontosság növelése végett a csúcsokra Gauss-görbéket illesztettem és az így kapott paraméterekből nyertem ki a csúcsok középpontjait. A maximumok helyzetét a képek nulladrendủ maximum pozíciójához képest számoltam ki, majd a pozitív és negatív térfrekvencia-tartományokon kapott értékek átlagát vettem. Ezt követően a pixel értékeket átszámoltam térfrekvenciába, amiből megkaptam a periodikus struktúrák térbeli periódushosszát.

\subsubsection{Raman-spektroszkópiai mérések}

Raman-spektroszkópiai méréseimet az SZTE Ásványtani, Geokémiai és Kőzettani Tanszékén végeztem egy Thermo Scientific cég által gyártott DXR Raman-mikroszkóp segítségével. Ez az eszköz egy konfokális mikroszkóppal egybeépített Raman-spektrográf. A mikroszkópban a minta lézeres gerjesztése felső megvilágításban történik. A gerjesztő lézerfény fókuszálása és a Raman-jel összegyüjtése ugyanazzal az objektívvel valósul meg, mely az adott modellben, $10 \times, 20 \times, 50 \times$ és $100 \times$-os nagyítású lehet. Méréseim során az 50×-es objektívet használtam, mellyel $\sim 2,5 \quad \mu^{2}$-es terület volt kivilágítva. A minta gerjesztésére két lézerhullámhossz használható ( $532 \mathrm{~nm}$ és $780 \mathrm{~nm}$ ). A disszertációmban bemutatott méréseimhez 532 nm-es hullámhosszú dióda pumpált szilárdtest-lézert használtam. A méréseim során a gerjesztő lézer teljesítményét alacsony értéknek, 1-3 mW között választottam meg, elkerülve így a felület felmelegítését, roncsolását. A méréseimhez használt integrálási idő jellemzően 20 másodperc volt. A zaj csökkentése céljából több, általában 3 spektrum átlagát vettem. A spektrográf kialakítása lehetővé teszi a spektrális bontóelem cserélhetőségét nagy felbontású és nagy spektrális tartományú rácsok között. Méréseim során a nagyobb spektrális tartományt biztosító rácsot használtam, mivel a szén módosulatok Raman-spektrumában nem csak a kisebb, de a nagyobb hullámszámok tartományában is detektálható jel, ami hasznos információt hordoz. Ezzel a ráccsal $5 \mathrm{~cm}^{-1}$ spektrális felbontás érhető el, 50 - $3500 \mathrm{~cm}^{-1}$ hullámszám-tartományon [89].

\subsubsection{Ellipszometria}

Spektrális ellipszometriai méréseimhez az SZTE Optikai és Kvantumelektronikai Tanszékén megtalálható, Woollam M2000-F típusú forgó kompenzátoros ellipszométert használtam. Az ellipszométer fényforrás karjában található egy $75 \mathrm{~W}$-os xenon lámpa, melynek kollimálását egy 
lencse végzi. A fényforrás- illetve a detektorkarban található egy-egy Glan-Thomson-féle prizma polarizátor, továbbá a fényforrás karban található egy pszeudo-akromatikus kompenzátor. Ezen optikai elemek forgatását egy léptetőmotor segítségével a számítógép vezérli. A fény beesési szögét $45^{\circ}$ és $90^{\circ}$ között lehet változtatni egy mikrométercsavar segítségével. A detektorkarba reflektálódó fény egy optikai szálon keresztül egy rácsos spektrográfba jut. A spektrálisan bontott fény detektálását egy CCD detektor végzi, mely a 245 nm-től 1000 nm-ig tartó tartományon, 470 pontban rögzíti a spektrumot.

Az ellipszometriai méréseim kiértékelésére többfajta ellipszometriai modellt használtam. Spektroszkópiai ellipszometriai mérések esetén az ismeretlen optikai adatok leírására leggyakrabban az ún. oszcillátor modelleket alkalmazzák. Ezek az oszcillátor modellek a dielektromos függvény képzetes részében $\left(\varepsilon_{2}\right)$ egy-egy abszorpciós sáv leírását teszik lehetővé, és a Kramers-Kronig-relációk révén a valós rész $\left(\varepsilon_{1}\right)$ jellemzésére is alkalmasak. A teljesség igénye nélkül a következőkben azokat a modelleket mutatom be, melyeket kutatásaim során is használtam.

Az első ilyen modell a Tauc-Lorentz-oszcillátor, amit leggyakrabban amorf anyagok dielektromos függvényének modellezésére használnak [90]. Az amorf anyagok esetében a dielektromos függvény képzetes része a tiltottsáv-szélességnek megfelelő fotonenergia környékén nem szimmetrikus. Ezt egy Tauc-féle sávéllel [91] és egy Lorentz-oszcillátorral lehet figyelembe venni, amit Tauc-Lorentz-modellnek neveznek [77]. Ilyen modell esetén a (21) összefüggés írja le a dielektromos függvény képzetes részét [77]:

$$
\begin{array}{cc}
\varepsilon_{2}(E)=\frac{A_{T L} E_{0} C_{T L}\left(E-E_{g}\right)^{2}}{\left(E^{2}-E_{0}^{2}\right)^{2}+C_{T L}^{2} E^{2}} \frac{1}{E} & \text { (ha } \left.E>E_{g}\right) \\
\varepsilon_{2}(E)=0, & \text { (ha } \left.E \leq E_{g}\right)
\end{array}
$$

ahol $E$ a fotonenergia, $E_{g}$ a Tauc-féle tiltottsáv-szélesség, $A_{T L}$ az oszcillátor amplitúdója, $E_{0}$ a pozíciója, $C_{T L}$ pedig a szélessége.

Amorf szén vizsgálata során gyakran használnak olyan modellt, melyben az abszorpciós sáv körül az $\varepsilon_{2}$ diszperzióját Gauss-függvény írja le. Ilyen modell esetén az $\varepsilon_{2}$ változását a (22)-es egyenlet adja meg [92]: 


$$
\varepsilon_{2}(E)=A_{G} e^{-\left(\frac{E-E_{0}}{\sigma}\right)^{2}}-A_{G} e^{-\left(\frac{E+E_{0}}{\sigma}\right)^{2}},
$$

ahol $\sigma=\frac{B_{G}}{2 \cdot \sqrt{l n 2}}$. Itt $A_{G}$ az oszcillátor amplitúdója, $E_{0}$ a pozíciója, $B_{G}$ pedig a szélessége.

Mindkét modell esetén $\varepsilon_{1}$ a Kramers-Kronig-integrálok segítségével kerül megadásra. Mivel az analitikusan elvégezhető integrálás eredményeként adódó formulák terjedelmesek, ezért ezek megadásától eltekintek, de az irodalomban [77,93] található róluk részletesebb leírás.

Fémek és félvezetők esetén az anyagban lévő, vagy gerjesztett szabad töltéshordozók könnyedén kölcsönhatnak a kis fotonenergiájú (infravörös) vizsgáló fénnyel, reflektálják, illetve abszorbeálják azt. Ez a folyamat meghatározza az anyag dielektromos függvényét, amit a Drudemodellel jól le lehet írni [77]:

$$
\varepsilon(E)=\varepsilon_{\infty}-\frac{\frac{\hbar^{2} e^{2} N}{\varepsilon_{0} m^{*}}}{E^{2}-i \frac{\hbar e}{m^{*} \mu} E} .
$$

Itt $\varepsilon_{\infty}$ a nagyfrekvenciás dielektromos állandó, $\hbar$ a redukált Planck-állandó, $e$ az elemi töltés, $N$ a szabad töltéshordozó koncentráció, $\varepsilon_{0}$ a vákuum dielektromos állandója, $m^{*}$ a töltéshordozó effektív tömege, $\mu$ pedig a mobilitása.

Gyakran a mérési eredmények modellezése során a dielektromos függvény diszperziójának leírásához nem elégendő egy modell alkalmazása. Ilyen esetekben több modellt szokás összegezni a diszperziós görbében jelentkező finomabb struktúrák pontosabb leírásához. Az eredményeim kiértékelésére használt konkrét modelleket az eredmények fejezetben ismertetem.

\subsubsection{Forgó kompenzátoros ellipszométer formulái}

Kísérleti során többször is használtam forgó kompenzátoros ellipszométert. Ilyen ellipszométer esetén a detektorba jutó fény intenzitásváltozását adott hullámhosszon a (24) képlet írja le.

$$
I(C)=K \cdot\left[A_{0}+A_{2} \cdot \cos (2 C)+B_{2} \sin (2 C)+A_{4} \cdot \cos (4 C)+B_{4} \sin (4 C)\right]
$$


Az összefüggésben szereplő $C$ paraméter a kompenzátor azimut szöge, $K$ egy intenzitástól függő szorzófaktor, az $A$ illetve $B$ paraméterek pedig az ún. Fourier-együtthatók. Ezek az együtthatók az alábbi módon függenek az ellipszometriai szögektől és az analizátor, illetve polarizátor azimut szögeitöl:

$$
\begin{gathered}
K \cdot A_{0}\left(x_{c} y_{c}, z_{c}, \Psi, \Delta, A, P\right)=1-\cos (2 A) \cdot \cos (2 \Psi) \\
+[\sin (2 A) \cdot \sin (2 P) \cdot \sin (2 \Psi) \cdot \cos (\Delta)+\cos (2 P) \cdot(\cos (2 A)-\cos (2 \Psi))] \cdot \frac{1+y_{c}}{2} \\
K \cdot A_{2}\left(x_{c} y_{c}, z_{c}, \Psi, \Delta, A, P\right)=-\sin (2 A) \cdot \sin (2 P) \cdot \sin (2 \Psi) \cdot \sin (\Delta) \cdot z_{c} \\
+[\cos (2 \Psi)-\cos (2 A)+\cos (2 P)(\cos (2 A) \cdot \cos (2 \Psi)-1)] \cdot x_{c} \\
K \cdot B_{2}\left(x_{c} y_{c}, z_{c}, \Psi, \Delta, A, P\right)=\sin (2 A) \cdot \cos (2 P) \cdot \sin (2 \Psi) \cdot \sin (\Delta) \cdot z_{c} \\
+[\sin (2 P) \cdot(\cos (2 A) \cdot \cos (2 \Psi)-1)-\sin (2 A) \cdot \sin (2 \Psi) \cdot \cos (\Delta)] \cdot x_{c} \\
K \cdot A_{4}\left(x_{c} y_{c}, z_{c}, \Psi, \Delta, A, P\right)=[\cos (2 P) \cdot(\cos (2 A)-\cos (2 \Psi)) \\
-\sin (2 A) \cdot \sin (2 P) \cdot \sin (2 \Psi) \cdot \cos (\Delta)] \frac{1-y_{c}}{2} \\
K \cdot B_{4}\left(x_{c} y_{c}, z_{c}, \Psi, \Delta, A, P\right)=[\sin (2 P) \cdot(\cos (2 A)-\cos (2 \Psi)) \\
+\sin (2 A) \cdot \cos (2 P) \cdot \sin (2 \Psi) \cdot \cos (\Delta)] \frac{1-y_{c}}{2}
\end{gathered}
$$

Az egyenletekben szereplő $x_{c}, y_{c}, z_{c}$ függvények az alábbi alakban írhatók:

$$
\begin{gathered}
x_{c}=\cos \left(2 \Psi_{c}\right) \\
y_{c}=\sin \left(2 \Psi_{c}\right) \cos \left(\Delta_{c}\right) \\
z_{c}=\sin \left(2 \Psi_{c}\right) \sin \left(\Delta_{c}\right)
\end{gathered}
$$

Ezekben az összefüggésben a kompenzátorra vonatkozó $\Psi_{c}$ és $\Delta_{c}$ adatok szerepelnek. Az adott hullámhosszon mért intenzitásváltozás illesztéséből kapott Fourier-együtthatók ismeretében kiszámolhatók az ellipszometriai szögek, vagy azok ismeretében, a kompenzátor $\Psi_{c}$ és $\Delta_{c}$ paraméterei. 


\section{Eredmények}

\subsection{Impulzuslézerekkel módosított felületü üvegszerü szén céltárgyak Raman- spektrumának kiértékelése}

A kutatásaim első részében különböző, impulzusüzemü lézerekkel kezeltem szilárdtest felületeket, és vizsgáltam a módosított felszínek tulajdonságait. A nagy teljesítménysürüségü impulzusok hatására extrém magas hőmérsékletek és nyomások alakulhatnak ki a minták felszínén. Az ultrarövid impulzusok alkalmazásával extrém felfütési sebességek mellett nagy lehülési sebességek is elérhetők, ami lehetővé teszi, hogy a folyamat során létrejövő kötésszerkezet a lehüléskor relaxáció nélkül szilárduljon meg. Így az ex-situ vizsgálatokkal a különböző állapotokban "befagyott" anyag szerkezete tanulmányozható. A bevezetőben is említettem, hogy teszt anyagként az üvegszerü szenet választottam. Egyrészt a szén magas olvadás- és forráspontja lehetővé teszi, hogy széles hőmérséklettartományban vizsgálhassam a szilárd és az olvadék állapot szerkezeti változásait, másrészt a szén esetében a kötésszerkezet vizsgálatára jó lehetőséget biztosít a rendelkezésre álló Raman-spektroszkópia. A különböző lézerekkel történő megmunkálás során változatos jellegű módosított felszínek alakultak ki, amelyeket spektroszkópiai ellipszometriai mérések segítségével is vizsgáltam. 


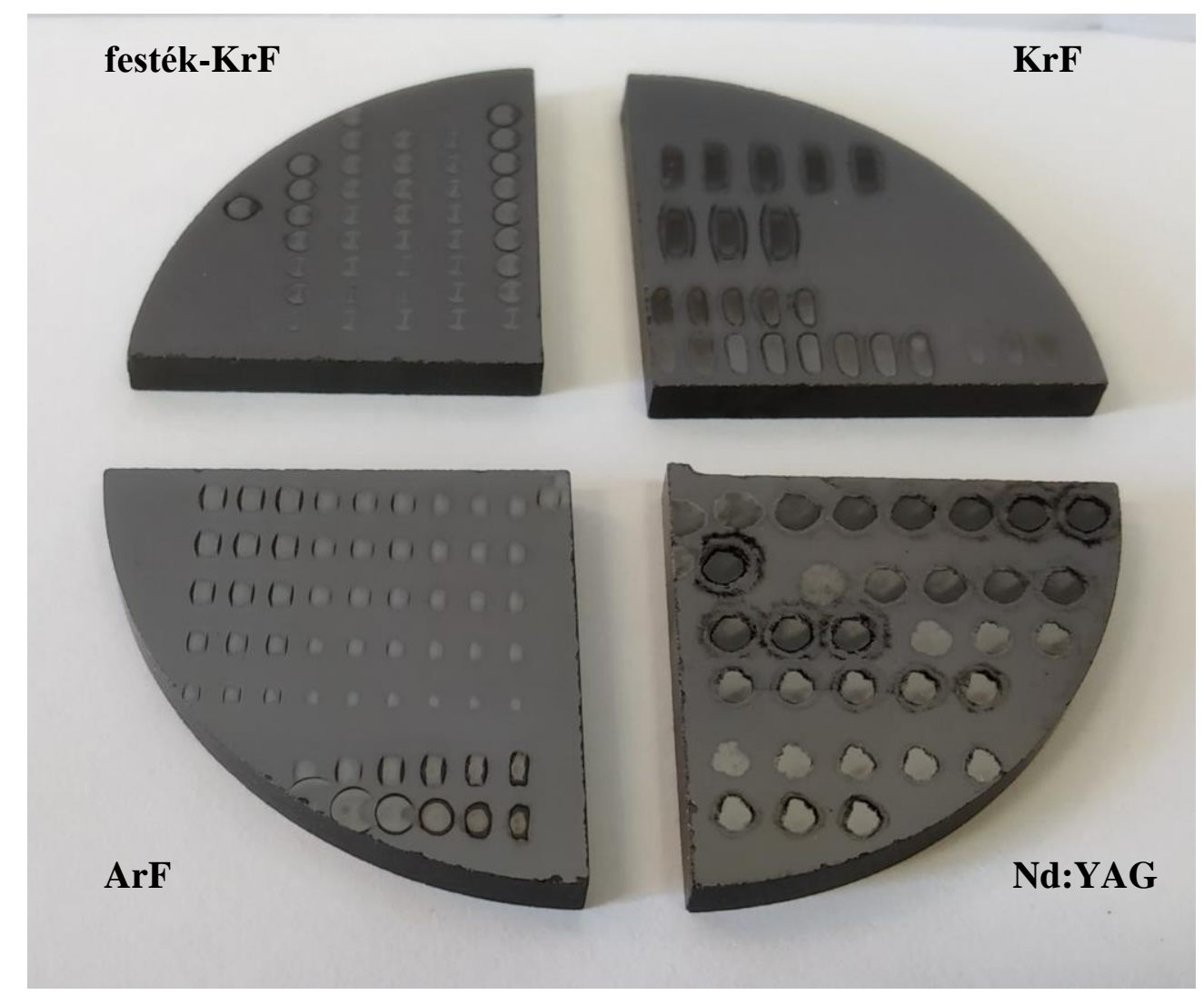

6. ábra: Fénykép a 4 fajta lézerrel módositott üvegszerü szén mintákról.

A 6. ábrán láthatóak a különböző lézerekkel megmunkált minták. A megmunkált területeken elvégzett spektroszkópiai ellipszometriai mérések eredményeit és a kiértékelés részleteit a következő fejezetben tárgyalom részletesen, azonban a mostani fejezet szempontjából egy lényeges eredményt szeretnék kiemelni. Az ellipszometriai vizsgálatok megmutatták, hogy a felszínen egy módosult réteg jelenik meg. Az ehhez a réteghez tartozó rétegvastagságokat, valamint a rétegekben a Raman-spektroszkópiai mérések során használt 532 nm-es hullámhosszúságú lézerfény behatolási mélységeit a III. táblázatban tüntettem fel. Az adatok alapján azt a megállapítást tettem, hogy a Raman-spektroszkópiai mérések során használt 532 nm-es hullámhosszúságú lézerfény behatolási mélysége (amit ezen a hullámhosszon meghatározott abszorpciós együttható reciprokaként definiálunk) legtöbbször nagyobb, mint a rétegvastagság. 


\begin{tabular}{|c|c|c|c|c|c|c|c|c|}
\hline \multirow[t]{3}{*}{ Minta szám } & \multicolumn{2}{|c|}{ Festék-Kr } & \multicolumn{2}{|c|}{ KrF } & \multicolumn{2}{|c|}{ ArF } & \multicolumn{2}{|c|}{ Nd:YAG } \\
\hline & $d$ & $1 / \alpha$ & $d$ & $1 / \alpha$ & $d$ & $1 / \alpha$ & $d$ & $1 / \alpha$ \\
\hline & \multicolumn{8}{|c|}{$[\mathrm{nm}]$} \\
\hline 1 & 18,5 & 50,9 & 13.8 & 43.2 & 6.7 & 25.5 & 34.4 & 86.4 \\
\hline 2 & 10,7 & 42,6 & 29.1 & 47.1 & 14.3 & 28.7 & 37.1 & 41.8 \\
\hline 3 & 8,9 & 42,9 & 28.1 & 75.8 & 15.5 & 28.5 & 66.5 & 27.7 \\
\hline 4 & 3,6 & 35,3 & 31.5 & 57.8 & 16.6 & 30.6 & 87.9 & 23.4 \\
\hline 5 & 2,3 & 38,6 & 33.3 & 65.3 & 19.6 & 31.2 & & \\
\hline 6 & & & 43.8 & 76.0 & 19.0 & 30.5 & & \\
\hline
\end{tabular}

III. táblázat: A módosult rétegek spektroszkópiai ellipszometriával meghatározott d vastagsága, és az $532 \mathrm{~nm}$ es fény 1/ $\alpha$ behatolási mélysége a módosult rétegben.

Ha a Raman-szórást gerjesztỏ lézer a módosított rétegnél is mélyebbre hatol, akkor a Ramanspektrumok a hordozó Raman-jelét is tartalmazzák. Az irodalomban lézerrel kezelt szilícium [94,95] és ittrium stabilizált cirkónium-oxid [96] felületeken is jeleztek ilyen effektust. Ilyen hatást figyelhetünk meg a 7. ábrán is, amelyen egy kezeletlen, valamint a kísérleteim során, festék- $\mathrm{KrF}$ lézerrel megmunkált üvegszerü szén Raman-spektrumát ábrázoltam. A kezeletlen üvegszerü szénen mért Raman-spektrumok az üvegszerü szénre jellemző keskeny G és D csúcsokat tartalmazzák. A lézerrel kezelt minta Raman-spektrumán jól látható, hogy az üvegszerủ szénre jellemző két, éles csúcs egy elkent, széles sávval kombinálódik. Ez az elkent sáv a felületen megjelenő réteghez köthető, és minden általam kezelt minta esetén megfigyelhető volt. 


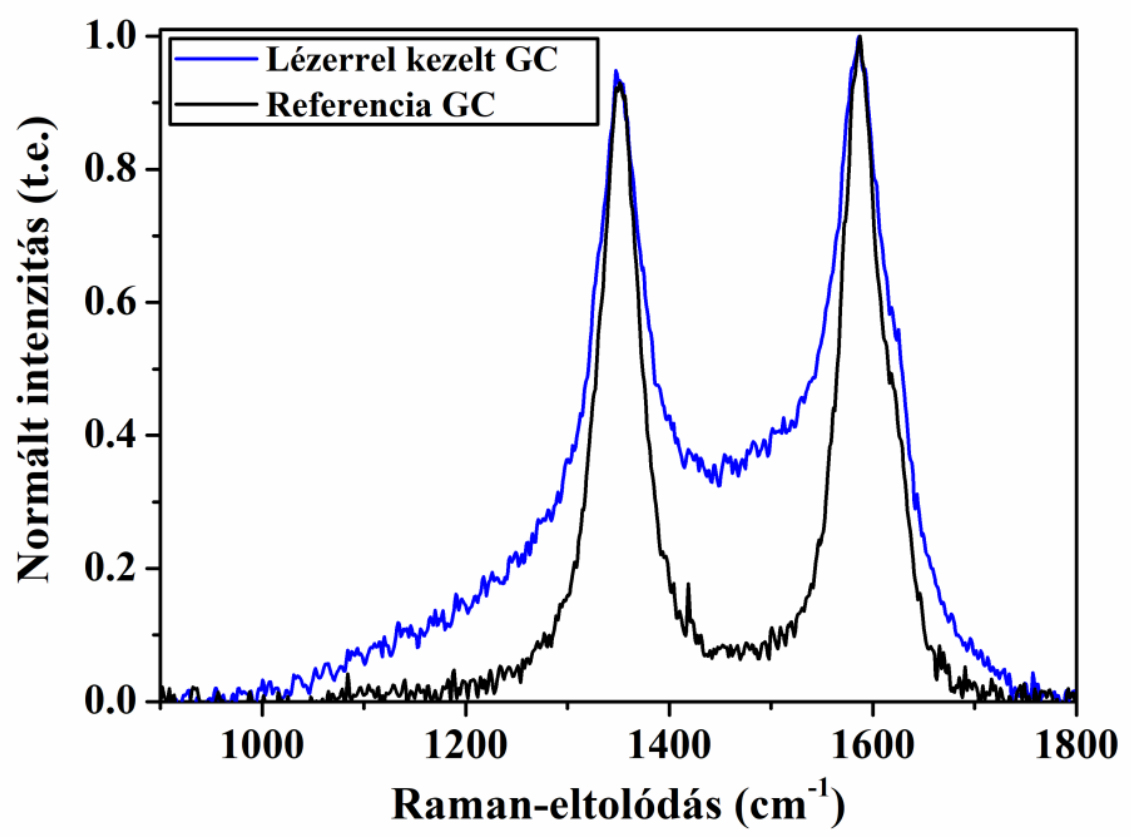

7. ábra: Üvegszerü szén (fekete görbe), valamint festék-KrF lézerrel módositott üvegszerü szén (kék görbe) Raman-spektruma.

Ahhoz, hogy a Raman-spektrumokból információt tudjak kapni a módosított felületi rétegre vonatkozólag, egy illesztési módszert dolgoztam ki, amely segítségével le tudtam választani a hordozó jelét a felületi módosított réteg spektrumáról. A következőkben összefoglalom ennek az illesztési eljárásnak a menetét, míg a módosított felületi réteg Raman-spektrumainak részletes elemzéséröl a következő alfejezetben számolok be. A GC és a rétegek Raman-spektrumainak szétválasztása céljából elsőnek a megmunkálatlan üvegszerủ szén Raman-spektrumát 3 Gaussfüggvénnyel illesztettem meg, melyek megfeleltek a D, G és D' csúcsoknak. Az illesztésből kapott függvényparamétereket a későbbiekben fix értékeknek vettem. A módosított rétegeken mért spektrumok kiértékelése során ezeket a függvényeket megszoroztam egy súlyfaktornak elnevezett változóval, melynek értéke 0 és 1 között változhatott. Ezzel a változóval vettem figyelembe a hordozó jelének gyengülését a kialakult réteg miatt. A módosított rétegből érkező Raman-spektrum kiszélesedett csúcsait további két Gauss-függvény bevezetésével vettem figyelembe, melyeket $\mathrm{D}^{\mathrm{m}}$, illetve $\mathrm{G}^{\mathrm{m}}$ betükombinációkkal jelöltem. A kiértékelések során ezeknek a függvényeknek a paraméterei, illetve a súlyfaktor volt az illesztési paraméter. A kiértékeléshez az Origin nevü programot (C) OriginLab Corporation, 2014) használtam. Az 8. ábrán tüntettem fel a különböző 
lézeres kezelésekhez tartozó egy-egy mért spektrumot, illetve az illesztési eljárással kapott eredményeket.

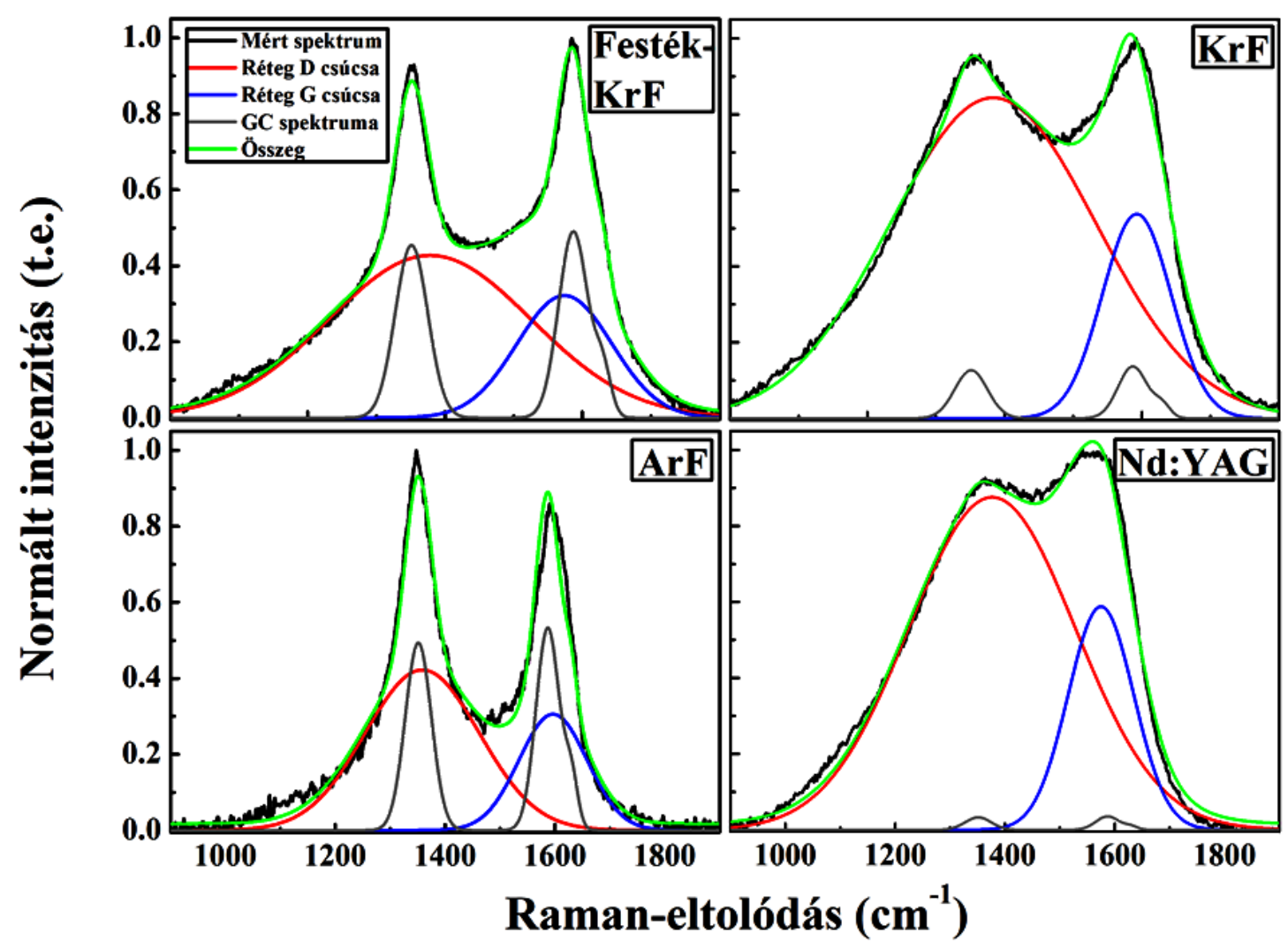

8. ábra: Egy lézerimpulzussal kezelt felületeken mért Raman spektrumok illesztése: A fekete görbe a mért Raman-spektrumot, a piros, illetve a kék a rétegre vonatkozó $D^{m}$ illetve $G^{m}$ csúcsokat mutatja. Szürkével a réteg alatt található üvegszerü szénre vonatkozó, súlyfaktorral korrigált Raman-jelet, zölddel pedig a görbék összegét jelöltem.

Ezt az eljárást mind a négy, lézeres kezelés során előállított minta sorra alkalmaztam. A kiértékelés során nagy szórást tapasztaltam alacsony lövésszámmal megmunkált minták esetén, így az alábbiakban csak a 15 lövéssel megmunkált mintákon kapott értékeket mutatom be. Az illesztésekből kapott súlyfaktor a hordozó Raman-jelének csökkenését írja le, így kapcsolatban áll a módosított réteg vastagságával és abszorpciós együtthatójával. Ezeket az adatokat az ellipszometriai méréseim alapján is meghatároztam, így a két független mérésből (Raman-szórás és ellipszometria) kapott adatsort össze tudtam vetni. A 9. ábrán az ellipszometriai mérésekből 
kapott rétegvastagság függvényében ábrázoltam a Raman-spektrumok illesztéseiböl kapott súlyfaktor értékeket. A súlyfaktor a rétegvastagság függvényében exponenciális jellegü függést mutat.

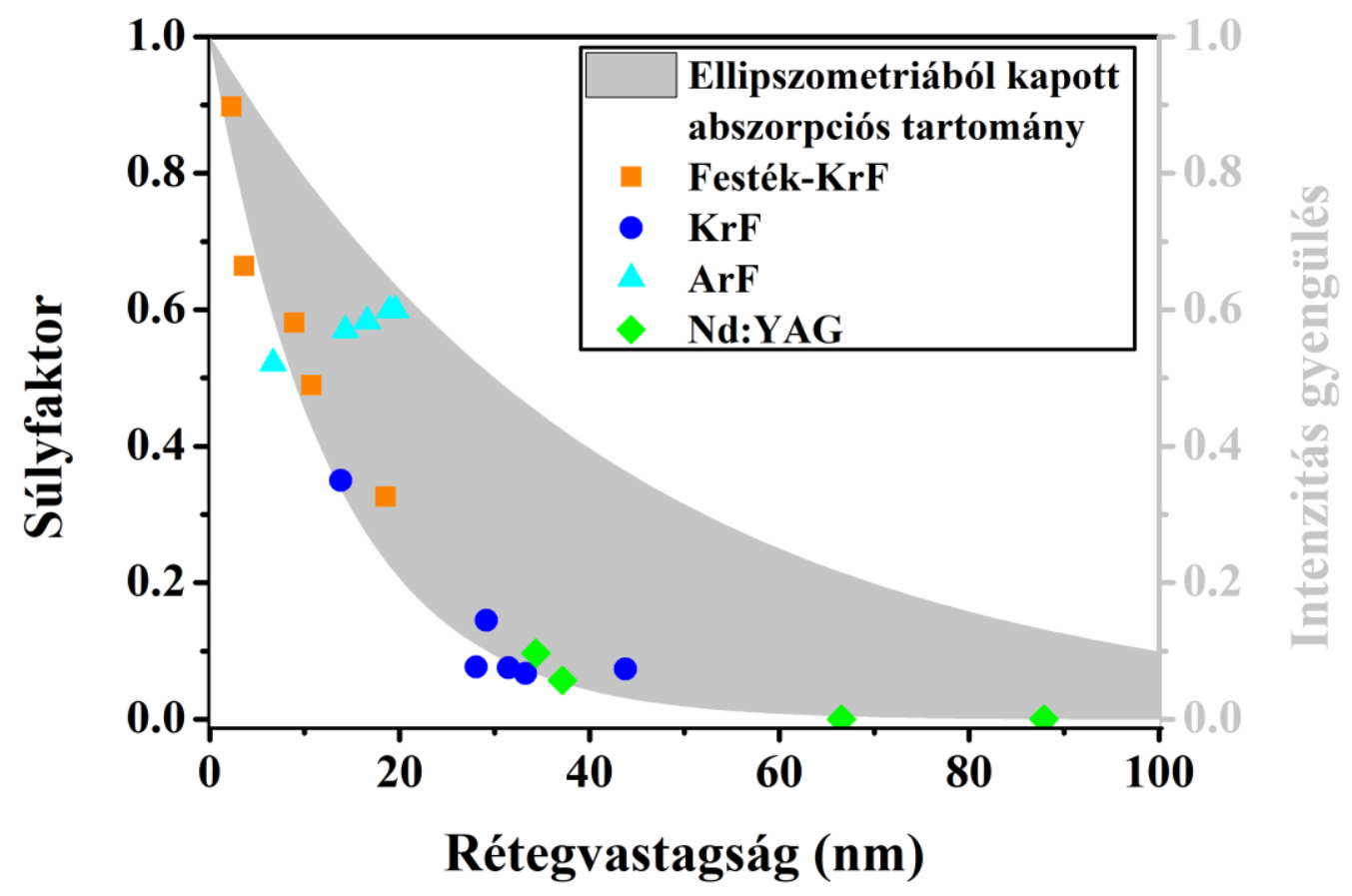

9. ábra: A 15 lövéssel kezelt minták (szimbólumok) Raman-spektrumainak illesztéséböl kapott súlyfaktor az ellipszometriai mérések kiértékeléséböl származó rétegvastagság függvényében. A szürke terület azt az egyre normált intenzitás gyengülési tartományt jelöli, amelyet a fény elszenved adott rétegvastagság esetén. Ezt a tartományt az ellipszometriai mérésekböl kapott legkisebb és legnagyobb abszorpciós együtthatók alapján határoztam meg.

Az exponenciális függés hátterében az áll, hogy a súlyfaktort az határozza meg, hogy a hordozó Raman-jele milyen mértékben járul hozzá a teljes Raman-spektrumhoz. Ezt viszont a hordozó Raman-jelének gyengülése szabja meg, azaz a módosult réteg abszorpciója / transzmissziója, melyet az exponenciális függvénnyel jellemezhető Beer-Lambert-törvény ír le. Ezt megerősítendő a minták ellipszometriai méréseiből kapott legkisebb és legnagyobb abszorpciós együtthatók segítségével meghatároztam a módosított rétegek egyre normált transzmissziós tartományát (9. ábra). Jól látható, hogy a Raman-spektroszkópiából és az ellipszometriából kapott eredmények átfednek, jó egyezést mutatnak. Így elmondható, hogy a 
súlyfaktor és a rétegvastagság közötti kapcsolat igazolja a Raman-spektroszkópiai mérések fent leírt módszerrel történő kiértékelésének helyességét.

A 9. ábrán látható, hogy az ArF lézerrel megmunkált minták esetén az illesztésből kapott súlyfaktor értékek nem illenek bele az exponenciális lecsengésbe, a rétegvastagsággal növekvő tendenciát mutatnak. Ennek okát a következő fejezetben bemutatásra kerülő ellipszometriai eredmények adták meg. Növekvő energiával történő megmunkálás a réteg vastagságának növekedését eredményezte, amit az ellipszometria jól jelez. Azonban a Raman-spektrumokból meghatározott súlyfaktor értékek nem csak a rétegvastagságtól, hanem az abszorpciótól is függnek. Ezeknél a mintáknál a növekvő energiával történő megmunkálás azt eredményezte, hogy a módosított réteg abszorpciója nagymértékben csökkent, aminek következtében a hordozó jele a rétegvastagság növekedésének ellenére is nőtt. Így a súlyfaktor értéke a rétegvastagság növekedésével nő, ami ellentétes a többi lézernél tapasztaltakkal.

Az ellipszometriai mérésekből kapott rétegvastagság, illetve abszorpciós tulajdonságok alapján az alábbi összefüggés segítségével kiszámolható, hogy az 532 nm-es gerjesztő lézer, valamint a réteg alatt lévő hordozóból származó 580 nm-es (a G csúcsnak megfelelő) hullámhosszú jel mekkora gyengülést szenved az abszorpció miatt:

$$
\frac{I}{I_{0}}=C_{\text {const }} \cdot e^{-\alpha_{532} \cdot d} \cdot e^{-\alpha_{580} \cdot d}
$$

Az összefüggésben $I_{0}$ jelöli a minta felszínét érő, $I$ pedig az azt elhagyó intenzitást. A réteg abszorpciós együtthatóit $532 \mathrm{~nm}$-en, illetve $580 \mathrm{~nm}$-en $\alpha_{532}$, illetve $\alpha_{580}$ jelöli, $d$ a réteg vastagsága, $C_{\text {const }}$ pedig a Raman-szórás hatásfokát leíró tényező. A 10 . ábrán jól látható, hogy az így számolt intenzitásgyengülés, és a Raman-spektrumok illesztése során kapott súlyfaktor közötti lineáris kapcsolat mutatkozik, mely szintén mutatja az illesztési eljárás helyességét. 


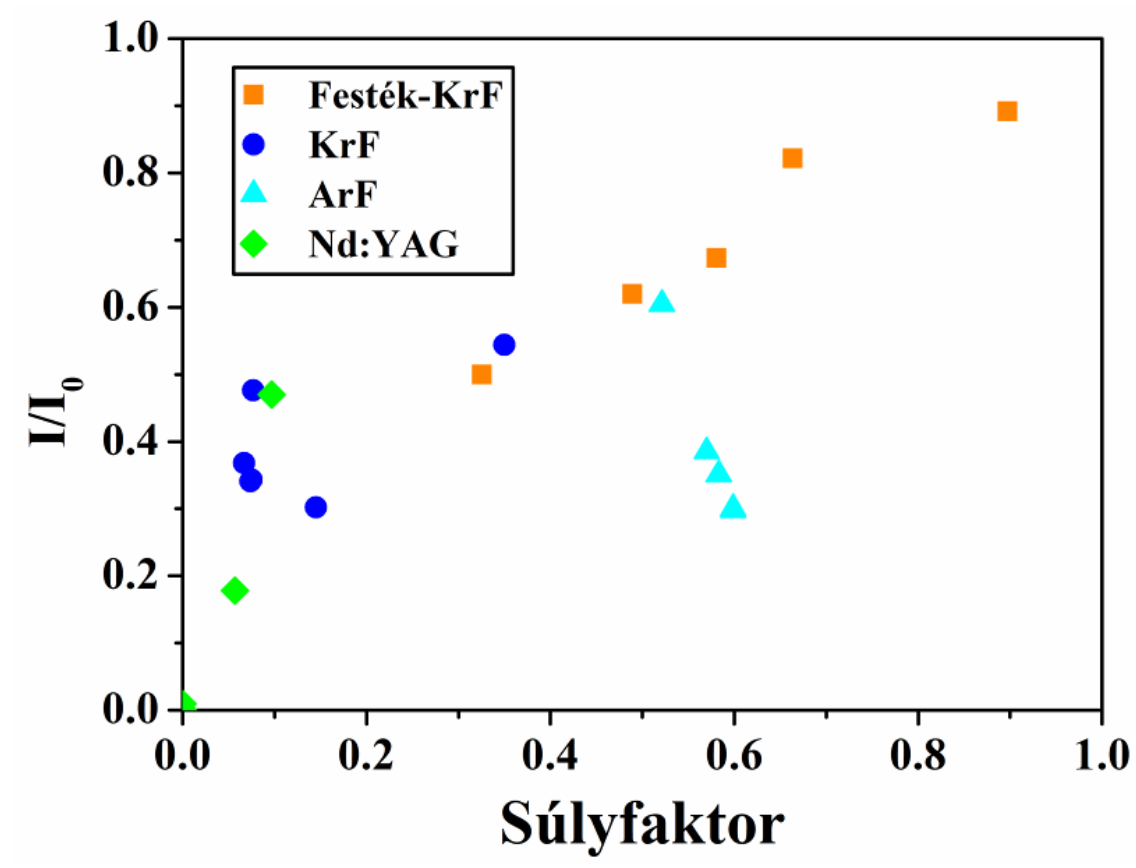

10. ábra: Az ellipszometriai mérésekből kapott rétegvastagság és abszorpciós tényezők alapján számolt intenzitás gyengülés a Raman-spektrumok illesztéséböl meghatározott súlyfaktor függvényében.

\subsubsection{A fejezethez tartozó tézisem}

T1: Kidolgoztam egy olyan kiértékelési módszert, amely lehetővé teszi, hogy hordozón lévő vékonyrétegek Raman-spektrumait olyan esetben is meg lehessen határozni, amikor a Ramanspektrumot a hordozó jele is terheli. Módszerem lényege, hogy a hordozóból származó Ramanjelet megfelelő modellezéssel szétválasztom a réteg jelétől. Eredményül a rétegre jellemző spektrum mellett egy a réteg vastagságára és abszorpciójára jellemző illesztési paramétert is kapok, melyet súlyfaktornak neveztem el. A kiértékelési eljárást különböző lézerekkel kezelt mintákon validáltam. Ehhez ellipszometriai méréseket végeztem, amelyből kapott abszorpciós értékek és rétegvastagságok a bevezetett súlyfaktorral egyértelmü korrelációt mutattak, alátámasztva az általam kidolgozott módszer helyességét. 


\subsection{Impulzuslézerekkel módosított üvegszerü szén ex-situ vizsgálata ellipszometriával és Raman-spektroszkópiával}

Ebben az alfejezetben az eltérő hullámhosszúságú és impulzushosszúságú lézerekkel kezelt üvegszerű szén felületén létrejövő struktúrák optikai és kötésszerkezeti tulajdonságainak vizsgálata során elért eredményeimet ismertetem.

\subsubsection{Ellipszometriai eredmények}

Kezeletlen és lézerimpulzusokkal megmunkált üvegszerü szén felületen spektroszkópiai ellipszometriai méréseket végeztem. Az ellipszometriai szögek spektrumait Woollam M2000-F ellipszométerrel, 300 nm - 1000 nm hullámhossztartományon mértem meg.

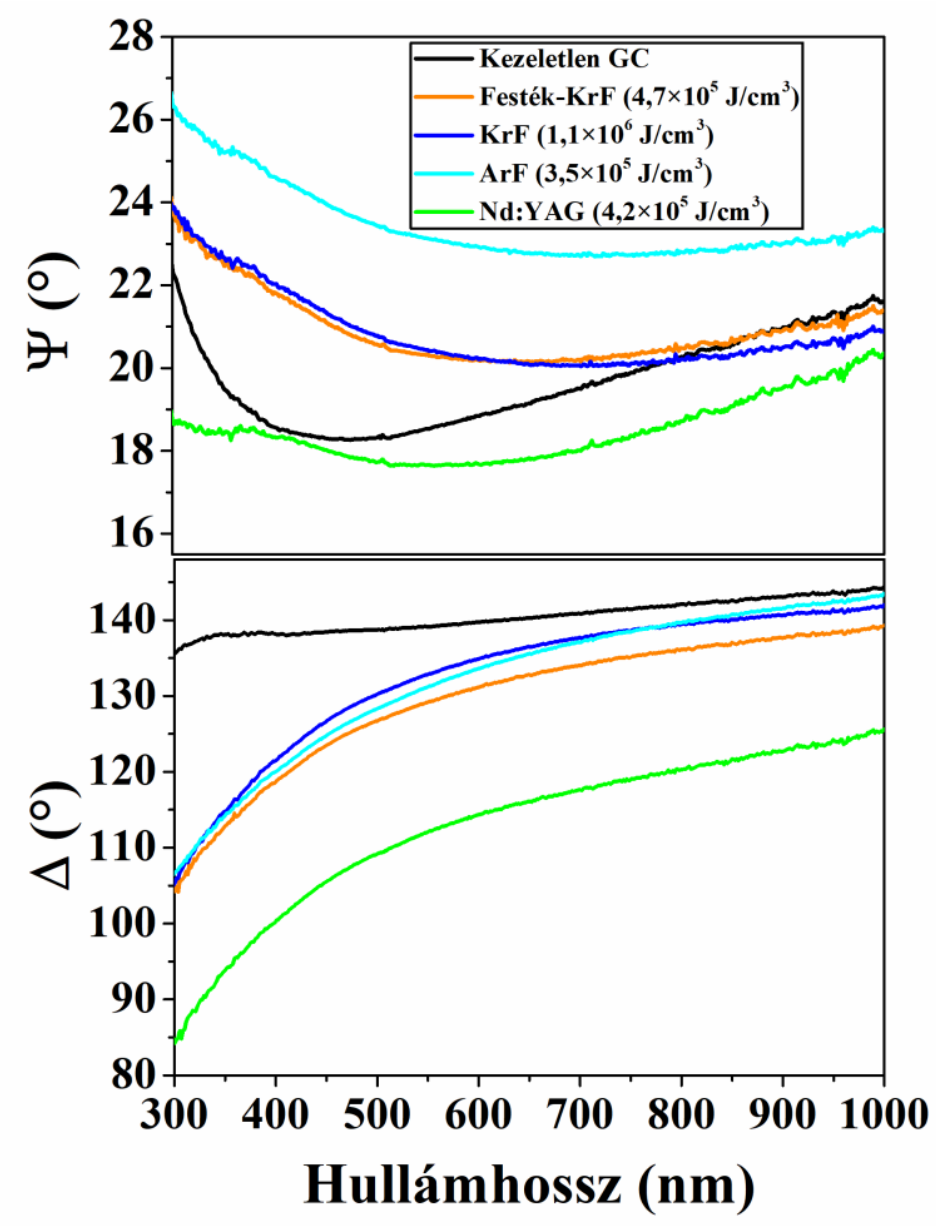

11. ábra: A kezelt és kezeletlen üvegszerü szén felületén mért ellipszometriai szögek a hullámhossz függvényében. 
Tipikus $\Psi$ és $\Delta$ spektrumokat mutat a 11 . ábra. A kezeletlen üvegszerü szén (GC) mellett négy, különböző lézerrel kezelt mintáról felvett spektrumokat tüntettem fel. Összehasonlítva az eredeti GC felületen mért $\Psi$ és $\Delta$ görbéket a megmunkált felületeken mértekkel, jól látható, hogy a görbék eltérnek, de jellegükben hasonlóságot mutatnak. Az eltérések arra utalnak, hogy a lézeres besugárzás egy módosított réteget eredményez a felszínen, azaz a hordozónak számító, tömbi GC felett egy módosított szén réteg található.

A kezeletlen GC felületen mért spektrumok kiértékelésére az általánosított oszcillátor modellt [93, 97] használtam. Az $\varepsilon_{2}$ spektrumot Gauss-, illetve Tauc-Lorentz-oszcillátorokból építettem fel. A modellből kapott törésmutató, illetve extinkciós együttható értékek a 12. ábrán láthatóak az irodalomban található értékekkel együtt [98, 99]. Megállapítható, hogy az irodalmi adatok lefutása hasonlít az általam mértekre, viszont szisztematikusan kisebb törésmutató, illetve extinkciós együttható értékek tartoznak az irodalmi adatsorokhoz. Ez azzal magyarázható, hogy az irodalmi értékek meghatározásánál más hőmérsékleten kezelt üvegszerü szenet használtak, ami esetén az eltérő porozitás, illetve sürüség okozhatja az általam tapasztalt eltérést.

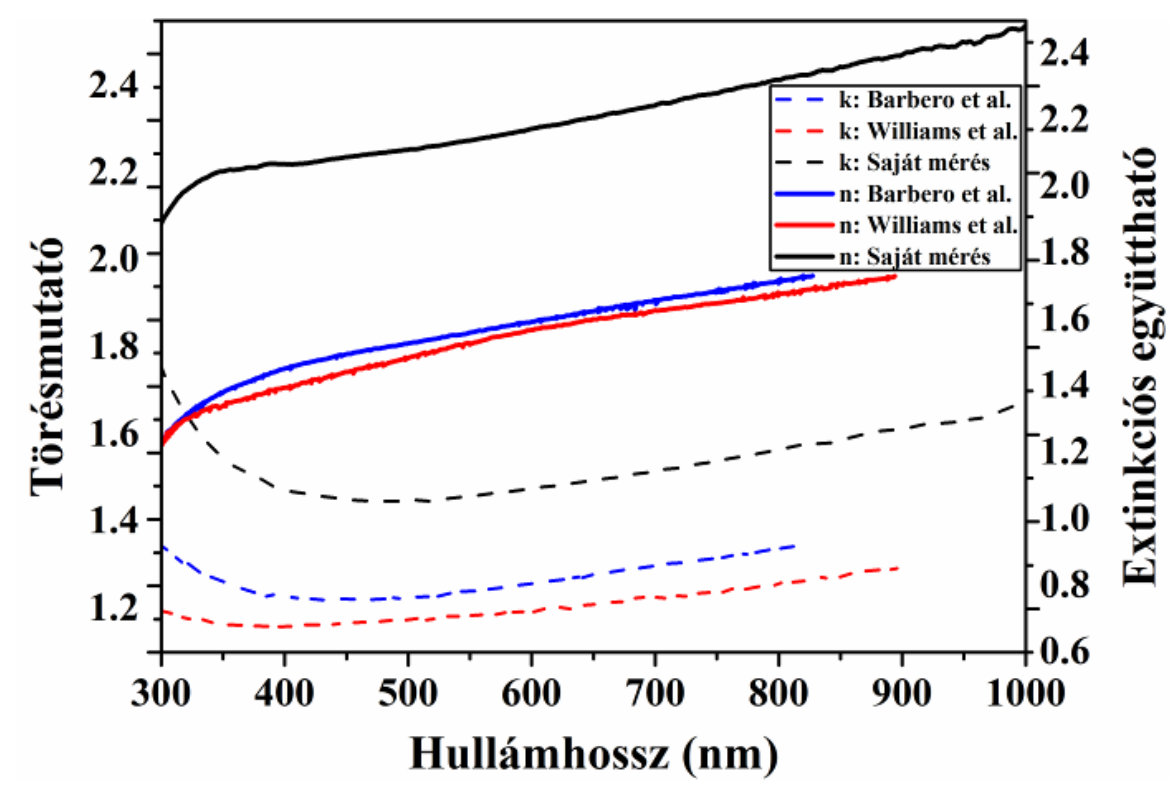

12. ábra: Üvegszerü szén törésmutatói (folytonos vonalak) és extinkciós együtthatói (szaggatott vonalak) a hullámhossz függvényében. Az ábrán feltüntettem a saját méréseim eredményeiböl származó értékek mellett az irodalomban fellelhető $n$ illetve $k$ értékeket is. 
A továbbiakban a megmunkálatlan üvegszerü szénnél kapott törésmutató és extinkciós együttható értékeket, mint a hordozó adatait, rögzített értékként kezeltem. Ehhez hozzáadtam egy réteget, amely modellezéséhez szintén Gauss-, illetve Tauc-Lorentz-oszcillátorokat használtam fel. Az ellipszometriai illesztés során a réteg kiinduló paraméterei a megmunkálatlan GC-re kapott értékek voltak. A 13. ábrán látható a modellezett rétegszerkezet. Ez a modell egy átlagos $n$ és $k$ értéket adott a módosított rétegre vonatkozóan. Bár nem nyújtott információt a réteg belső struktúrájáról, szerkezetéről, felületi érdességéről, azonban alkalmas volt a különböző lézeres kezelések során kialakult módosulatok összehasonlítására, és információt adott a rétegek vastagságáról.

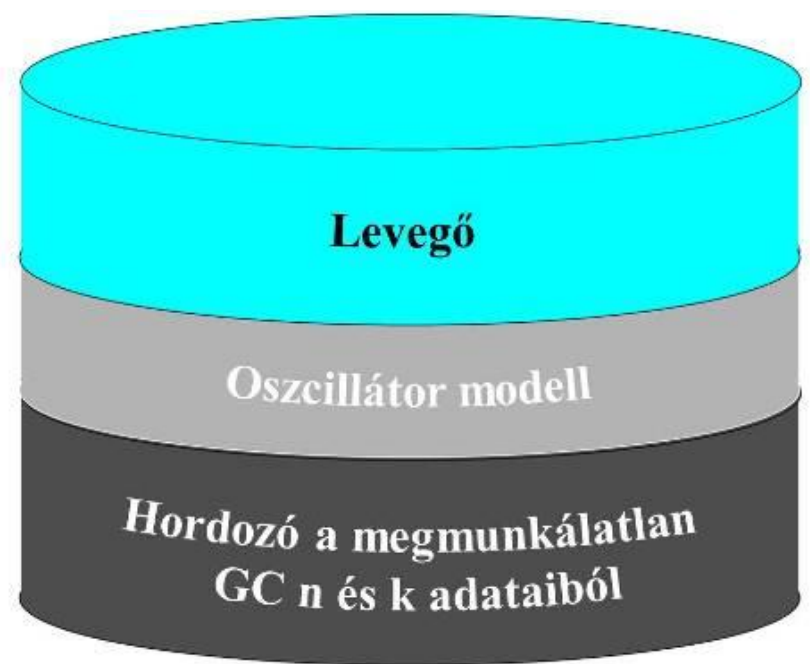

13. ábra: A használt ellipszometriai modell felépítése.

Az ellipszometriai modellből számolt spektrumok eltérését a mért eredményekhez képest az úgynevezett MSE érték jellemzi, amely egy átlagos négyzetes eltérés a modellből számolt és a mért ellipszometriai szögértékek között. Az illesztés annál jobbnak mondható, minél kisebb ez az érték. A modell, és a kapott eredmények helyességét jellemzi, hogy az MSE értékek, melyek a IV. táblázatban láthatók, jellemzően 10 alatti értéket vesznek fel. Ezek az értékek ilyen típusú minták esetén a tapasztalatok alapján jónak mondhatók. 


\begin{tabular}{ccccc}
\hline \hline Minta & Festék-KrF & KrF & ArF & Nd:YAG \\
\hline $\mathbf{1}$ & 3,739 & 8,819 & 3,447 & 9,081 \\
$\mathbf{2}$ & 8,646 & 9,384 & 7,405 & 6,747 \\
$\mathbf{3}$ & 6,629 & 5,465 & 7,618 & 6,199 \\
$\mathbf{4}$ & 4,829 & 6,79 & 11,69 & 7,146 \\
$\mathbf{5}$ & & 8,101 & 11,020 & \\
$\mathbf{6}$ & & 6,975 & 8,152 & \\
$\mathbf{7}$ & & 9,811 & 6,669 & \\
$\mathbf{8}$ & & 12,18 & 9,671 & \\
$\mathbf{9}$ & & 5,619 & & \\
$\mathbf{1 0}$ & & 6,210 & & \\
\hline \hline
\end{tabular}

IV.táblázat: A mért és a számolt adatok illeszkedését jellemzö MSE értékek az egy impulzussal megmunkált minták esetén.

A kiértékelést követően megvizsgáltam a $\Psi$ és $\Delta$ adatokból kapott törésmutatók és extinkciós együtthatók hullámhossz-függését. Az egyes lézeres kezelések esetén tapasztalt tipikus diszperziós görbék a 14. ábrán láthatók. Az ArF, a festék-KrF, valamint a Nd:YAG lézerekkel kezelt minták esetén csökkenő hullámhosszal csökkentő $k$ értékeket figyeltem meg. A KrF lézer esetén az $k$ értéke a hullámhosszal nem változott jelentősen. A törésmutató értéke a hullámhossz növelésével mind a négyfajta lézeres kezelés esetén növekvő tendenciát mutatott. A térfogati energiasürüség változtatásával a diszperziós görbéket megvizsgálva, mind az $n$, mind a $k$ értékében eltolódást tapasztaltam. Ennek az eltolódásnak a jellemzésére, valamint a mérési eredmények könnyebb értelmezése érdekében a törésmutatót és az extinkciós együtthatót egy adott hullámhosszon, 532 nm-en vizsgáltam. A hullámhossz ily módon történt megválasztásnak az volt az oka, hogy a Raman-spektroszkópiai mérések során használt gerjesztő lézer hullámhossza is ez volt. 

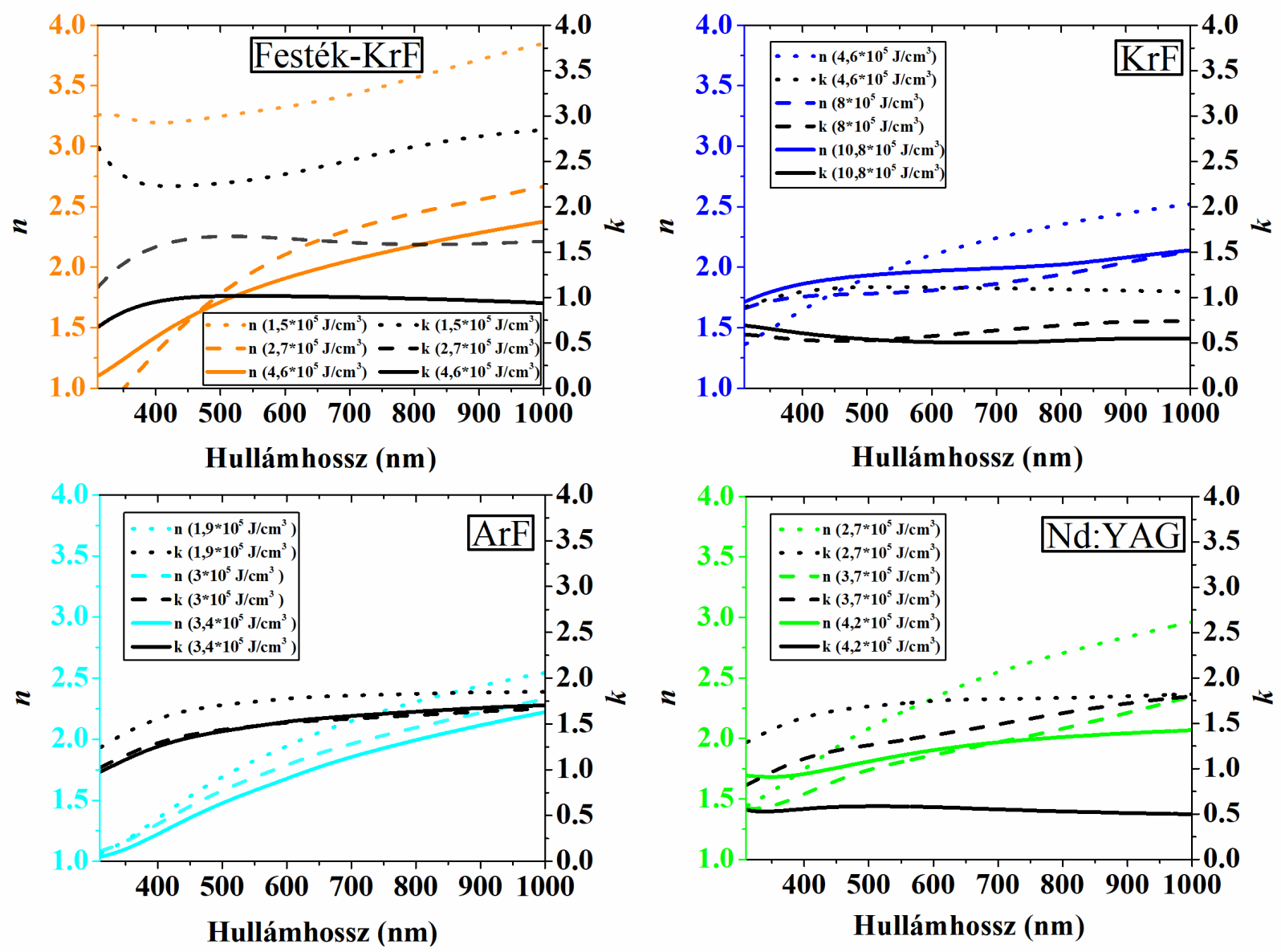

14. ábra: A különböző lézeres kezelések esetén egy impulzussal létrehozott, módositott réteg törésmutatója és extinkciós együtthatója a hullámhossz függvényében.

Az illesztésekből kapott, 532 nm-re vonatkozó törésmutató, extinkciós együttható, illetve rétegvastagság adatok a 15. ábrán láthatók a térfogati energiasürüség függvényében. Ahogy azt az 5.1.1 fejezetben is írtam, a megmunkáló impulzusok számát 1 és 20 között változtattam. Az eredmények ismertetését csak az 1, illetve a 15 lövéses minták esetén teszem meg, mivel hasonló tendenciát tapasztaltam a más impulzusszámmal megmunkált minták esetén is. 
1 lövés

15 lövés

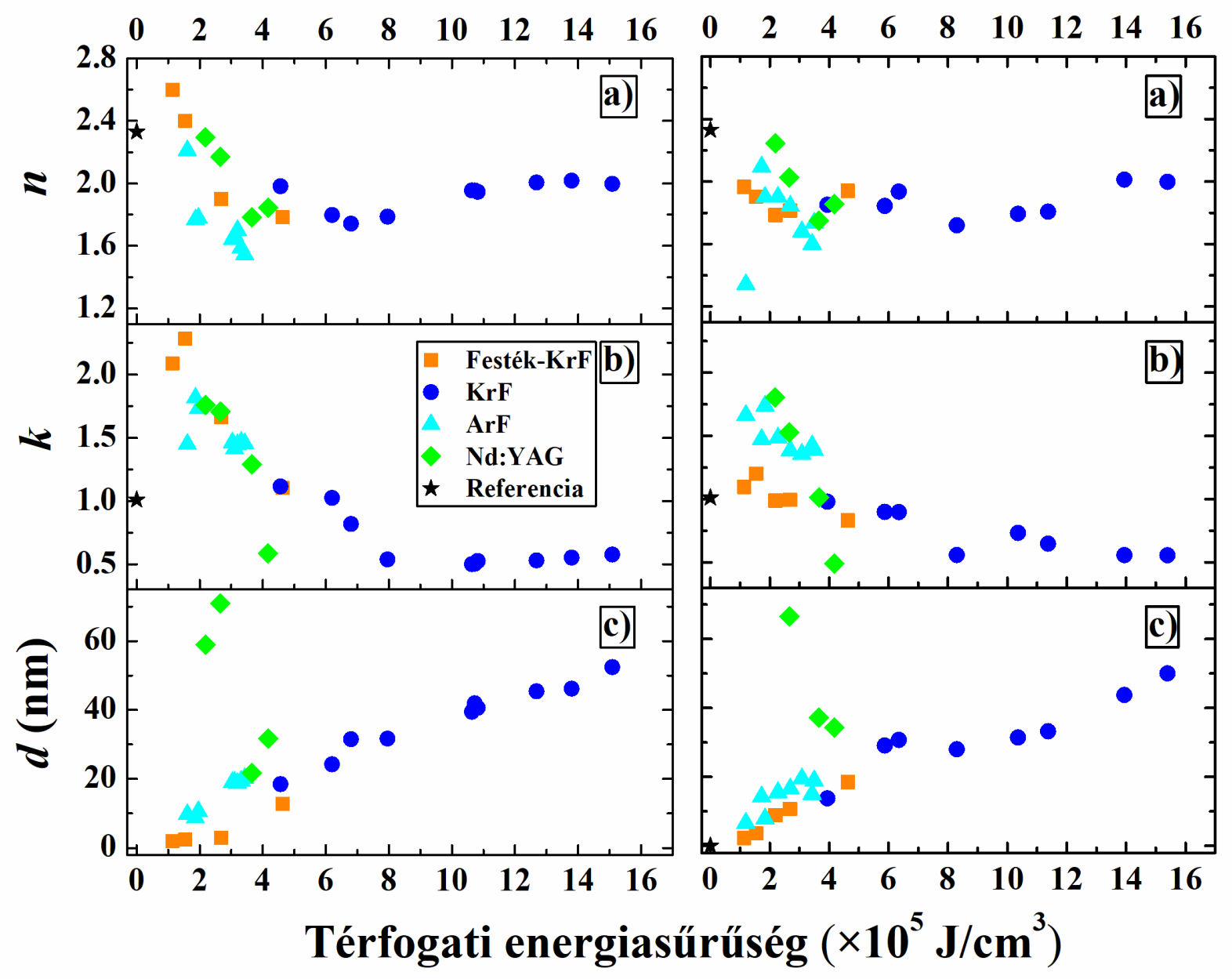

15. ábra: A különbözö lézeres kezelések által létrehozott módositott réteg a) törésmutató, b) extinkciós együttható és c) rétegvastagság adatai a térfogati energiasürüség függvényében, 1 valamint 15 impulzussal megmunkált minták esetén.

A kezelt felület $n$ és $k$ értékei alacsony térfogati energiasürüségek (TE) esetén veszik fel a legnagyobb értékeket. Ez az érték mindkét adatsor esetén a TE növelésével csökkenő tendenciát mutat, egészen $\sim 8 \times 10^{5} \mathrm{~J} / \mathrm{cm}^{3}$-ig. Az ezt meghaladó térfogati energiasürüségek esetén a törésmutató értékek enyhén növekednek, majd stabilizálódnak, az extinkciós együtthatók pedig hasonló, alacsony értéket vesznek fel. A kialakult rétegek vastagságában folyamatos növekedését figyeltem meg a TE növelésével. A paramétereket különböző megmunkáló lézerimpulzus-számok estén megvizsgálva hasonló tendenciákat mutattak. 
Fontos megjegyezni, hogy az ellipszometria kevésbé megbízható eredményeket szolgáltat a törésmutatóra és a rétegvastagságra egy időben, ha a meghatározni kívánt rétegvastagság $10 \mathrm{~nm}$ nél vékonyabb. Ilyen esetekben ugyanis - a rövid optikai úthossz miatt - a polarizációváltozáshoz csak kisebb mértékben járul hozzá az a tény, hogy a fény áthalad a rétegen. Így a mért ellipszometriai adatok kiértékelése során a rétegvastagság és az optikai adatok korreláltak lesznek. Ennek megfelelően a festék-KrF lézeres kezeléseknél a kis térfogati energiasürüséggel megmunkált mintáknál meghatározott $n$, illetve $k$ értékek nagyobb bizonytalansággal terheltek (lásd 15. ábra $1,5 \times 10^{5} \mathrm{~J} / \mathrm{cm}^{3}$ magas $n$ és $k$ értékeit).

A Nd:YAG lézerrel kezelt mintáknál a többi lézeres megmunkáláshoz képest a rétegvastagságok kiugróan magas értékeket vesznek fel, valamint a TE növelésével ellentétes, csökkenő tendenciát mutatnak. Ahhoz, hogy ezt az eltérést megértsük, figyelembe kell vennünk, hogy a különböző lézeres kezelések esetén a módosult réteg vastagságát a lézerimpulzusok behatolási mélysége, a gerjesztés módja, valamint a hődiffúziós és a fázisátalakulások folyamatai együttesen befolyásolják. A Nd:YAG lézer esetén tapasztalható kiugró rétegvastagság értékek magyarázhatók, ha figyelembe vesszük, hogy ennek a lézernek a legnagyobb a behatolási mélysége a GC-ben. A rétegvastagság ellentétes változása a többi lézerhez képest az eltérő ablációs folyamatokkal magyarázható. A Nd:YAG lézer estén a kis fotonenergia miatt kizárólag termikus gerjesztésen alapuló abláció valósul meg. Ilyen esetben a céltárgy felfütése és megolvasztása után, az olvadék elpárolgása okozza az anyag eltávozását, ami intenzívebbé válik, ha növeljük a térfogati energiasürüséget. Az excimer lézerek esetén a lézerimpulzusok fotonenergiája magasabb, ezért a fotokémiai kötésfelszakításon alapuló abláció nagyobb valószínűséggel megvalósulhat. Ez utóbbi folyamat csökkenti a behatolási mélységet, ezért az anyageltávozás mértéke is kisebb lesz.

Az ellipszometriai adatok alapján a következők állapíthatók meg a kötésszerkezetre vonatkozóan. A módosított rétegek $k$ értéke alacsony TE esetén nemcsak nagyobbnak adódott, mint a GC értéke, de jóval nagyobb a gyémántszerủ szén rétegere jellemző 0,45-os értéknél [100] is, ami az $\mathrm{sp}^{3}$-as hibrid kötések alacsony koncentrációját mutatja. A térfogati energiasürüség növekedésével a $k$ értéke csökken és nagy TE esetén megközelíti a 0,5 -es értéket. Ez jelenthetné a $\mathrm{sp}^{3}$-as kötések számának növekedését, azonban fontos megjegyezni, hogy hasonló csökkenést eredményezhet az abszorpcióban, ha a réteg porózussá válik. A porozitás ismeretének hiányában a fenti ellipszometriai kiértékelésből nem lehet egyértelmüen a kötésszerkezet jellegét meghatározni. 
A kötésszerkezettel kapcsolatos információim bővítése céljából a kezelt mintákon Ramanspektroszkópiai méréseket végeztem.

\subsubsection{Raman-spektroszkópiai eredmények}

A megmunkált felszíneken mért tipikus Raman-spektrumok normált görbéi a 16. ábrán láthatók.

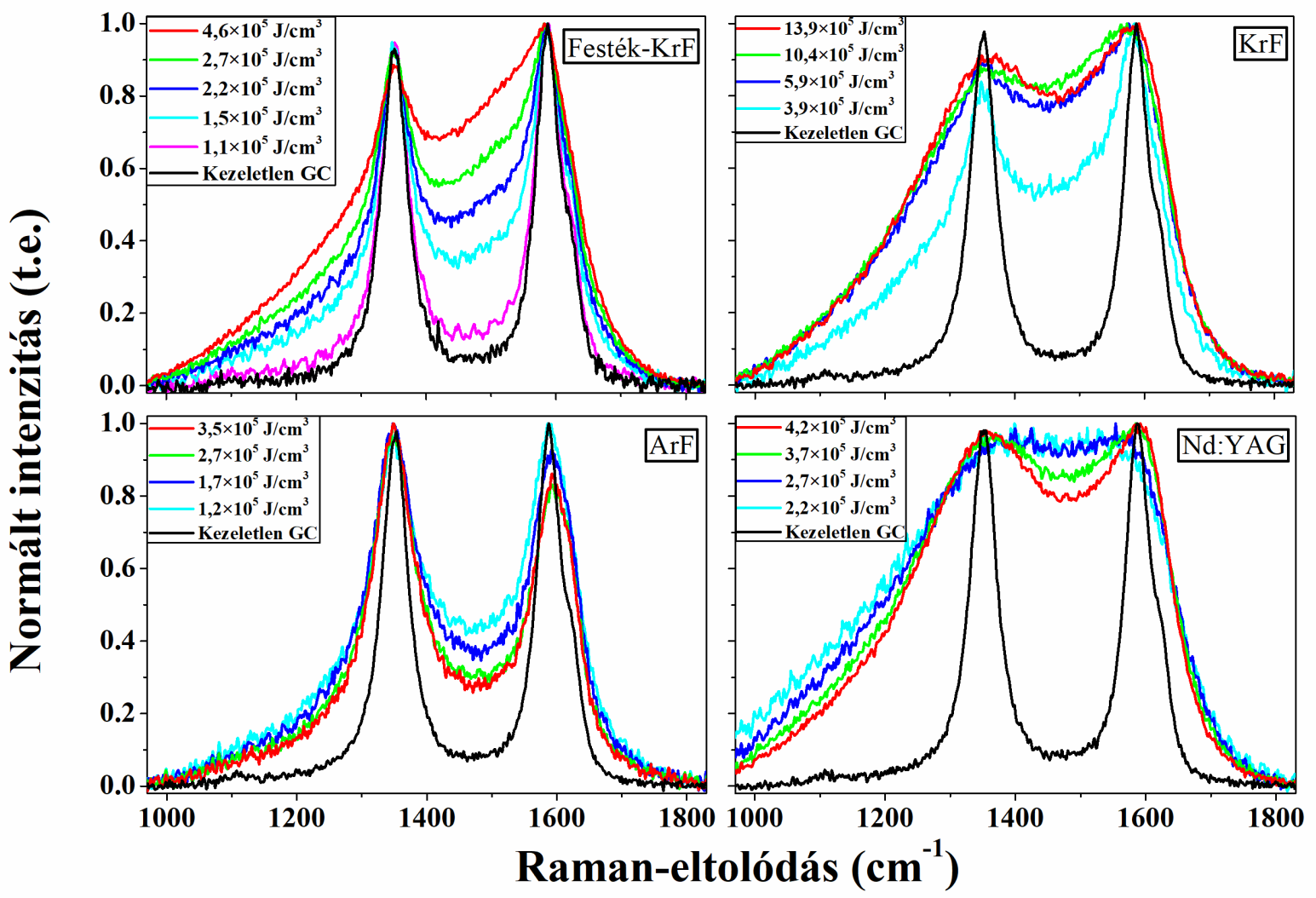

16. ábra: A különbözö lézerek esetén, egy impulzussal módositott felületek, normált Ramanspektrumai.

Ahogy azt a 7. ábránál bemutattam, a többi lézerrel kezelt minták esetén is a $D$ és $G$ csúcsoknak megfelelő hullámszámoknál egy kiszélesedett és egy élesebb csúcs kombinációja jelenik meg. Továbbá a spektrumokon jól látható, hogy nagyobb TE esetén az éles, hordozóra jellemző D és G csúcsok egyre kisebb intenzitással jelentkeznek. Ez összhangban van az ellipszometriai méréseimből kapott eredményekkel, ahol azt tapasztaltam, hogy a felületen 
megjelenő réteg vastagsága a térfogati energiasürüség növelésével növekszik (15. ábra c) része). Az ábrán jól látható, hogy a Nd:YAG lézerrel kezelt mintákon mért Raman-spektrumok nem mutatják a hordozó jelét. Ez szintén összhangban van az ellipszometriai mérések eredményével, ugyanis ebben az esetben a rétegvastagság $(70 \mathrm{~nm})$ nagyobb, mint a gerjesztő lézer behatolási mélysége $(\sim 30 \mathrm{~nm})$.

A 17. ábrán láthatóak a 6.1. fejezet alapján a mért adatokból kiszámolt, módosított rétegre vonatkozó Raman-spektrumok. A festék-KrF lézeres felületmódosítás esetén a legkisebb térfogati energiasürüséghez tartozó mérésből nem lehetett a módosított rétegre vonatkozó spektrumot megkapni. Jól látható, hogy az illesztett $\mathrm{D}$ és $\mathrm{G}$ csúcsok (amikre a továbbiakban $\mathrm{D}^{\mathrm{m}}$, illetve a $\mathrm{G}^{\mathrm{m}}$ csúcsokként hivatkozom) az üvegszerü szénnél szélesebbek, a két csúcs szinte összeolvad.

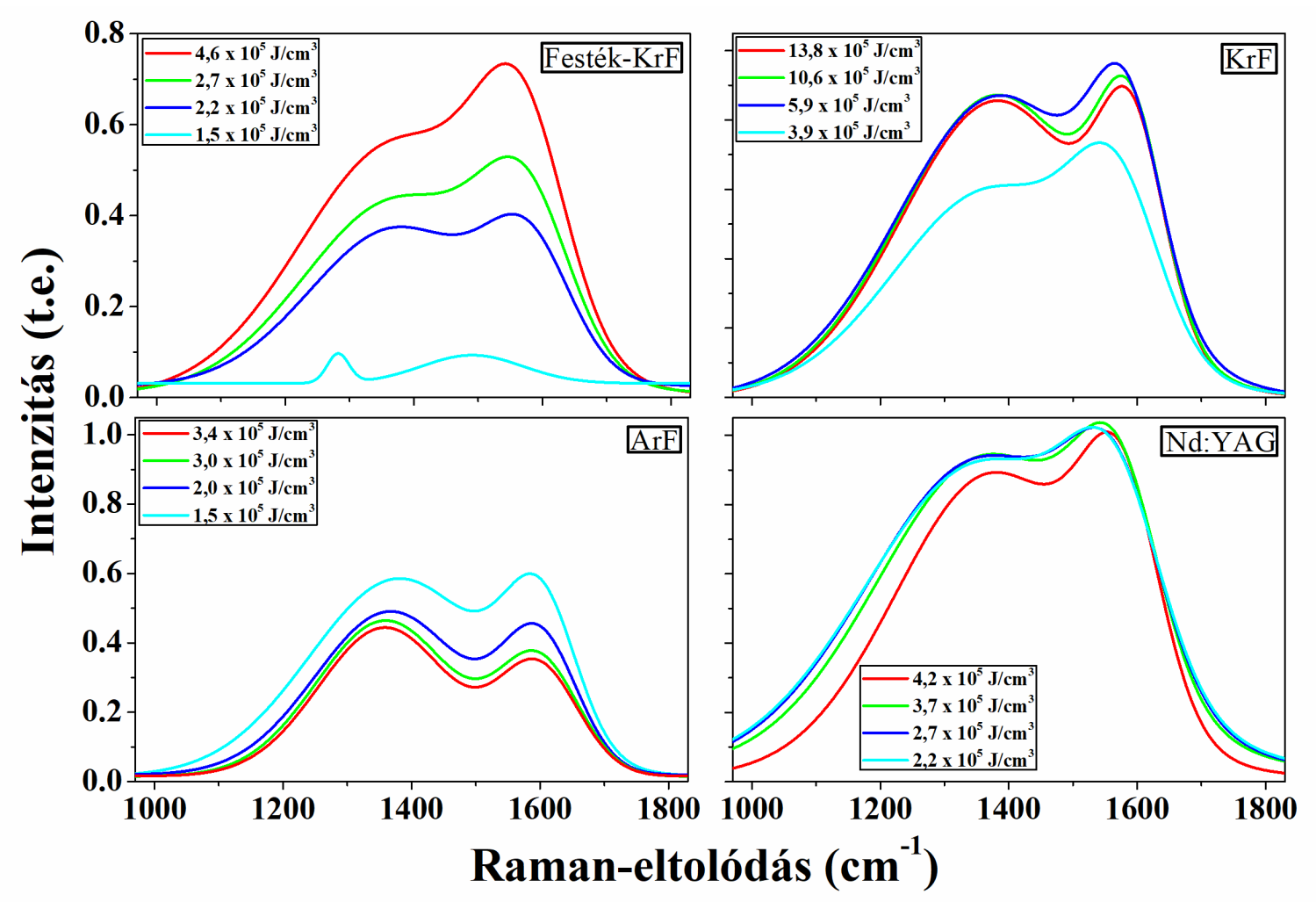

17. ábra: Az illesztésekböl kapott, a módositott rétegre vonatkozó Raman-spektrumok, egy impulzussal megmunkált minták esetén.

A módosított rétegekre vonatkozó Raman-spektrumokból könnyen meghatározható a $\mathrm{G}^{\mathrm{m}}$ csúcs pozíciója, a $\mathrm{D}^{\mathrm{m}}$ és a $\mathrm{G}^{\mathrm{m}}$ csúcs intenzitásaránya és a két csúcs félértékszélessége, amelyeket a 
szén módosulatok szerkezeti jellemzésére szokás használni [67]. Ezeket a paramétereket a térfogati energiasűrűség függvényében vizsgáltam, és a kapott eredményeket az 1 illetve 15 lövésszámok esetén a 18. ábrán tüntettem fel.

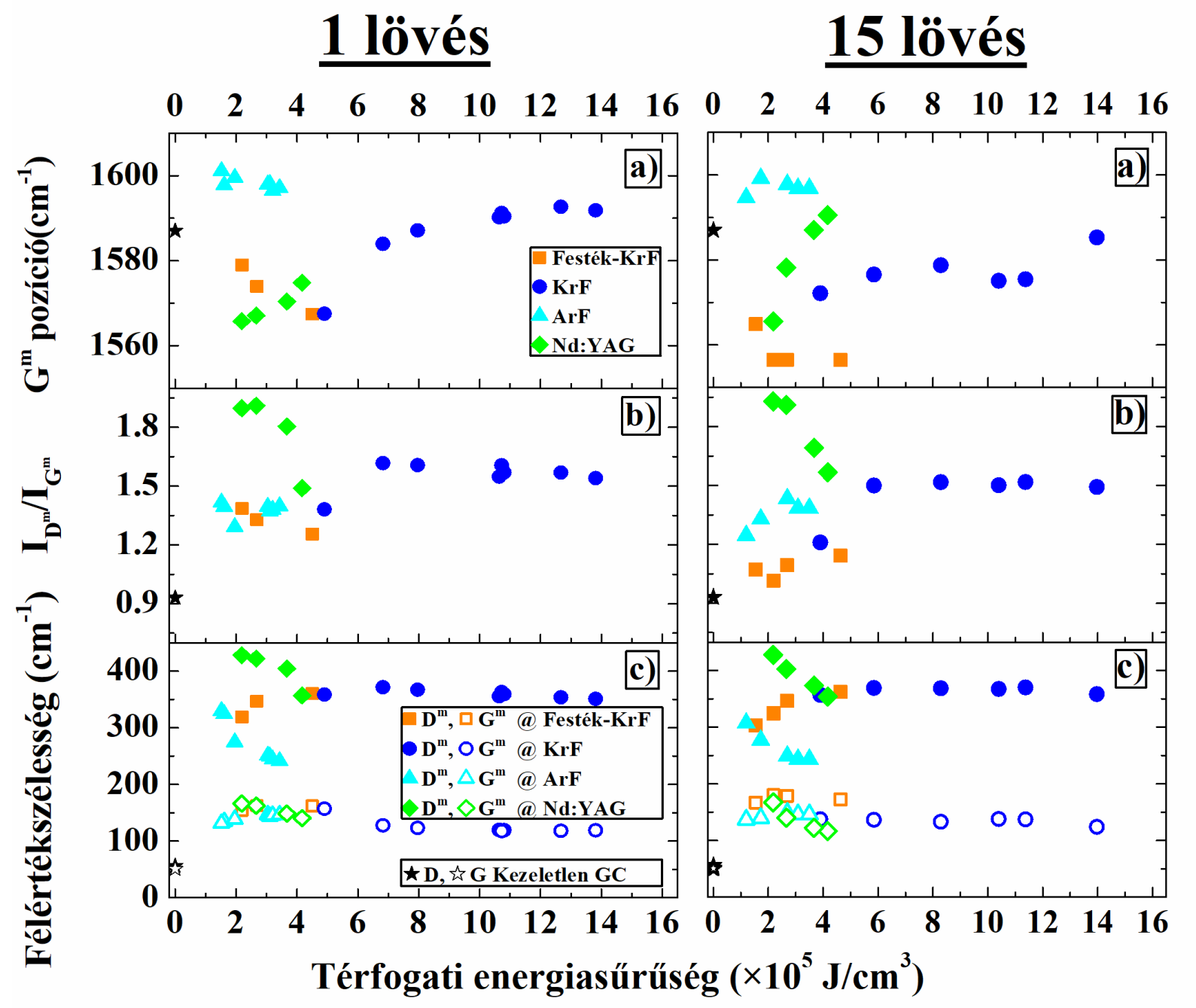

18. ábra: a) a módosított rétegek Raman-spektrumaiból meghatározott $G^{m}$ csúcs pozíciója, b) a $D^{m}$ és a $G^{m}$ csúcs intenzitás aránya és c) a félértékszélességük a térfogati energiasürüség függvényében 1, illetve 15 lövéses minták esetén.

Az üvegszerü szénre jellemző $G$ csúcs pozícióját, a két csúcs intenzitásarányát és félértékszélességüket fekete csillaggal ábrázoltam $0 \mathrm{~J} / \mathrm{cm}^{3}$ értéknél, hogy követhetők legyenek a lézeres kezelés okozta változások. Az egyes lézerek esetén a $\mathrm{G}^{\mathrm{m}}$ csúcs pozíciója a különböző lövésszámoknál hasonló tendenciát mutat. Az ArF lézer kivételével az összes lézeres felület 
megmunkálás esetén a $\mathrm{G}^{\mathrm{m}}$ csúcs pozíciója alacsony térfogati energiasűrüségeknél kisebb értéket vett fel, mint a referencia érték. A TE növelésével a nagyobb hullámszámok felé történő eltolódását figyeltem meg. A kivételt képező ArF lézer esetén a csúcs pozíciója $1600 \mathrm{~cm}^{-1}$, és nem változik a TE növelésével. A KrF és a $\mathrm{Nd}$ :YAG lézerekkel megmunkált minták esetén a csúcs pozíciója folyamatosan eltolódik a nagyobb relatív hullámszámok felé a térfogati energiasűrüség növelésével. A festék-KrF lézeres kísérletek eredményeként a csúcs pozíciójának változásában ellentétes tendencia figyelhető meg, kisebb relatív hullámszámok felé tolódott el, növekvő térfogati energiasürüséggel.

A $D^{\mathrm{m}}$ és $\mathrm{G}^{\mathrm{m}}$ csúcsok aránya (18. b) ábra) mindegyik lézeres kezelés eredményeként függetlenül az impulzusszámtól - nagyobb értékeket vesznek fel az eredeti, 0,9-es arányhoz képest. A Nd:YAG lézeres megmunkálás esetén ez az arány a legkisebb TE esetén veszi fel a legnagyobb értéket, majd csökkenését mutat a térfogati energiasürüség növelésével. A többi lézer esetén alacsony térfogati energiasürüségeknél növekvő tendenciát figyeltem meg az arányban, ami $6 \times 10^{5} \mathrm{~J} / \mathrm{cm}^{3}$ felett telítődő jelleget mutat.

A csúcsok félértékszélességét vizsgálva azt tapasztaltam, hogy azok mind a négy lézeres megmunkálás hatására kiszélesednek, a csúcsok kiszélesedésének mértéke azonban nem azonos: a $\mathrm{D}^{\mathrm{m}}$ csúcs a $\mathrm{G}^{\mathrm{m}}$-nél nagyobb félértékszélességgel jellemezhető. A térfogati energiasűrüség változásával a $\mathrm{G}^{\mathrm{m}}$ csúcs félértékszélességében nem figyeltem meg számottevő változást. $\mathrm{A} \mathrm{D}^{\mathrm{m}}$ csúcs félértkészélessége a $\mathrm{KrF}$ és festék-KrF lézeres kezelés esetén nem változik számottevően a TE növelésével, viszont az ArF valamint a Nd:YAG lézerek esetén növekvő TE értékekkel csökkenő tendencia mutatkozik. Összességében a $D^{m}$ és $G^{m}$ csúcsok félértékszélessége alapján elmondható, hogy a megmunkált felületi rétegek az üvegszerü szénhez képest kristálytanilag rendezetlenebb struktúrát mutatnak. 


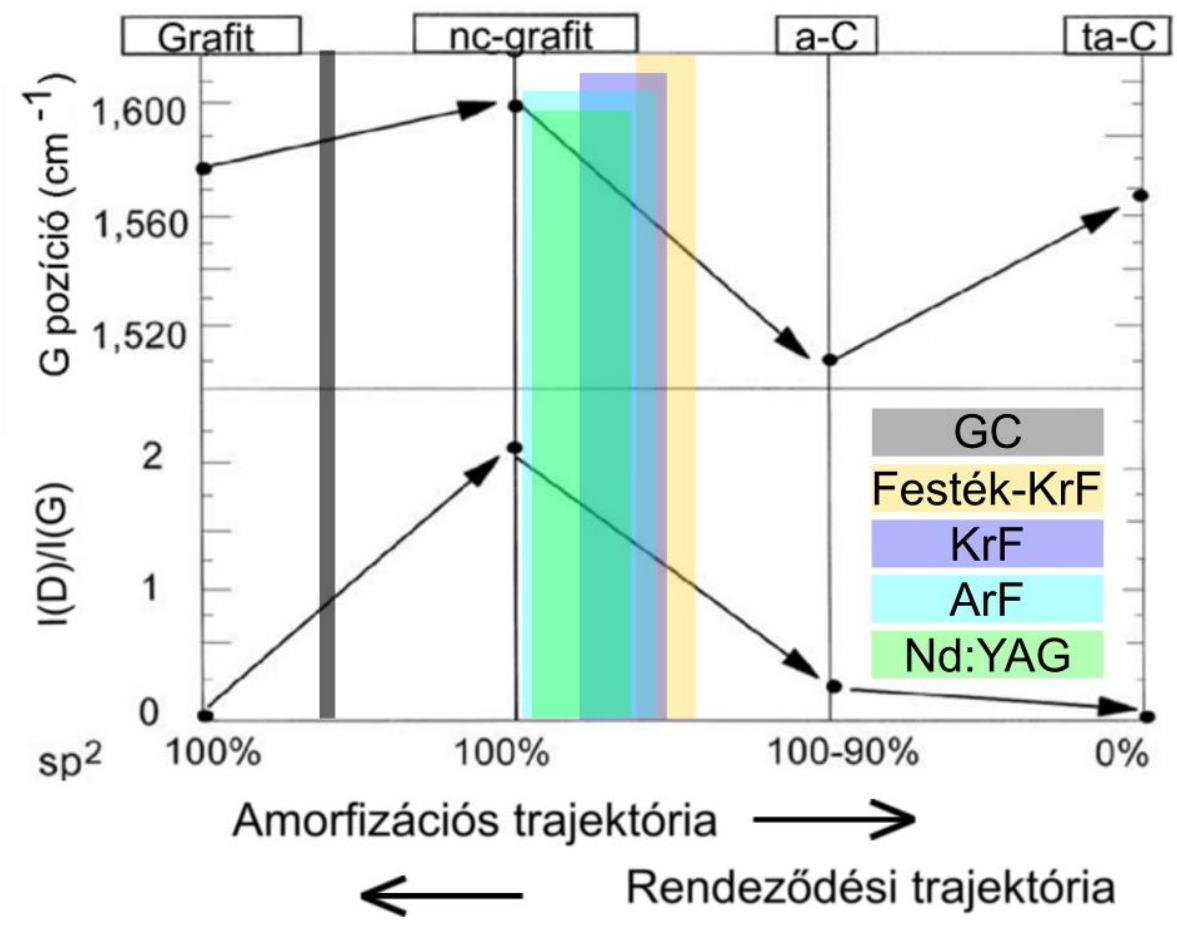

19. ábra: A 3 fázisú modellen feltüntetett lézeres felületmódositások eredményei. A szines sávokat a Raman-spektrumok kiértékelése során kapott G csúcseltolódás-intenzitásarány értékpárok alapján rajzoltam be.

A módosított rétegre jellemző $\mathrm{G}^{\mathrm{m}}$ csúcs pozíciója, valamint a csúcsok intenzitásaránya alapján a megmunkálás hatására bekövetkező szerkezeti változásokat a háromfázisú modell (3.2.2.1. fejezet) segítségével követhetjük nyomon. A 3 fázisú modellt reprezentáló ábrába (19. ábra) színes sávként bejelöltem a kezeletlen üvegszerü szén, valamint a különböző lézeres kezelések eredményeit. A csúcseltolódás-intenzitásarány értékpárok alapján a lézeres kezeléssel létrehozott módosított réteg kötésszerkezete az amorfizáció irányába tolódott el (ezt már a kiszélesedő csúcsokból is egyértelmủen láthattuk), azonban közelebb áll a nanokristályos grafit állapotához, mint az amorf szénhez. Továbbá az is megállapítható a modell alapján, hogy nem jelennek meg sp ${ }^{3}$-as hibridizált kötések a felületi módosítás nyomán. A térfogati energiasürüség függvényében vizsgálva a szerkezeti változásokat, nem tapasztaltam egyértelmü tendenciát. A módosított felületeken mért Raman-spektrumok további elemzésekor hasonlóságot véltem felfedezni a szén nanorészecskéken mért spektrumokhoz képest [41]. Ezek az eredmények a 
felületen nanorészecskék megjelenését sejtetik. A nanorészecskék megjelenésének igazolása céljából elektronmikroszkópos méréseket végeztem témavezetőm segítségével.

\subsubsection{Az elektronmikroszkópos, az ellipszometriai és a Raman-spektroszkópiai eredmények összehasonlítása}

A lézeres kezelések okozta morfológiai változások nyomon követése céljából készült elektronmikroszkópos képek a 20. ábrán láthatóak.

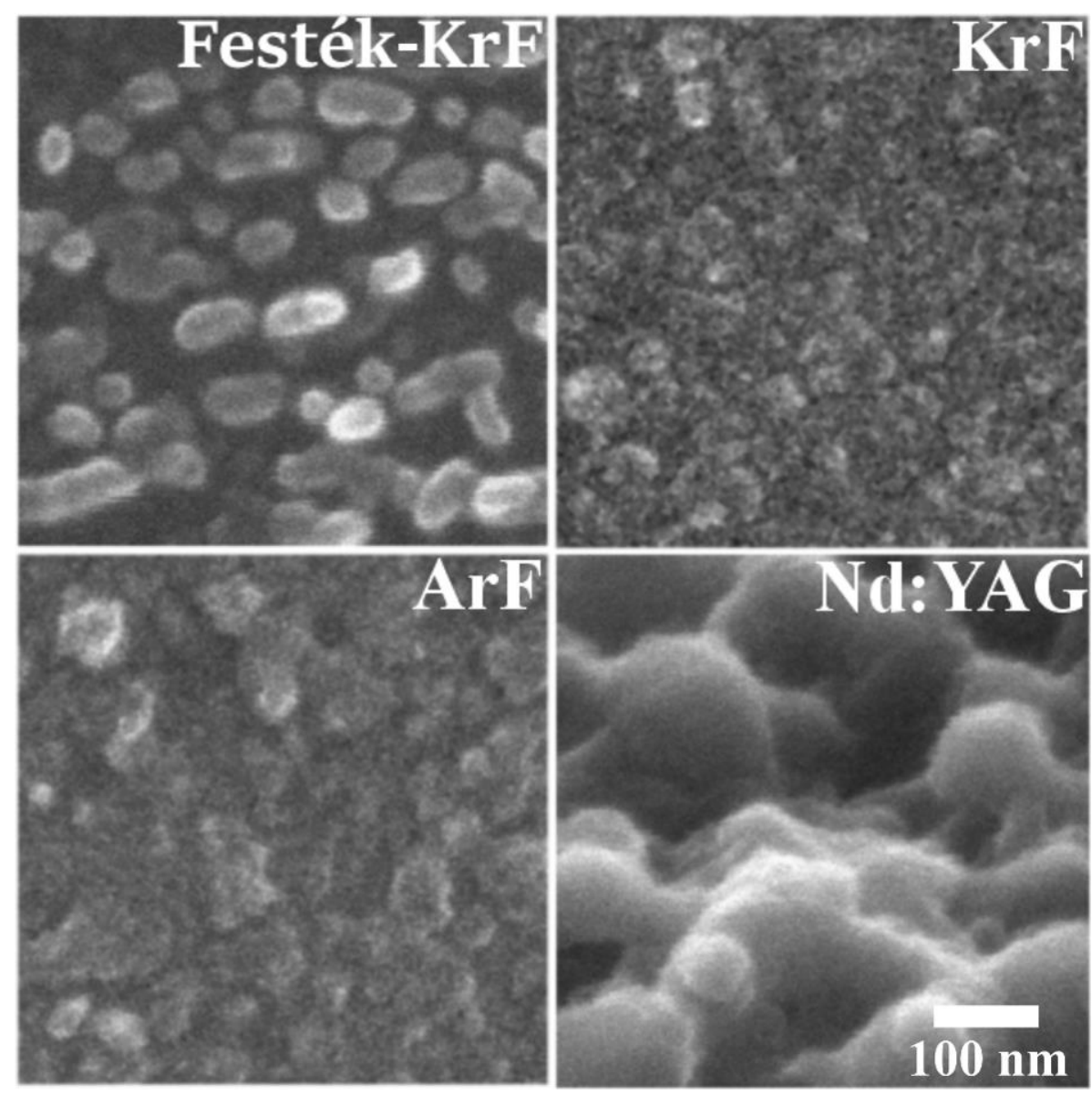

20. ábra: Nagy felbontású elektronmikroszkópos képek a 15 lézerimpulzussal megmunkált mintákról. (A különbözö minták esetén alkalmazott térfogati energiasürüségek: festék-KrF: $4,6 \times 10^{5} \mathrm{~J} / \mathrm{cm}^{3} ; \mathrm{KrF}: 3,9 \times 10^{5} \mathrm{~J} / \mathrm{cm}^{3} ; \mathrm{ArF}: 2,3 \times 10^{5} \mathrm{~J} / \mathrm{cm}^{3} ; \mathrm{Nd}: Y A G: 3,7 \times 10^{5} \mathrm{~J} / \mathrm{cm}^{3}$ ) 
Az összes lézeres kezelés eredményeként többé-kevésbé granulált felületi struktúrák megjelenését tapasztaltam, ami igazolja a Raman-spektroszkópiai mérések során kapott eredményeimet. A struktúrák mérete az excimer lézeres megmunkálás során mutatkozott a legkisebbnek, míg a Nd:YAG lézeres kezelés esetén a legnagyobbnak. Ez utóbbi lézeres kezelés esetén a képek megolvadt réteg megjelenésére engedtek következtetni. Az olvadék a visszaszilárdulás során, a felszínen kialakuló nagy nyomások miatt kifröccsent, majd abban az állapotban befagyott. A Nd:YAG és az excimer lézerek esetén látható eltérő felületi struktúra eltérő ablációs folyamatok megvalósulásáról árulkodik, ami alátámasztja az ellipszometriai eredmények során leírt feltevésemet.

\subsubsection{A fejezethez tartozó tézisem}

T2: Szub-pikoszekundumos és nanoszekundumos excimer lézerekkel, valamint nanoszekundumos Nd:YAG lézerrel üvegszerü szén mintákat felületét változtattam meg. A Raman-spektrumok kiértékelése alapján megállapítottam, hogy a felületen módosult réteg jelenik meg. A korábbi munkám során bevezetett kiértékelési eljárással meghatároztam a felületi vékonyréteg Raman-spektrumát. A Raman-spektrumok kiértékelése alapján megállapítottam, hogy a felületen a módosult rétegek kötésszerkezete a nanokristályos grafithoz hasonlít, továbbá a térfogati energiasűrüség növelésével az amorf jelleg erősödik. Spektroszkópiai ellipszometriával vizsgáltam a módosított réteg vastagságát, amely az excimer lézeres kezelések esetén a növekvő térfogati energiasürüséggel növekszik, a Nd:YAG lézeres besugárzásnál csökken. Az eltérést a különböző fotonenergia miatti eltérő gerjesztési folyamatokkal magyaráztam. Elektronmikroszkópos képek alapján olvadást csak a Nd:YAG lézeres kezelés esetén tapasztaltam, ami tisztán termális ablációra utal, szemben az excimer lézereknél várható fotoablációval. 


\section{3. Üvegszerű szén felületeken impulzuslézerekkel kialakított periodikus struktúrák vizsgálata}

Az előző fejezetben nagy energiasürüségü felületi lézerkezelés hatását vizsgáltam üvegszerü szén minták felületén. A következőkben azokat az eredményeimet ismertetem, amelyeket alacsony energiasűrűségü infravörös, valamint ultraibolya lézerimpulzusok sorozatainak alkalmazásával értem el ugyanezen az anyagon. Az alkalmazott Ti:Zafír és KrF lézerek impulzusenergiájának megtartása mellett változtattam azok impulzushosszát, ami eltérő periódusú felületi struktúrák megjelenését eredményezte. E periodikus struktúrák elektronmikroszkópos és Ramanspektroszkópiai vizsgálatainak eredményeit foglalom össze a következőkben.

\subsubsection{Ti:Zafír lézeres felületmódosítás eredményei}

A 21. ábrán mutatom be a Ti:Zafír lézerrel megmunkált üvegszerű szén felületekről készült pásztázó elektronmikroszkópos felvételeket. Ugyanazon impulzushosszhoz tartozó, de eltérő lövésszámmal megmunkált felületekről készült képek azonos sorban láthatóak. A lézerimpulzusok polarizációs irányát a 21. ábra felső részén a nyíl mutatja. Ahogy az a képeken is látszik, az első impulzusok csak enyhén módosítják a felszínt. Függetlenül az impulzushosszaktól, 100 nm-nél kisebb átmérőjü nanorészecskék jönnek létre. A nanorészecskék száma a 35 fs-os esetben a legkevesebb, míg a legtöbb a 200 ps-os megmunkálásnál jelentkezik. A felület morfológiájának változása az impulzusszám növelésével jelentős. 10 lövésnél már mindegyik impulzushossz esetén periodikus felületi struktúra jelenik meg, amely még látványosabb a 100 lövéses kezelést követően. Jelentős különbség van a struktúrák szerkezetében különböző impulzushosszak esetén. A 35 fs és 2,4 ps közötti impulzushosszakkal megmunkálva a felszínt azt tapasztaltam, hogy a struktúrák távolsága jóval kisebb, mint a lézerimpulzus központi hullámhossza, valamint kevésbé rendezettek, mint a hosszabb impulzusokkal megmunkált minták. A felületet hosszabb-rövidebb hengerszerü "nanorudak" borítják, melyek vastagsága és hossza csökken az impulzushossz növekedésével. Továbbá az impulzushossz növelésével az is észrevehető, hogy a csíkok között a kontraszt kisebb, azonban a periodicitás még fellelhető. 


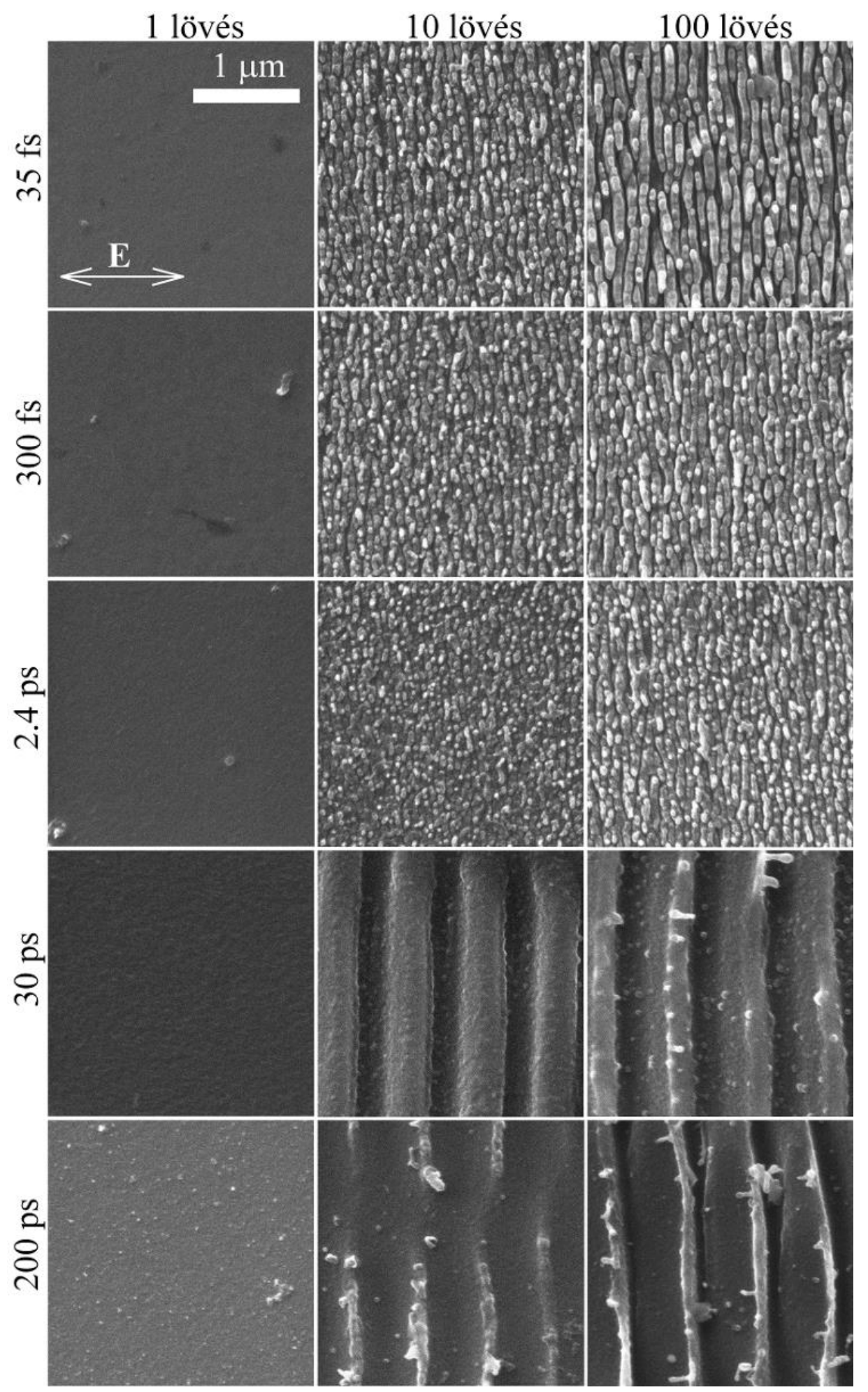

21. ábra: Pásztázó elektronmikroszkópban készült másodlagos elektronképek a különbözö számú, valamint hosszúságú Ti:Zafir lézerimpulzusokkal megmunkált üvegszerü szén felületéröl, azonos orientáció mellett. 
Az impulzushossz további növelésével drasztikus változás történik a felületen létrejövő struktúra periodicitásában és alakjában. A 30 ps-os impulzushosszakat alkalmazva a felületen sokkal szélesebb csíkok jelennek meg, melyeket nagyobb periodikus távolság jellemez. A 200 psos impulzusokkal megmunkált felületeken a struktúrák távolsága nem változik a 30 ps-os esethez képest, azonban azok szélessége kisebb és kevésbé rendezett. Továbbá, a két legnagyobb impulzushossz esetén a struktúrák felületén megfigyelhetők megszilárdult, cseppekre hasonlító részecskék is. A struktúrák irányultságára vonatkozólag azt a megállapítást tettem, hogy függetlenül az impulzusok hosszától, illetve számától, mindegyik esetben merőlegesek a lézernyaláb polarizációs irányára.

Az elektronmikroszkópos felvételeket gyors Fourier-transzformációval (FFT) további vizsgálatnak vetettem alá, hogy a periodicitás értékét meghatározzam. A képek kiértékelésének menetéről az 5.2.1. fejezetben bővebben írtam. Az FFT képek a 22. ábrán láthatóak, és az azokból meghatározott periodikus távolságokat az V. táblázatban foglaltam össze. 


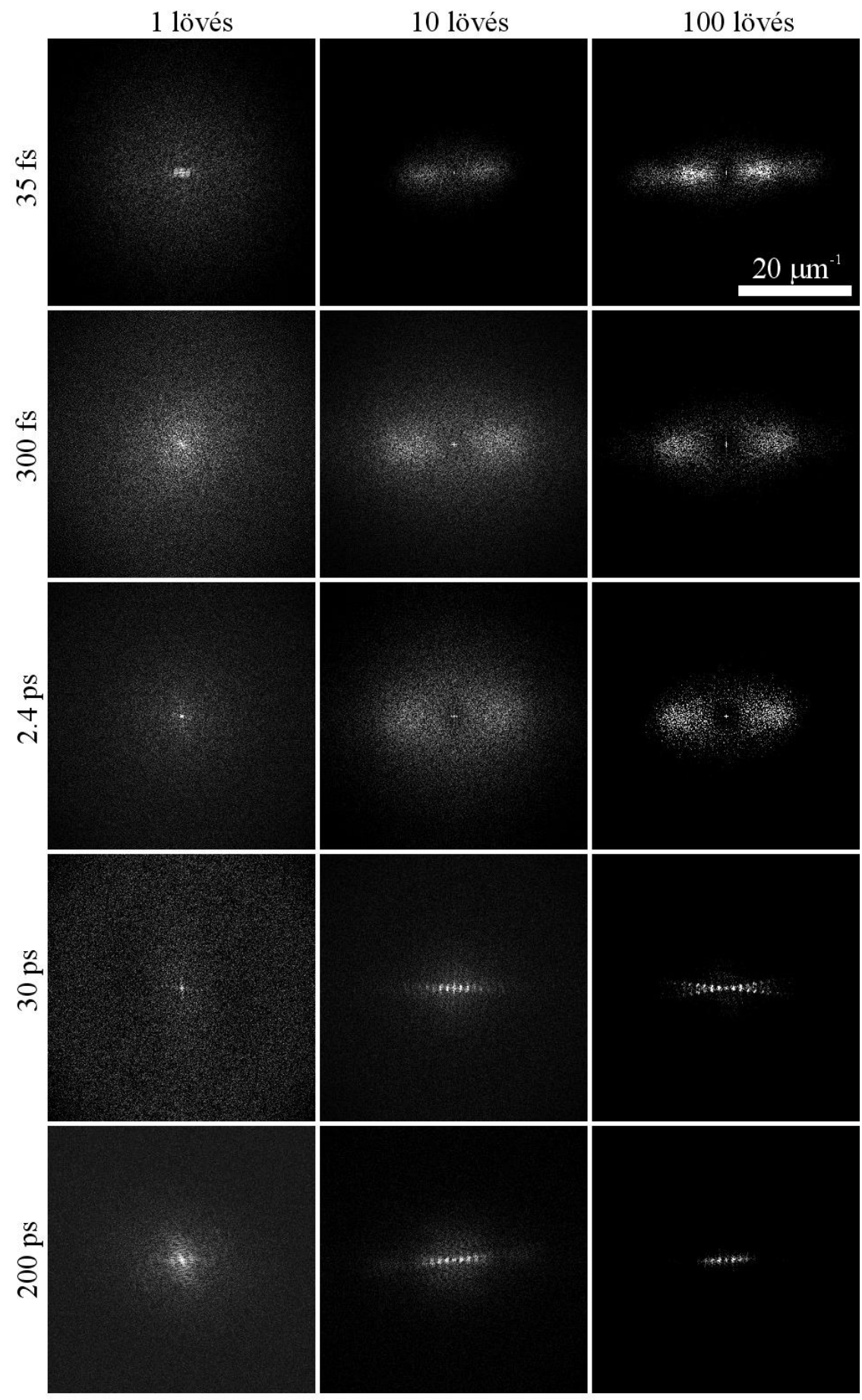

22. ábra: A Ti:Zafír lézerrel megmunkált üvegszerü szén felszínéröl készitett pásztázó elektronmikroszkópos képekhez tartozó Fourier-transzformált képek.

Az egylövéses mintákhoz tartozó FFT spektrumokon nem tapasztaltam a struktúrák periodicitását mutató csomópontok megjelenését. Nagyobb lövésszámmal megmunkált minták 
esetén azonban már észrevehető csomópontok a képeken. A 35 fs és 2,4 ps közötti impulzushosszakhoz tartozó FFT képeken nagyobb területen elterülő foltok megjelenését figyeltem meg, amelyek szintén azt mutatják, hogy ezekben az esetekben a struktúrák kevésbé rendezettek.

\begin{tabular}{ccc}
\hline & $\begin{array}{c}\text { Periodikus struktúrák távolsága }[\boldsymbol{\mu m}] \\
\text { 10 lövés }\end{array}$ & $\mathbf{1 0 0 ~ l o ̈ v e ́ s ~}$ \\
\hline $35 \mathrm{fs}$ & 0,203 & 0,164 \\
$300 \mathrm{fs}$ & 0,138 & 0,122 \\
$2,4 \mathrm{ps}$ & 0,139 & 0,135 \\
$30 \mathrm{ps}$ & 0,850 & 0,766 \\
$200 \mathrm{ps}$ & 0,776 & 0,781 \\
\hline
\end{tabular}

V. táblázat: A Ti:Zafír lézerrel kezelt mintákon jelentkezö periodikus struktúrák, FFT analízissel meghatározott távolsága a különbözö impulzushosszak esetén.

A hosszabb impulzushosszakhoz (30 ps, 200 ps) tartozó FFT képeken jól elkülönülö, éles maximumok fedezhetőek fel, továbbá azok felharmonikusai is észrevehetők. Ezek jól mutatják, hogy ezekben az esetekben sokkal szabályosabb struktúrák jönnek létre. A 30 ps-os impulzushosszal megmunkált minta esetén a periodikus struktúra minőségét az is jól jellemzi, hogy fehérfénnyel megvilágítva, azt spektrális komponenseire bontja, tehát optikai rácsként müködik. Ezt igazoldandó, egy hagyományos, fényforrásból, fókuszáló lencséből, résből, kollimáló lencséből, diszperzív elemből, valamint egy ernyőből álló spektrográfot építettem, ahol a rács helyére a 30 ps-os impulzussorozattal megvilágított mintát tettem. A belépő rést egy halogén izzólámpa fényével világítottam ki. Az elrendezésről készült kép a 23. ábra a) részén, a spektrálisan bontott fehérfény pedig a b) részén látható. 


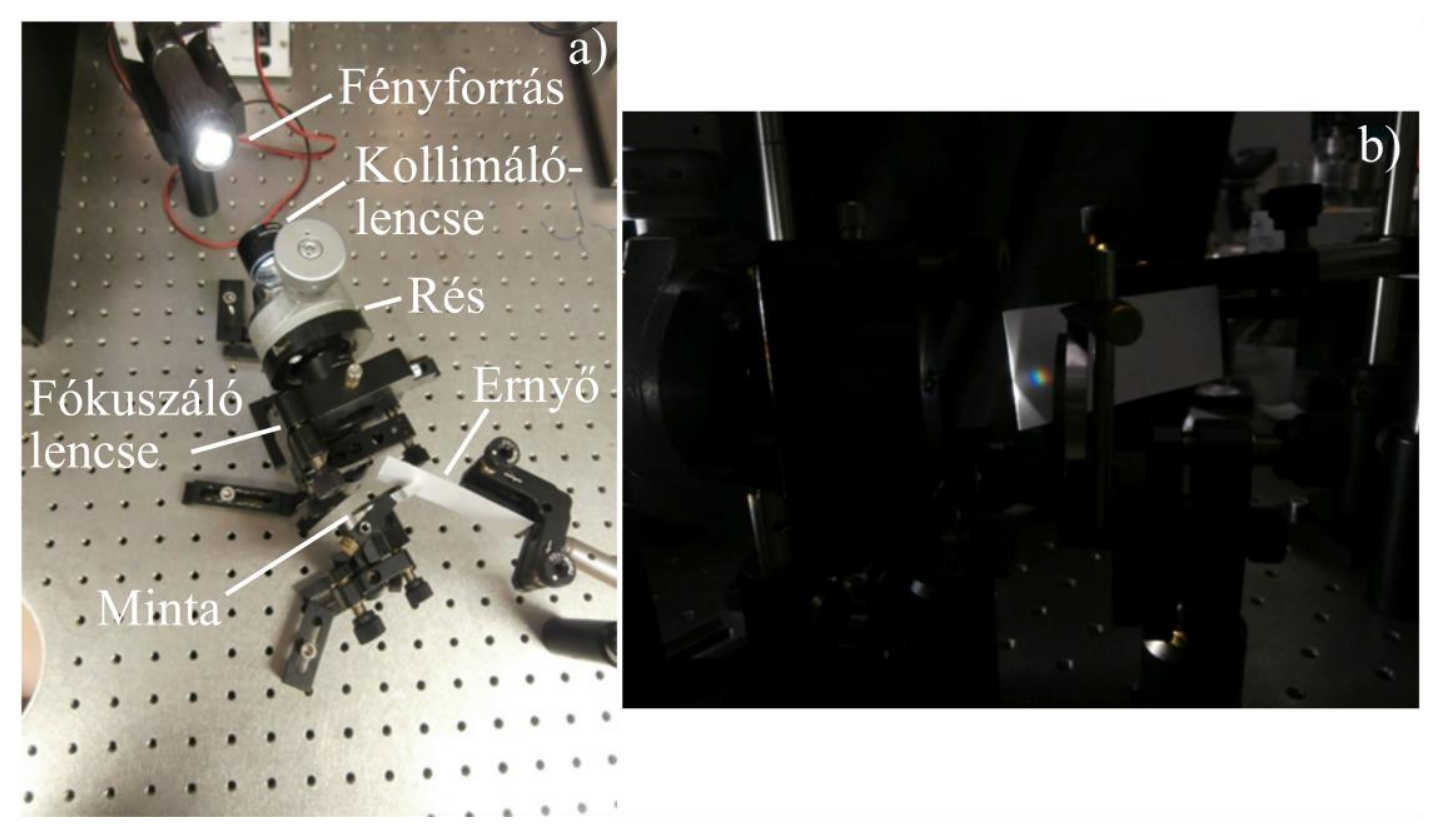

23. ábra: a) a 30 ps-os impulzussorozattal megvilágitott minta nagyfokú periodicitásának igazolására felépitett spektrográf és b) a spektrálisan bontott fehérfény.

Az FFT képek alapján számolt periodikus struktúratávolság a 35, illetve a 300 fs és a 2,4 psos lézeres kezelés esetén 165 és $120 \mathrm{~nm}$ között változik, amit az irodalomban HSFL-nek (High Spatial Frequency Laser Induced Periodic Structure) neveznek. A hosszabb, 30 és 200 ps-os lézerimpulzusokkal megvilágított mintákon már a megmunkáló fény hullámhosszával összemérhető struktúratávolság jön létre, számszerủen 780 és $800 \mathrm{~nm}$. Ezekre a megmunkáló impulzus hullámhosszával összemérhető struktúratávolságokra az irodalomban LSFL-ként (Low Spatial Frequency Laser Induced Periodic Structure) hivatkoznak.

A periodikus struktúrák kialakulásának hátterében meghúzódó folyamatok mélyebb megértése céljából a Ti:Zafír lézer 200 ps-os impulzusaival megvilágított mintáról témavezetőm segítségével egy átnézeti SEM képet készítettem, mely a 24. ábrán látható. Az ábrán jelöltem azokat a területeket, ahol nagyított képek készültek. A megmunkált területen kívüli részt (nincs nagyított kép), az egy impulzussal megmunkált foltokhoz hasonlóan, nanoméretü szemcsék borítják, ami nem más, mint a megmunkálás következtében kiszóródott törmelék. A megmunkált területről felvett nagy felbontású képek jól mutatják, hogy a különböző területek eltérő struktúrákkal jellemezhetők. A folt szélén felfedezhetők a rövidebb impulzushosszaknál tapasztalt vékonyabb csíkok (29. a) nagyított kép). A folt közepe felé haladva ezek a struktúrák egyre kisebb 
számban jelentkeznek. Az ábra a) és b) részein jól látható, hogy a struktúrák nem csak a felületen formálódtak, hanem az anyag mélyebb részében is, a vékony csíkok egymás tetején helyezkednek el. A folt közepén (c) rész) a mélységbeli struktúrával rendelkező vékonyabb csíkok már nem fedezhetőek fel a felszínen, és a nagyobb periódusú struktúra láthatóvá válik. A struktúrákat jellemzőkarakterisztikus távolság a folt széléről a közepe felé haladva 200 nm-ről 610 nm-re nőtt meg.

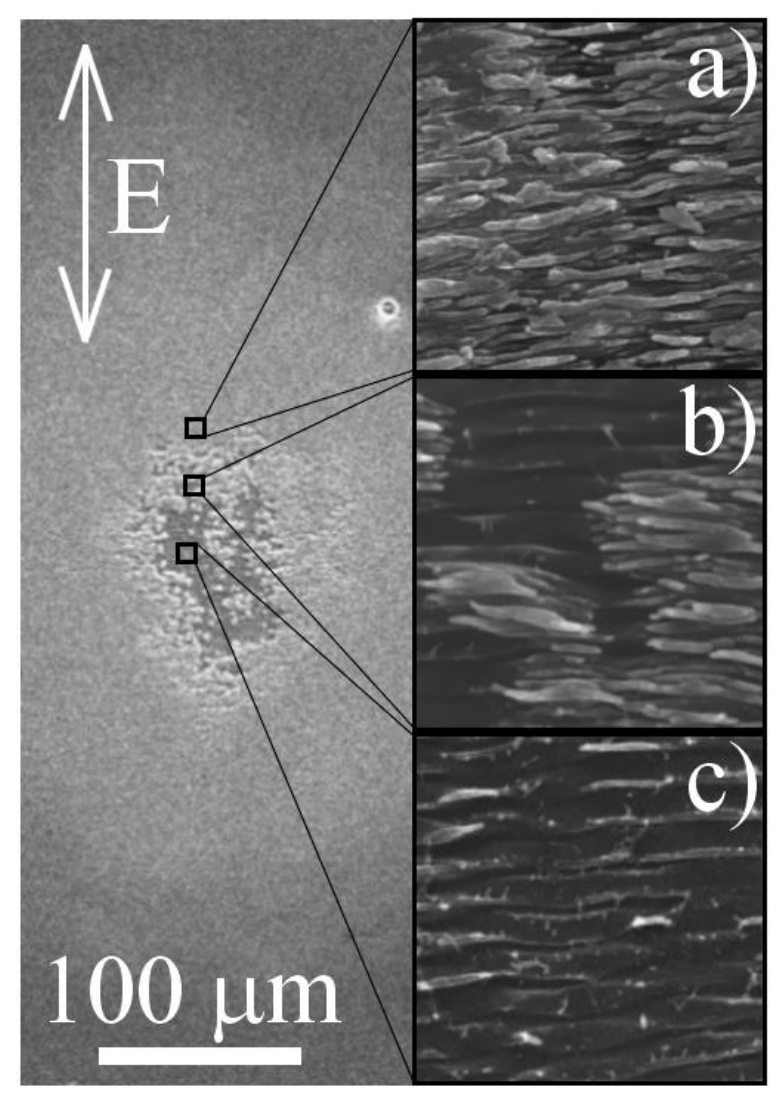

24. ábra: 200 ps-os impulzushosszal megmunkált minta átnézeti SEM képe.

Mivel a céltárgyat megmunkáló impulzusok térbeli intenzitáseloszlása közel Gaussos volt, így a fentebb bemutatott ábrából azt a következtetést szürtem le, hogy struktúrák kialakulásának hátterében fontos szerepet játszik a lokális energiasürüség is. 


\subsubsection{Festék-KrF lézeres felületmódosítás eredményei}

A 25. ábrán láthatóak a festék-KrF lézerrel megmunkált üvegszerü szén mintákról készült elektronmikroszkópos képek.

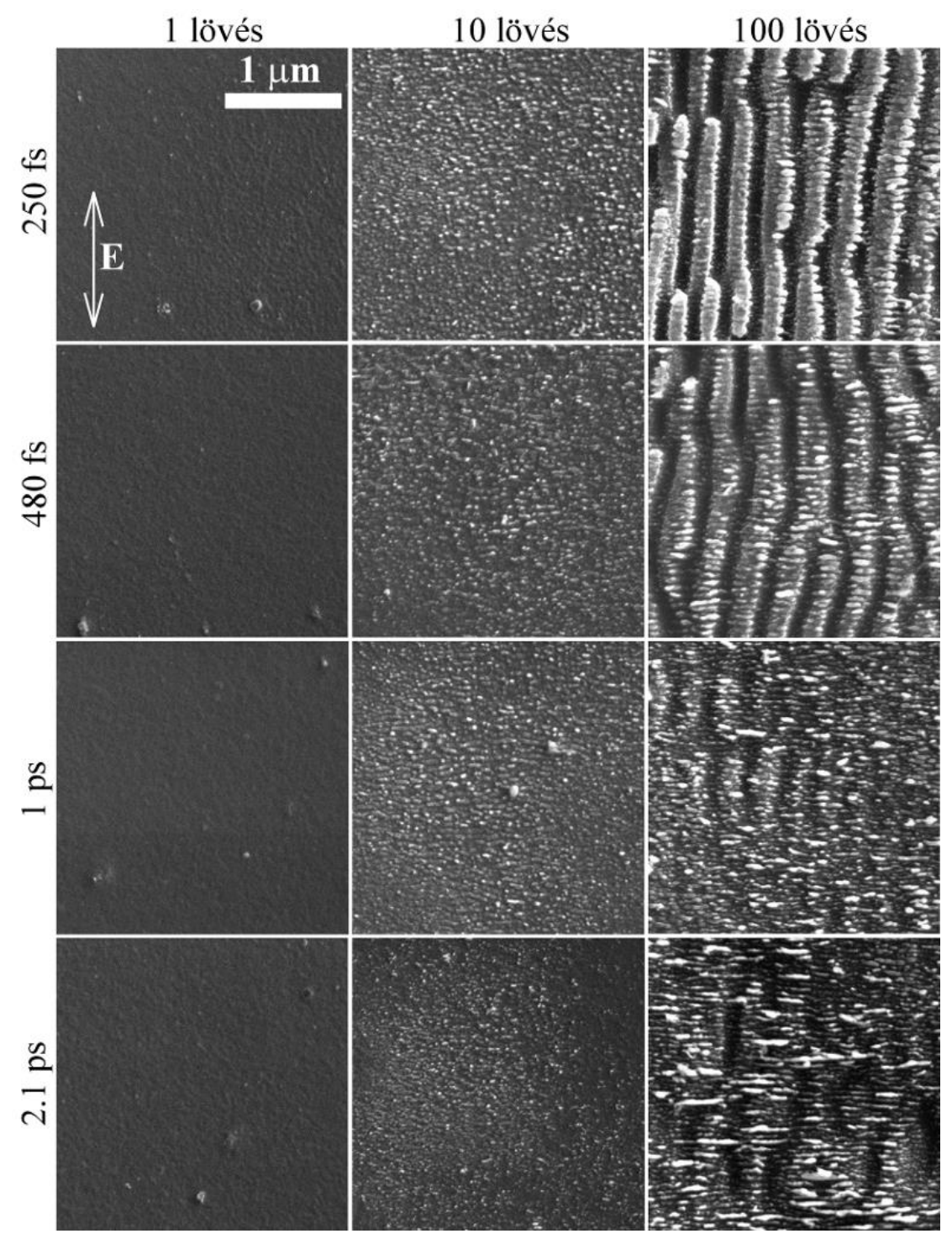

25. ábra: Elektronmikroszkópos felvételek a festék-KrF lézerrel megmunkált üvegszerü szén minták felszinéröl.

Ahogy a Ti:Zafír lézeres kezelésnél látszódott, ebben az esetben is az egy lövéses megmunkálás $100 \mathrm{~nm}$ alatti szemcsék megjelenését eredményezi a felszínen. A lövésszám növelésével a szemcsék egyre kontrasztosabbak lesznek, számuk növekszik. A másodlagos 
elektronképeken a kontrasztot a felületi gradiens adja. A szemcsék kontrasztjának növekedése ezért durvább felület megjelenésére utal. 10 lézerimpulzus esetén a szemcsék csíkokba rendezőnek, amelyeknek a távolsága $50 \mathrm{~nm}$ körüli, és irányultsága merőleges a lézerimpulzus polarizációs irányára. A 100 lövéssel megmunkált minták esetén a kisebb struktúrák továbbra is megmaradnak a felszínen, azonban nagyobb periódusú struktúrák is megjelennek, melyek már párhuzamosak a polarizációs iránnyal. A nagyobb periódussal rendelkező struktúrák távolsága nagyjából 300 nm, ami a lézer hullámhosszával összemérhető nagyságú. Ezek a struktúrák valamennyi impulzushossz esetén felfedezhetőek a felszínen, azonban ahogy az az elektronmikroszkópos képeken jól látható, az impulzushossz növelésével a kontrasztjuk csökken. Sajnos a kísérleti körülmények nem tették lehetővé, hogy tovább növeljem az impulzushosszat néhány pikoszekundumnál, ami egy küszöbértékként jelentkezett a Ti:Zafír lézerrel végzett kísérletek esetén.

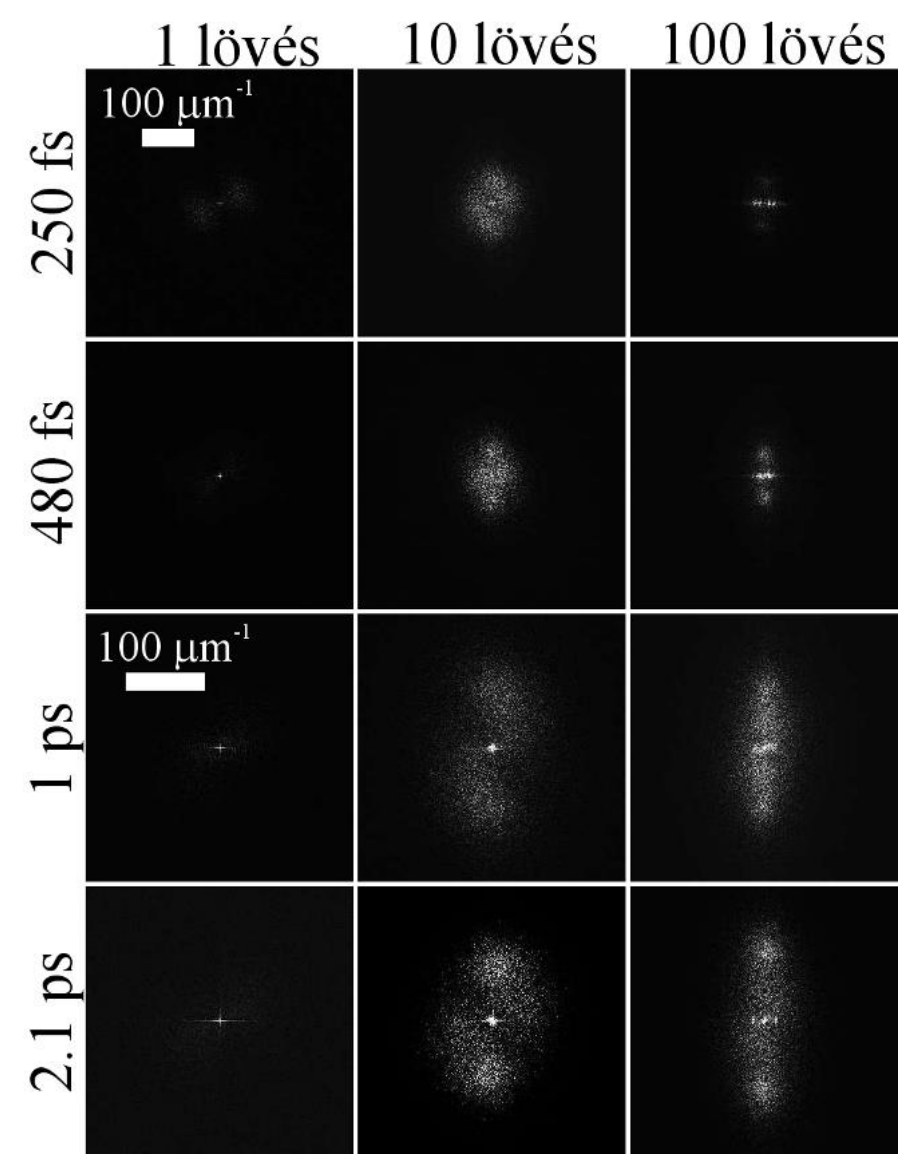

26. ábra: FFT képek a festék-KrF lézerrel megmunkált üvegszerü szén minták elektronmikroszkópos képeiröl. A 250 fs és a 480 fs-os esetekhez tartozó skála a bal felsö képen található, míg az 1 ps és a 2,1 ps-os esetekhez tartozó az 1 lövéses, 1 ps-os impulzushosszhoz tartozó képen. 
Az elektronmikroszkópos felvételek Fourier-transzformált képei a 26. ábrán láthatók. Ahogy azt a Ti:Zafír lézerrel megmunkált minták esetén is tapasztaltam, itt sem jelennek meg periodikus struktúrákra utaló maximumok az egy lövéses minták FFT képein. A 10 lövéses minták esetén a Fourier-analízis igazolta a SEM képek vizsgálata során látottakat, miszerint a felületen megjelenő nanorészecskék periodikus struktúrákba rendeződnek. Ennek jele az FFT képek középpontja alatt és felett megjelenő elkent maximum, melyek kontrasztja alapján elmondható, hogy a struktúrák nem olyan markánsak, mint a Ti:Zafír lézeres kezelésnél tapasztaltak. Az elhelyezkedésük megmutatta, hogy a struktúrák irányultsága merőleges a polarizációs irányra. A maximumok alapján meghatároztam a struktúrák karakterisztikus távolságát, mely nagyjából 80 nm-nek adódott. Ezen struktúrák periodicitása és az impulzushossz között nem mutatkozott összefüggés ezen az impulzushossz tartományon. A 100 lövéssel megmunkált minták esetén az FFT képek továbbra is mutatják az elkent maximumot, azonban a középponthoz közelebb, a korábbiakra merőlegesen megjelenik egy sokkal élesebb maximum, ami jelzi a nagyobb periódussal rendelkező struktúrák létrejöttét. Ezek párhuzamos orientációt mutatnak a lézer polarizációs irányával, periodikus távolságuk pedig a lézer hullámhosszánál valamivel nagyobb. A különböző impulzushosszal és lövésszámmal megmunkált minták esetén az FFT képekből meghatározott periodikus struktúratávolságokat a VI. táblázat tartalmazza.

\begin{tabular}{cccc}
\hline \hline & & $\begin{array}{c}\text { Periodikus struktúrák távolsága }[\boldsymbol{\mu m}] \\
\mathbf{1 0} \text { lövés }\end{array}$ & $\mathbf{1 0 0}$ lövés \\
\hline \multirow{2}{*}{$\mathbf{2 5 0}$ fs } & párhuzamos & - & 0,319 \\
& merőleges & 0,094 & 0,084 \\
\multirow{2}{*}{$\mathbf{4 8 0}$ fs } & párhuzamos & - & 0,288 \\
& merőleges & 0,061 & 0,070 \\
\multirow{2}{*}{$\mathbf{1}$ ps } & párhuzamos & - & 0,430 \\
& merőleges & 0,060 & - \\
\multirow{2}{*}{$\mathbf{1} \mathbf{~ p s}$} & párhuzamos & - & 0,271 \\
& merőleges & 0,066 & 0,043 \\
\hline \hline
\end{tabular}

VI. táblázat: A festék-KrF lézerrel kezelt minták esetén, a polarizációs iránnyal párhuzamos illetve arra meröleges periodikus struktúra távolságok. 


\subsubsection{Kötésszerkezet vizsgálata Raman-spektroszkópiával}

A 27. ábra a) részén a Ti:Zafír, b) részén pedig a festék-KrF lézerrel megmunkált mintákon mért Raman-spektrum láthatóak. Méréseim közül a 100 lövéssel megmunkált mintákról felvett spektrumokat mutatom be.
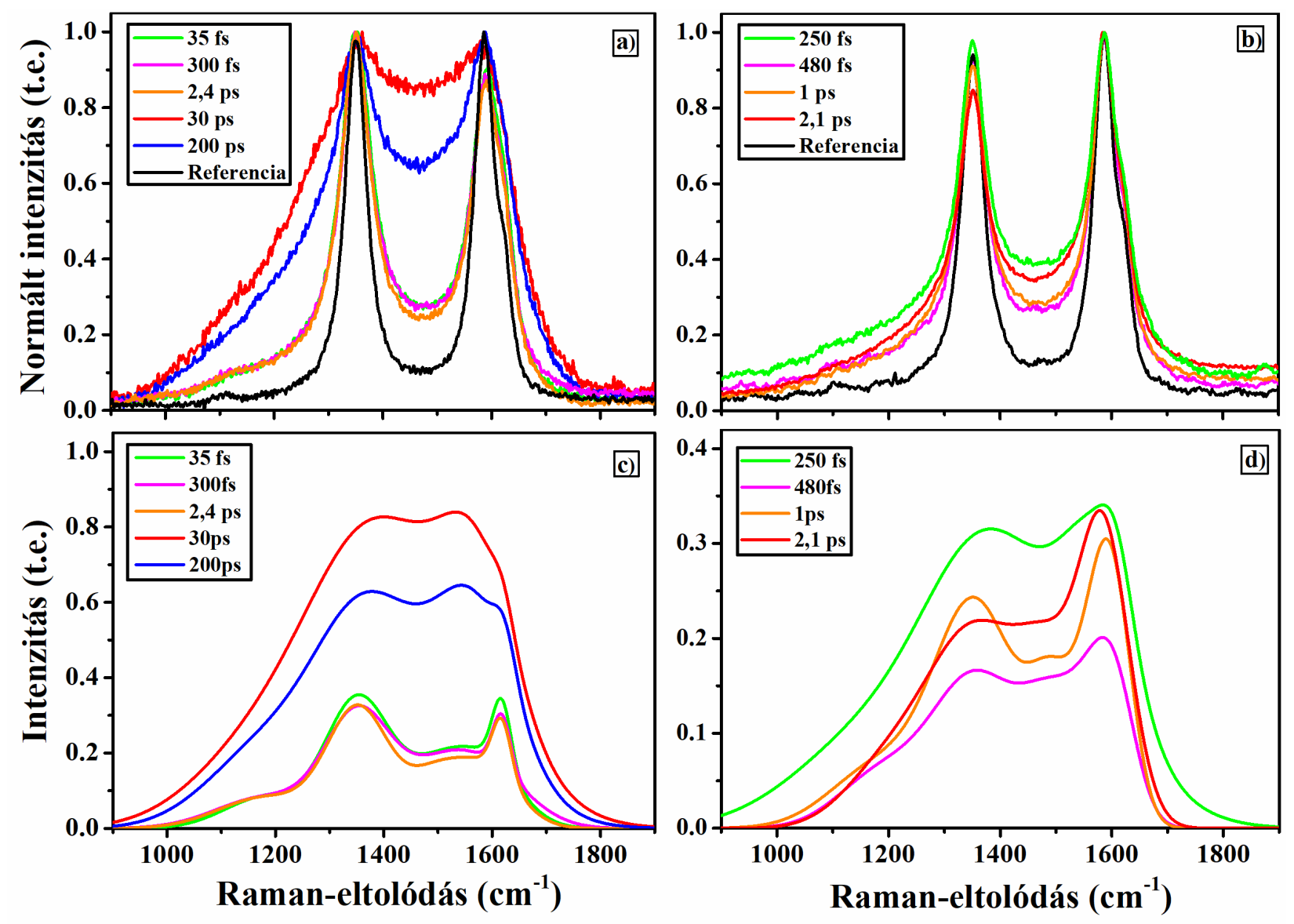

27. ábra: a) a Ti:Zafir lézerrel megmunkált területen mért és c) az illesztési eljárással kapott réteg Raman-spektruma. b) a festék-KrF lézerrel megmunkált felületeken mért, valamint d) a rétegre vonatkozó Raman-spektrumok.

A festék-KrF lézerrel kezelt minták esetén a Raman-spektrumok kismértékủ változást mutatnak a referencia spektrumhoz képest (27. b) ábra). A D és G csúcsok az impulzushossz növelésével egyre jobban kiszélesednek, de a leghosszabb impulzussal megmunkált minta esetén is nagyban hasonlítanak az üvegszerủ szén spektrumához. A Ti:Zafír lézer esetén a 35 és 300 fs valamint a 2,4 ps-os impulzushosszakkal kezelt foltokról származó Raman-spektrumok szintén 
hasonló jelleget mutatnak a megmunkálatlan területről származó referencia spektrumhoz képest (27. a) ábra). Nagyobb impulzushosszak esetén viszont markáns változást figyeltem meg. A spektrumok alapján elmondható, hogy a különbözö lézerekkel kezelt üvegszerü szén felületén egy vékonyréteg alakul ki. Továbbá ennek a rétegnek a vastagsága kevesebb, mint a Ramanspektroszkópiai méréseimhez használt gerjesztő lézer behatolási mélysége. E miatt a detektált jel a felületi vékonyrétegből és az alatta elhelyezkedő hordozóból is származik. Így a mért spektrumok kiértékelésénél a korábbi munkám során bevezetett illesztési eljárásból indultam ki.

Az eltérő impulzusenergiák, valamint impulzushosszak miatt az illesztési eljárást módosítanom kellett. A referencia spektrumot továbbra is 3 görbével illesztettem meg, amelyek leírták a hordozóhoz tartozó $D, G$, és a $G$ csúcs mellékcsúcsaként jelentkező D’ csúcsokat. A mintákon történt mérések kiértékelése során ezeknek a csúcsoknak a paramétereit ebben az esetben is rögzítettem, és beszoroztam a már ismert súlyfaktorral. A módosított réteg Raman-jelének leírásához Gauss-függvényeket használtam, melyeknek a számát ezeknél a mintáknál 5-re emeltem, mivel ekkor értem el a legjobb illesztéseket. Nagyobb számú függvény bevezetése már nem javította az illesztés minőségét, így nem tartottam indokoltnak. A csúcsok központi hullámszáma alapján jó egyezést mutattak az irodalomban használt D $\left(1360 \mathrm{~cm}^{-1}\right), \mathrm{G}\left(1580 \mathrm{~cm}^{-1}\right)$, D2 $\left(1620 \mathrm{~cm}^{-1}\right)$, D3 $\left(15000 \mathrm{~cm}^{-1}\right)$ és D4 $\left(1180 \mathrm{~cm}^{-1}\right)$ csúcsok pozícióival [101]. Az illesztést ebben az esetben is az Origin nevü program segítségével végeztem. Az illesztés során a változók nagy száma miatt az alábbi eljárást alkalmaztam: a súlyfaktor értékét fixen tartva, a program segítéségével megillesztettem a Gauss-függvényeket, majd kiszámoltattam az illesztés jóságát jellemző $\chi^{2}$ értéket. Ezt a folyamatot többször elvégeztem a súlyfaktor szisztematikus, 0 és 1 közötti változtatása mellett. Az illesztésekböl kapott $\chi^{2}$ értékeket a súlyfaktor értékének függvényében ábrázolva egy jól definiált minimummal rendelkező görbét kaptam, ahogy az a 28. ábrán is látható. Erre a görbére egy polinom függvényt illesztettem, aminek meghatározva a minimumát megkapható az a súlyfaktor érték, ahol a legjobb illeszkedés érhető el. Ennél a súlyfaktor értéknél egy újabb illesztést végeztem, megkapva így a réteget jellemző csúcsok végleges paramétereit. 


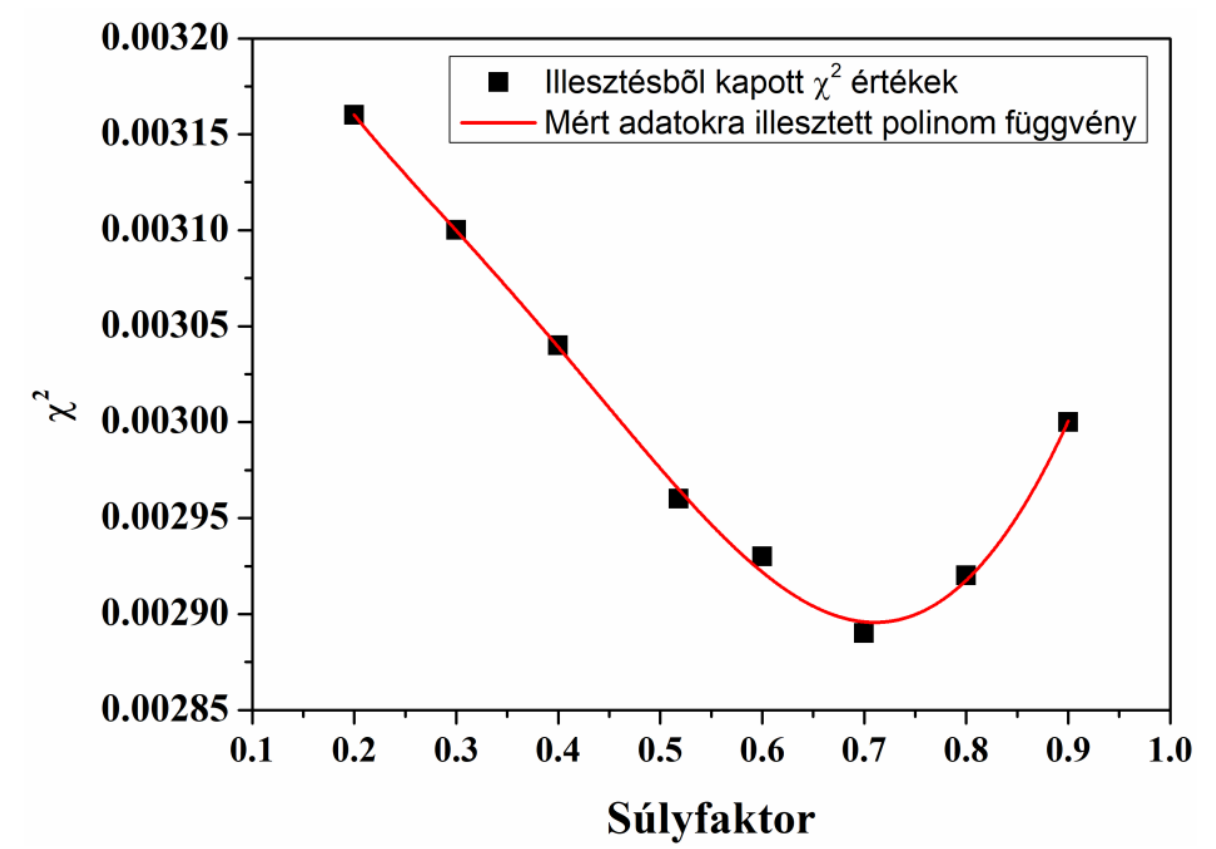

28. ábra: A 35fs-os Ti:Zafí lézer impulzusokkal megmunkált mintán mért Raman-spektrumok illesztése során kapott $\chi^{2}$ értékek és az illesztett polinom-függvény a súlyfaktor függvényében.

A Ti:Zafír lézerrel módosított rétegre vonatkozó Raman-spektrumok a 27. ábra c) részén láthatók. A mérések alapján elmondható, hogy az üvegszerủ szénre jellemző D és G csúcsok a megmunkálást követően enyhén kiszélesednek. Másrészt a módosított réteg Raman-spektrumai alapján el lehet különíteni két csoportot, ahogy az elektronmikroszkópos képek esetén is meg lehetett ezt tenni a struktúrák periodicitása alapján. Az első csoportot a rövid impulzusokkal kezelt minták alkotják. Ezek esetén a rétegre jellemzö Raman-spektrumok közel együtt futnak, a D és G sávok kiszélesedése ezekben az esetekben a legkisebb. A két leghosszabb, tehát a 30, illetve a 200 ps-os esetekben szélesedik ki a D és a G csúcs a legjobban. Ezt az elkülönülést megfigyelhetjük, ha a súlyfaktor értékeit az impulzushossz függvényében ábrázoljuk (29. ábra) Látható, hogy a kisebb (35fs - 2,4 ps) impulzushosszak esetén a súlyfaktor nagyobb értéket vesz fel, tehát vékonyabb réteg jelenik meg a felszínen. Nagyobb impulzushosszak esetén (30 ps 200 ps) a súlyfaktor vastagabb réteg jelenlétéről árulkodik.

A 27. ábra d) részén látható a festék-KrF lézerrel megmunkált minták esetén a réteg Ramanspektrumára kapott eredmények. Ebben az esetben is a D és a G csúcsok jelentős kiszélesedését tapasztaltam, azonban ezen az impulzushossz-tartományon nem látható jelentős változás. A súlyfaktorra kapott értékek szintén a 29. ábrán láthatók, melyek közel azonos értéket vesznek fel a 
hasonló impulzushosszú Ti:Zafír lézerrel megmunkált mintáknál tapasztaltakkal. A súlyfaktor értéke alapján elmondható, hogy ebben az esetben is a néhány pikoszekundumig terjedő impulzushosszak vékony módosított réteg megjelenését eredményezik a felszínen.

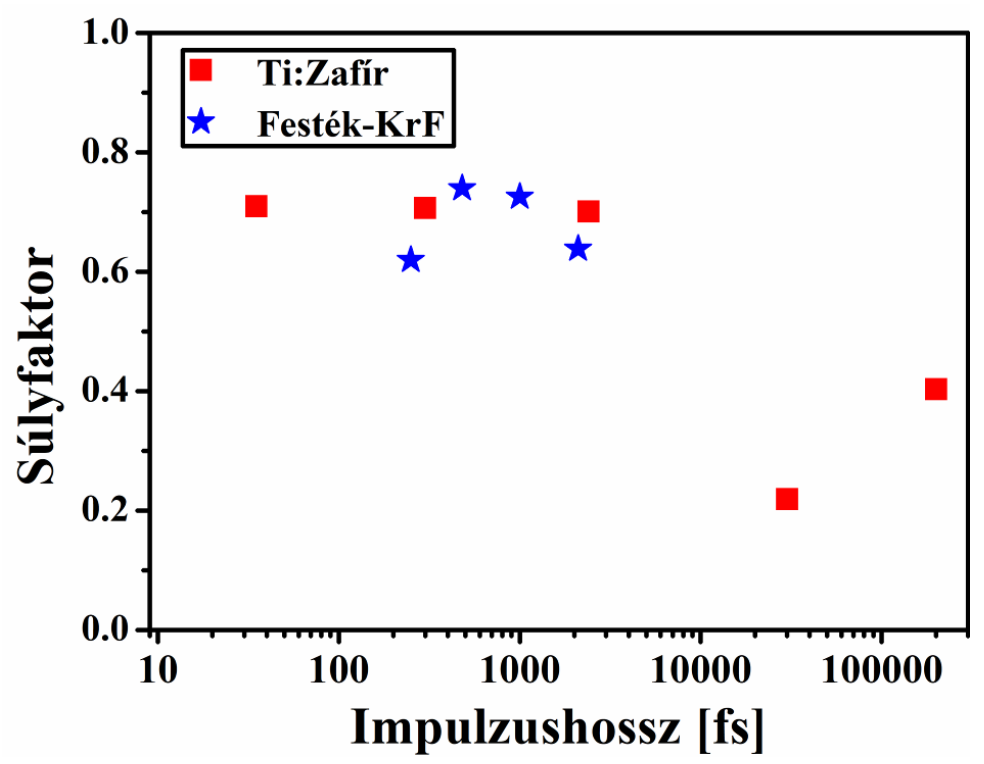

29. ábra: Az illesztésekből kapott, a hordozóból származó Raman jel intenzitását jellemző súlyfaktor értékek az impulzushossz függvényében.

\section{Diszkusszió, következtetések:}

Üvegszerü szén felszínén infravörös Ti:Zafír, valamint ultraibolya festék-KrF lézerekkel végzett kísérleteim során azt tapasztaltam, hogy az impulzushossztól függetlenül, az első lövés hatására nem alakul ki a felületen periodikus struktúra, csupán 100 nanométer alatti szemcsék jelennek meg, ami nem más, mint a megmunkálás után visszahulló törmelék. 10, illetve annál nagyobb számú impulzussal megmunkált minták esetén már megjelennek a felszínen periodikus struktúrák: infravörös lézer használata esetén HSFL struktúrák alakulnak ki rövid impulzushosszak esetén, illetve hosszabb impulzus hosszak esetén, ha a lokális lézerintenzitás csökken. Kísérleteim alapján a polarizációra merőleges LSFL kialakulásához a nagyobb impulzushosszak és lokális intenzitások szükségesek. Ez az a két feltétel, amely ahhoz szükséges, hogy a felületen olvadás történjen. Az impulzushossz növelésével ugyanis a termalizáció folyamata az impulzus beérkezése során végbemegy, így adott intenzitás felett megjelenik a klasszikus olvadási folyamat. A 
periodikus struktúra kialakulásának magyarázatához még egy jelenséget figyelembe kell vennünk. Az egy impulzussal megmunkált felszínen tapasztaltak alapján az elsőt követő további impulzusok a felszínen létrehozott szemcsékkel kölcsönhatva módosítják a felszínt. Ezeken a struktúrákon a beérkező impulzus szóródása valósul meg, amely a beérkező impulzussal konstruktívan interferál és így periodikus intenzitás-moduláció jön létre [28]. Ez az intenzitás-moduláció a felületen periodikus energia abszorpciót hoz létre, amely ennek megfelelő periodikus hőmérsékleteloszlást, és kapilláris hullámok megjelenését eredményezi a hordozó felületén az interferencia által meghatározott megolvadt vékony réteg csíkokban. A megszilárdulást követően ezek a felületi hullámok befagyhatnak és így eredményezhetik a kísérleteim során tapasztalt LSFL megjelenését. Abban az esetben, ha az energiasürüség nem elegendő ahhoz, hogy a hőmérséklet meghaladja az olvadáspontot, akkor LSFL struktúrák nem alakulhatnak ki, még a termalizációs időt meghaladó impulzushosszak esetében sem.

A kísérleti eredményeim alapján a termalizációs határ 2,4- és 30 ps között lehet, ugyanis ez az intervallum, ahol a kétféle periodicitású struktúra közötti átmenet megvalósul. Ez az adat egyezést mutat az irodalmi eredményekkel [102-104]. Ezt a megfigyelést továbbá alátámasztják a Raman-spektroszkópiai mérések, amelyek kiértékelésekor adódó súlyfaktor jelentősen kisebb értékünek adódott 30 ps-os impulzusidők felett, utalva a céltárgy felszínén megnövekedett amorfizált rétegvastagságra. Az amorf réteg az olvadt területek visszaszilárdulásakor jöhetett létre. Továbbá 2,4 ps-nál hosszabb impulzussal történt megmunkálások esetén az LSFL megjelenése mellett olvadás nyomát láttam a nagyfelbontású másodlagos elektronképeken is.

Ha a lézerimpulzus-anyag kölcsönhatási idő rövidebb a termalizációs időnél, akkor a szórt elektromágneses hullám az anyag töltéshordozó rendszerével hat kölcsön, amely során plazmonikai effektusok léphetnek fel [19, 29-31, 105]. Számos olyan kutatás fellelhető az irodalomban, melyekre a 3.1.2. fejezetben ki is térek, ahol kristálytanilag jól orientált mintákon figyeltek meg a megmunkáló lézer hullámhosszánál jóval kisebb periodikus távolságú struktúrákat. Az én kutatásaim üvegszerủ szén mintákon történtek, mely kristálytanilag nem egy jól orientált anyag [106], mégis a lézeres besugárzás hatására az említett HSFL ugyanúgy megjelenik a felszínen. Ez a megfigyelésem arra enged következtetni, hogy az ilyen típusú struktúrák létrejötte független a kötésszerkezettől valamint a kristálytani rendezettség fokától. 


\subsubsection{A fejezethez tartozó tézisem}

T3: Ultrarövid, femtoszekundumos fényimpulzusokat kibocsátó infravörös Ti:Zafír, valamint az ultraibolya festék-KrF lézerek segítségével üvegszerü szén felszínén periodikus struktúrákat hoztam létre. Az infravörös impulzusokkal megmunkált minták esetében az impulzushossz változtatásával el tudtam érni a hullámhosszal összemérhető, valamint annál 5-ször kisebb periódusú struktúrák kialakulását, amelyek a lézerfény polarizációs irányára merőlegesek voltak. Kísérleteim alapján a nagyobb struktúrák kialakulásához nagyobb impulzushosszak és nagyobb lokális intenzitások szükségesek. Raman-spektroszkópiai mérésekkel megmutattam, hogy a felszínen egy módosított vékonyréteg jön létre, melynek vastagsága a nagyobb periodikus távolsággal rendelkező struktúrák esetén nagyobb. Ezek alapján megállapítottam, hogy a nagyobb struktúrák megjelenéséhez olvadás szükséges. Ekkor kapilláris hullámok jelenhetnek meg a bejövő és szórt lézerfény interferenciájának következtében. Ultraibolya impulzusokkal megmunkált minták esetén ugyancsak tapasztaltam hullámhossz nagyságú és annál 3,5-szer kisebb periódusú struktúrák megjelenését, azonban az előbbiek orientációja ebben az esetben a lézerfény polarizációs irányával párhuzamosnak bizonyult. 


\subsection{Pumpa-próba null-ellipszométer tervezése, megépítése és kalibrációja ultragyors folyamatok vizsgálatára}

A felületek ultragyors lézeres gerjesztési folyamatai hatására létrejövő változások ex-situ vizsgálataival foglalkoztam a korábbi fejezetekben. A lézerimpulzusok hossza azáltal szabja meg a lézeres abláció jelenségeit, hogy a gerjesztés időtartamában, és közvetlenül azt követően milyen karakterisztikus folyamatok játszódnak le. Erre jó példát mutattak az előző alfejezetben végzett kísérleteim: látványos különbséget mutatott az ultrarövid és rövid lézerimpulzusok hatásai között az olvadási folyamat hiánya, illetve megjelenése. Ezen folyamatok időbeli vizsgálatára alkalmasabbak az in-situ vizsgálatok. A gerjesztés időtartama alatti, illetve az azt követő időtartományban a non-invazív ultragyors optikai eljárások használhatók. A szegedi ellipszométeres csoportban már régebben megfogalmazódott az igény egy szubpikoszekundumos időbeli feloldású ellipszométer építésére. A doktori munkám során egy ilyen ellipszométert terveztem és valósítottam meg, amiről az alábbiakban számolok be.

\subsubsection{Mérőberendezés felépítése}

Az anyagok optikai adatainak tranziens jellegü változása fontos információt hordoz a lézeres anyagmegmunkálás során bekövetkező folyamatok mélyebb megértéséhez. Az ellipszometriai mérésekkel az anyagok optikai adatai egyszerüen meghatározhatók, azonban a kereskedelemben elérhető ellipszométerek nem alkalmasak gyors, piko- vagy femtoszekundumos skálán lejátszódó folyamatok vizsgálatára. A következő kutatási munkám során célom az volt, hogy megtervezzek, és méréseket végezzek egy olyan eszközzel, amely alkalmas a rövid lézerimpulzusok szilárdtestek felszínén okozta tranziens optikai változások vizsgálatára.

A kísérleteimhez megterveztem egy pumpa-próba elrendezésben müködő nullellipszométert, amelynek sematikus ábrája, és a megvalósított eszközről készült fénykép a 30. ábrán látható. A berendezés megtervezése során szem előtt tartottam, hogy egy olyan eszközt valósítsak meg, amely precíz, pontos mérést tesz lehetővé, és segítségével a tranziens jelenségek széles időtartományon vizsgálhatók. A mérőberendezés felépítése hasonlít a kereskedelemben is kapható ellipszométerekre: egy központi goniométer körül két robosztus, forgatható kar szimmetrikusan helyezkedik el. 


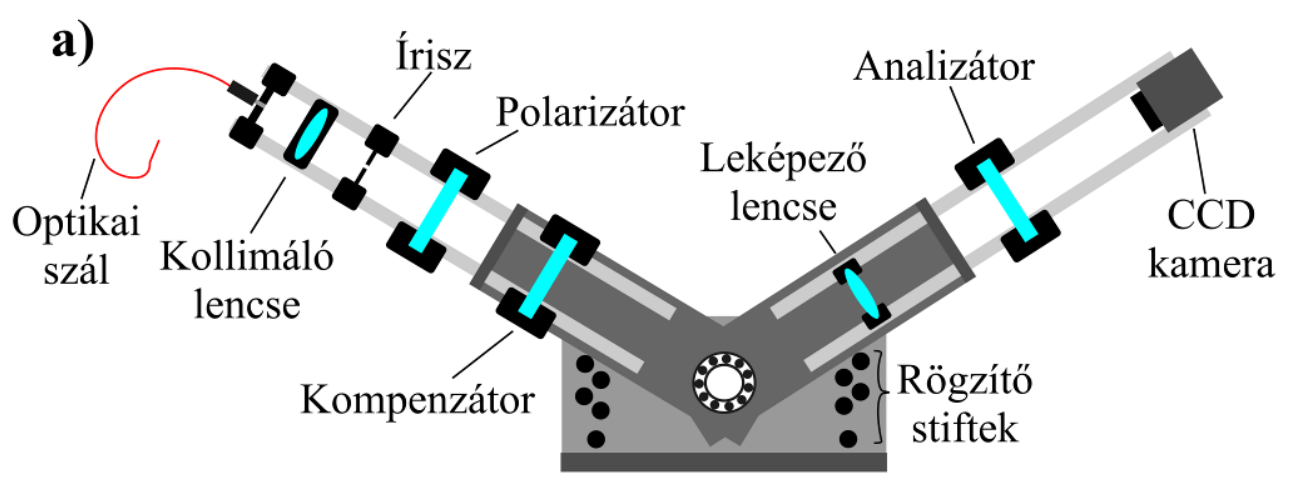

b)
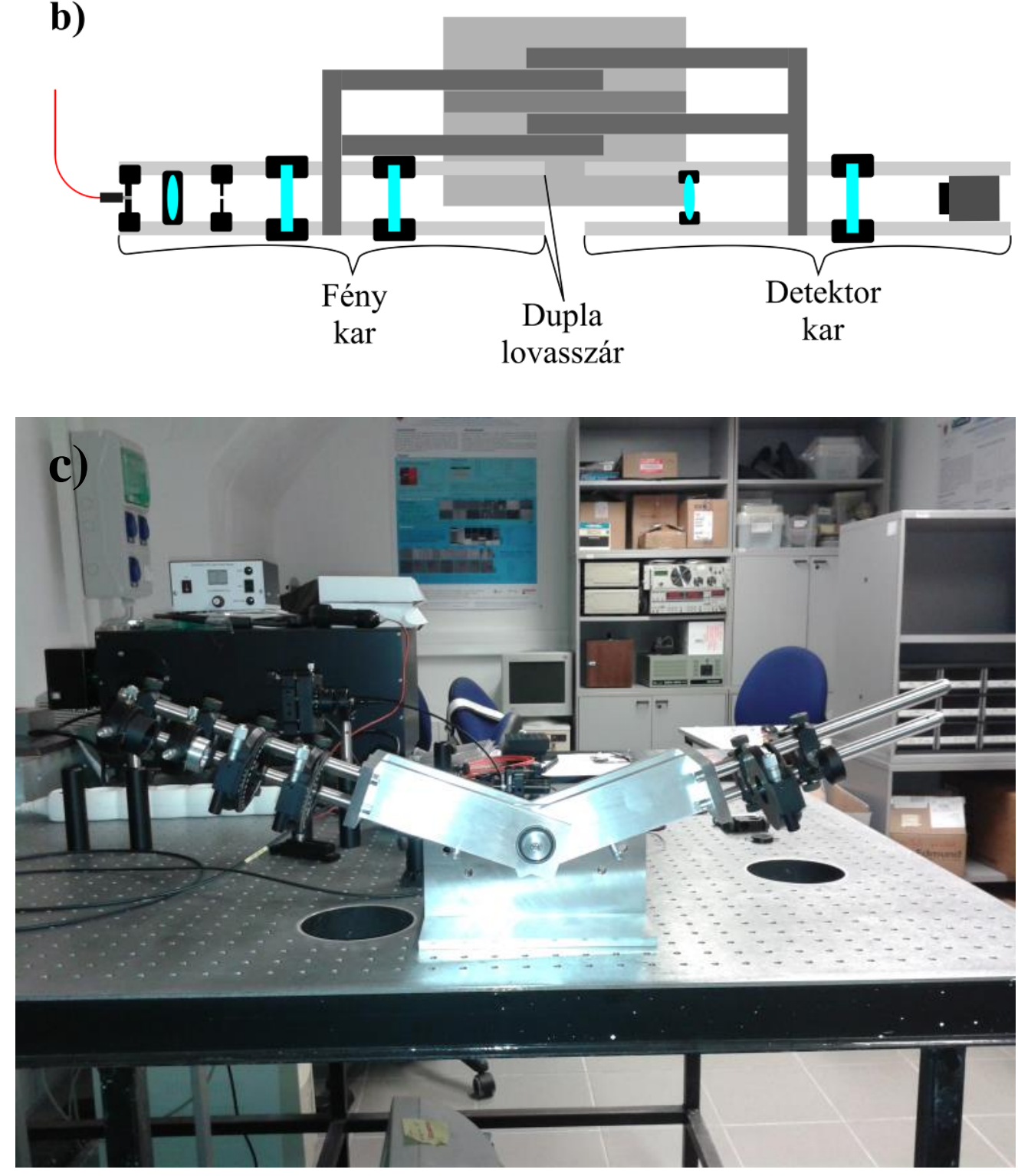

30. ábra: A pumpa-próba null-ellipszométer sematikus ábrája, a) oldalnézetben illetve b) felülnézetben, valamint c) a megvalósitott berendezésröl készült kép. 
Az egyszerübb kezelhetőség érdekében a karok szögét fix értékekre lehet beállítani egy-egy rögzítő stift segítségével. A tervezés során figyelembe vettem, hogy a kísérleteket Si céltárgyakon fogom végezni, így a beállítható beesési szögeket 60 és 75 fok között $\sim 5$ fokonkénti ugrással választottam meg. Mindezek mellett a karok vízszintes pozícióba is helyezhetők, amely az optikai elemek kalibrálása, beállítása szempontjából fontos. A két karon két-két lovasszár található, amelyekre az optikai elemeket azok elfordulását kizárva, diók segítségével lehet rögzíteni. A karonkénti dupla lovasszáras elrendezés biztosítja az optikai elemek stabil rögzíthetőségét, valamint az elemek optikai tengelyre való könnyebb felfüzhetőségét, illetve az optikai tengely mentén való könnyü elcsúsztathatóságot. A goniométer egy robusztus talpazaton foglal helyet, így biztosítva a berendezés stabilitását.

Pumpa-próba kísérletekhez az SZTE Kísérleti Fizika Tanszékén müködő, festék-KrF lézerrendszert használtam. A lézer sajátosságából adódóan [86] kicsatolható a festéklézerrendszer magimpulzusának egy része, amely $498 \mathrm{~nm}$-es hullámhosszal és 0,5 ps-os impulzushosszal rendelkezik. Ezeket használtam próbaimpulzusokként. Az ebből frekvenciakétszerezéssel keltett és erősített UV impulzusok pedig a pumpaimpulzus szerepét töltötték be.

A próbaimpulzus egy optikai késleltető ágon haladt keresztül, amelynek fő eleme egy eltolóra rögzített sarokprizma volt. A sarokprizma elmozdításával lehetett állítani a próbaimpulzusok optikai úthosszát, ezzel a pumpa- és a próbaimpulzus közötti késleltetést, 30 fs-os pontossággal, 0-146 ps-os tartományban. A késleltető ágról készült sematikus ábra a 31. ábra a) részén látható. A késleltetésért felelős rész után a próbaimpulzust egy optikai szálba csatoltam, amely a fényt az ellipszométer karjába továbbította. Azért választottam optikai szálat tükrök helyett, mivel a lineárisan poláros próbaimpulzus a multimódusú optikai szál után depolarizálttá válik, így tetszőleges polarizációs irányt lehetett egy polarizátor segítségével az ellipszométer fényforrás karján beállítani. A másik indok az optikai szál flexibilitása, ami miatt könnyedén lehetett változtatni a beesési szöget, anélkül, hogy a próbanyaláb irányát és a késleltetést módosítani kellett volna. Az ellipszométer fényforrás karjában az optikai szálat elhagyó próbaimpulzust egy gyüjtőlencse segítségével $(f=25 \mathrm{~mm})$ kollimáltam, majd egy íriszen, a polarizátoron illetve egy $\lambda / 4$ es hullámlemezen vezettem keresztül. Ezt követően a nyaláb elérte a mintát, ahonnan a detektorkarba reflektálódott, keresztülhaladva az analizátoron, majd egy lencsén, ami leképezte a minta felületét a CCD detektorra. A minta egy tartóasztalon helyezkedik el, amely függőleges és a beesési síkra merőleges, vízszintes irányban mozgatható. A magasság állításával lehet elérni, hogy 
a minta a goniométer forgástengelyének síkjába helyezkedjen el, így a mintára beérkező és az onnan reflektált nyaláb a detektorkar optikai tengelyén halad tovább. A vízszintes eltolás a mérési pontok precíz beállítása miatt szükséges. A kamera trigger-jelét a lézerrendszer biztosította. A kamera képeit egy általam írt, LabView program mentette a számítógépre. A pumpanyaláb felülröl, merőleges beesés mellett érkezett a mintára.

Az excimer lézer impulzusenergiája a kísérlet során nagymértékben fluktuált (RMS $\approx 10 \%)$, ami az energia folyamatos monitorozását tette szükségessé. Ezt úgy oldottam meg, hogy mind a próbaimpulzus, mind pedig a pumpaimpulzus egy részét kicsatoltam egy üveg, illetve egy kvarclap segítségével (31. ábra). Az UV impulzust egy üveglapra fókuszáltam, és az így létrejött fluoreszcencia fényt pedig egy optikai szálba csatoltam. A kicsatolt próbaimpulzust szintén egy optikai szálba csatoltam. Az optikai szálakon továbbított jeleket egy fókuszáló tükör segítségével a CCD detektorra képeztem le, így a kísérlet során rögzített képek a magimpulzus, illetve az UV impulzus intenzitását is tartalmazták (lásd 34. ábra). Az UV impulzushoz tartozó jelet kalibráltam a közvetlenül a minta felett mérhető energiaértékekhez, így a képeken mért pixelintenzitást a pumpaimpulzus energiájának tudtam megfeleltetni. 
a)

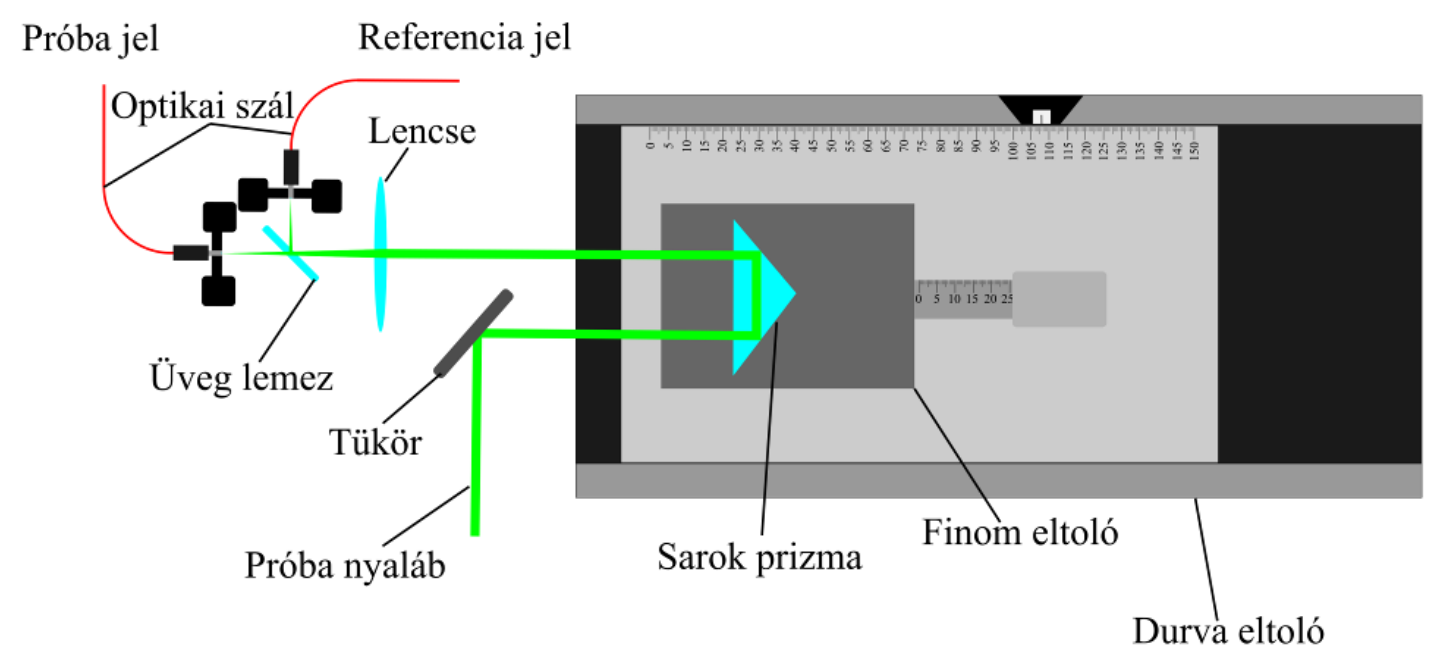

b)

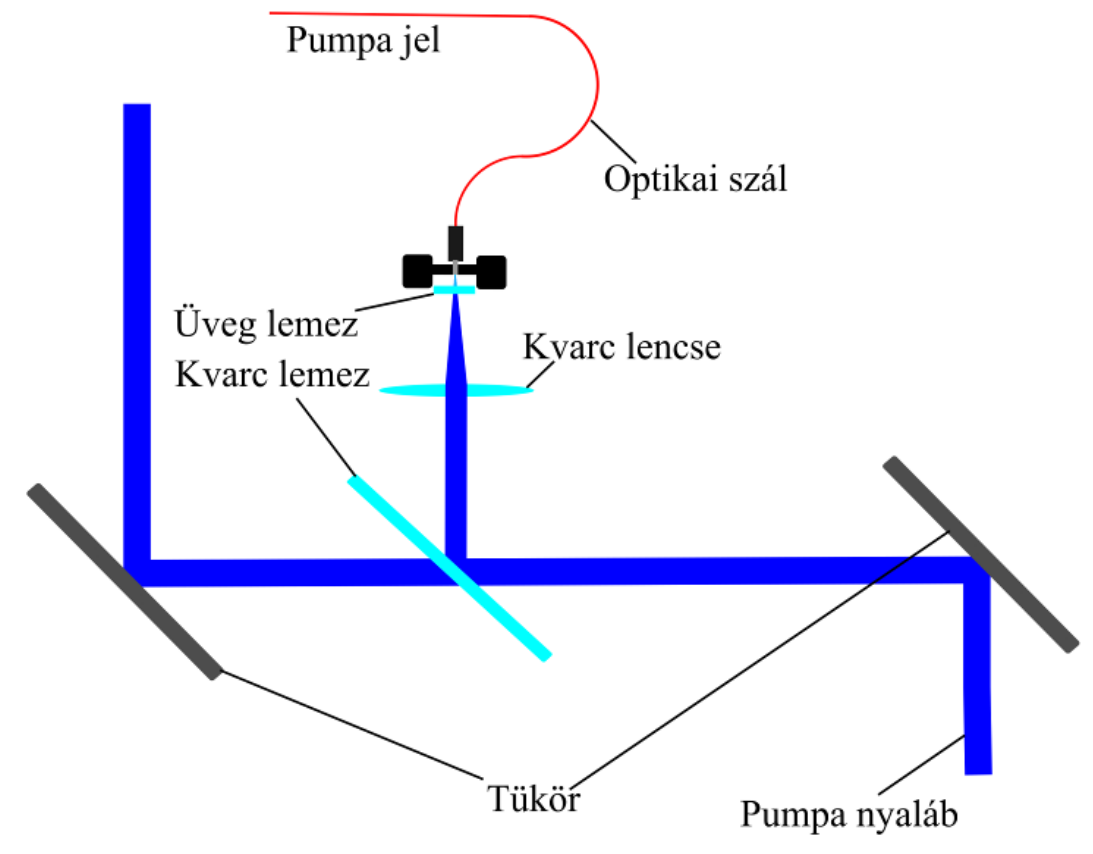

31. ábra: a) a késleltetô ág felülnézeti sematikus ábrája és b) a pumpanyaláb monitorozására használt elrendezés.

\subsubsection{A mérőberendezés és az optikai elemek kalibrációja}

A pumpa-próba kísérletek előtt több kalibrációs mérést is elvégeztem. Ezek az eszköz használhatóságán kívül a beesési szögek pontos meghatározására, valamint az ellipszométerben 
lévő kristálypolarizátorok szögállítóinak nullhibájára, illetve a széles hullámhossztartományon müködő $\lambda / 4$-es lemez fázistolására és a szögállítójának a nullhibájára terjedtek ki.

A kristálypolarizátorok szögállítóinak nullhibáját egy üveglapra, Brewster-szög alatt beeső HeNe lézer 633 nm-es fényének kioltásával határoztam meg. Ehhez azt a fizikai jelenséget használtam ki, hogy a Brewster-szög alatt, üveglapról visszaverődő fény polarizációs iránya a beesési síkra merőleges, így egy ilyen elrendezés egy jól definiált polarizációjú fényt szolgáltat. Ezt a fényt a polarizátorral kioltva meghatározható a szögállító nullhibája.

A kompenzátorként müködő $\lambda / 4$-es lemez fázistolásának meghatározásához a 32. ábrán látható elrendezést építettem fel. Ehhez a méréshez fényforrásként egy folytonos spektrumot biztosító izzólámpát használtam, amely lefedte a 400 nm-től 700 nm-ig terjedő hullámhossztartományt. A mérés során két, egymással $45^{\circ}$-os polarizációs irányt bezáró polarizátor közé helyzetem be a $\lambda / 4$-es lemezt, melyet $5^{\circ}$-okos lépésekkel körbeforgattam és közben spektrálisan bontva mértem az áthaladó fény intenzitás változását.

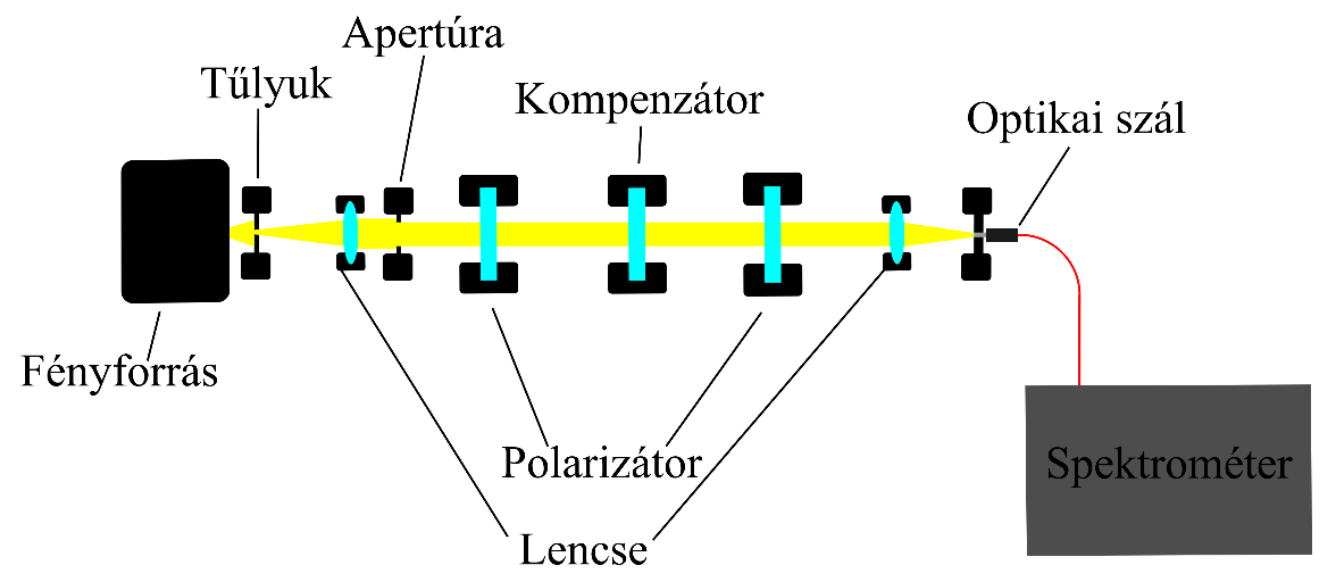

32. ábra: Az akromatikus $\lambda$ 4-es lemez kalibrációjához felépitett kísérleti elrendezés sematikus ábrája.

A fényforrást egy írisz, a kollimáló lencse, majd még egy írisz követte. Ez után helyezkedett el, a két kristálypolarizátor, közöttük pedig a $\lambda / 4$-es lemez. Az elrendezésen áthaladó fényt egy lencsével fókuszáltam egy optikai szál bemenetére, ami továbbította a fényt egy Ocean Optics QE65000 típusú spektrométerbe. Az első polarizátort követően a fény polarizációs iránya vertikális 
volt, a második polarizátor pedig az elsőhöz képest $45^{\circ}$-os szöget zárt be. A kompenzátor fázistolását az 5.2.3.1. fejezetben leírtak alapján határoztam meg. Az optikai rendszert elhagyó fény intenzitásváltozását adott hullámhosszon a (24)-es összefüggés adja meg. Meghatározva a Fourieregyütthatókat, figyelembe véve a polarizátorok azimut szögeit, valamint, hogy egy ilyen elrendezés esetén $\Psi=45^{\circ}, \Delta=0^{\circ}$ (a levegőre vonatkozó ellipszometria szögek), akkor a (25)-(29) összefüggések jóval egyszerübb formát öltenek, és így (30)-(32) összefüggésekből könnyedén meghatározhatók a kompenzátor $\Psi_{c}$ és $\Delta_{c}$ értékei. Az így kapott fázistolást a hullámhossz függvényében 33. ábrán mutatom be.

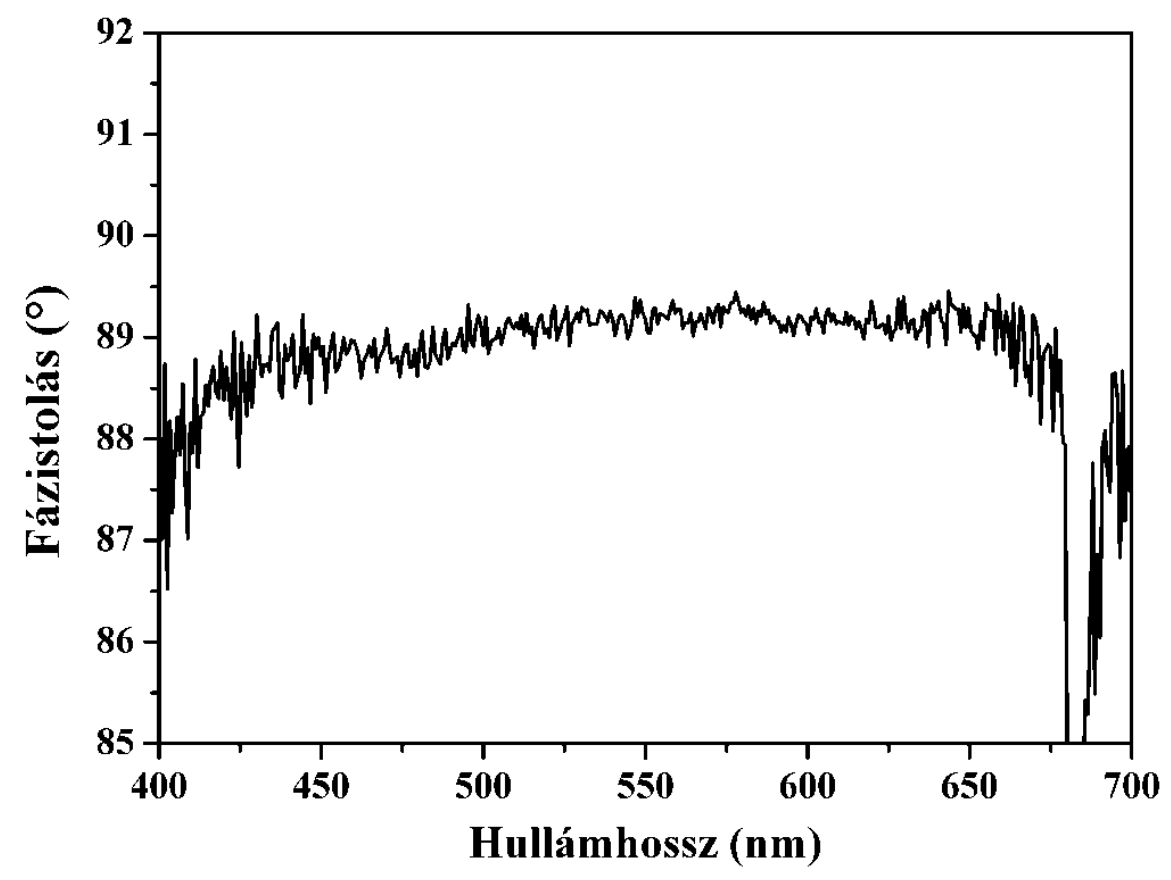

33. ábra: A kompenzátor fázistolása a hullámhossz függvényében.

Ezen adatok ismeretében már el tudtam végezni a null-ellipszométer kalibrációs méréseit. Ezekhez a mérésekhez a 30. ábra a) részén bemutatott elrendezést használtam, azzal a módosítással, hogy a detektorkarban lévő CCD kamera helyett egy Si fotodiódát valamint egy oszcilloszkópot használtam. A He-Ne lézer fényéből egy chopper segítségével, mechanikus módon impulzussorozatot állítottam elő. Mind a négy beállítható szögön végeztem méréseket különböző vastagságú, termális úton növesztett $\mathrm{SiO}_{2}$ mintákon. Null-ellipszometriai mérésekhez az analizátor és polarizátor azimut szögét úgy kell beállítani, hogy a detektált fény intenzitása minimális legyen. A méréseim során azonban nem ezeket a szögeket határoztam meg, hanem a nullhelyzet körül az 
analizátor, polarizátor azimut szögeit szisztematikusan változtatva, és az adott állásnál az intenzitás értékeket rögzítve, egy $5 \times 5$ értékből álló intenzitás térképet határoztam meg. A térképek segítségével pontosabban meg lehetett határozni a nullhelyzetet, a hozzá tartozó analizátor és polarizátor, és így a $\Psi$ és $\Delta$ szögeket. A térképek kiértékeléséhez figyelembe kell venni a 3.2.3.2. fejezetben szereplő (6)-os összefüggést, amely leírja a detektort érő elektromos térerősséget. Ennek megfelelően a térképeken a minimum helyzetekhez tartozó szögeket az alábbi függvény illesztésével határoztam meg:

$$
\begin{aligned}
I(A, P)=a \cdot \mid & \operatorname{tg}\left(A_{0}\right) \cdot \frac{e^{i \Delta_{c} \cdot \operatorname{tg}\left(P_{0}-C\right)+\operatorname{tg}(C)}}{e^{i \Delta_{c} \cdot \operatorname{tg}\left(P_{0}-C\right) \cdot \operatorname{tg}(C)-1} \cdot \cos (A)} \\
& \cdot\left[e^{i \Delta_{c}} \cdot \cos (P-C) \cdot \cos (C)-\sin (P-C) \cdot \sin (C)\right]+\sin (A) \\
& \cdot\left[\sin (P-C) \cdot \cos (C)+e^{i \Delta_{c}} \cdot \cos (P-C) \cdot \cos (C)\right] \mid
\end{aligned}
$$

Ilyen módon meghatározva a nullhelyzethez tartozó analizátor és polarizátor azimut

\begin{tabular}{|c|c|c|c|c|c|c|c|c|c|}
\hline \multirow{2}{*}{$\begin{array}{l}\mathrm{SiO}_{2} \text { réteg- } \\
\text { vastagság }\end{array}$} & & \multicolumn{2}{|c|}{$74.3^{\circ}$} & \multicolumn{2}{|c|}{$68.8^{\circ}$} & \multicolumn{2}{|c|}{$63.5^{\circ}$} & \multicolumn{2}{|c|}{$58.7^{\circ}$} \\
\hline & & $\Psi\left[{ }^{\circ}\right]$ & $\Delta\left[{ }^{\circ}\right]$ & $\Psi\left[{ }^{\circ}\right]$ & $\Delta\left[{ }^{\circ}\right]$ & $\Psi\left[^{\circ}\right]$ & $\Delta\left[{ }^{\circ}\right]$ & $\Psi\left[^{\circ}\right]$ & $\Delta\left[{ }^{\circ}\right]$ \\
\hline \multirow{3}{*}{309.74} & Null-e. & 14,8 & 87,6 & 17,24 & 119,59 & 24,67 & 133,44 & 28,94 & 140,53 \\
\hline & Woollam & 13,1 & 88,8 & 17,8 & 119,5 & 23,1 & 132,4 & 27,2 & 139,2 \\
\hline & Eltérés [\%] & 12,8 & 1,3 & 3,1 & 0,1 & 6,9 & 0,8 & 6,5 & 0,9 \\
\hline \multirow{3}{*}{656.28} & Null-e. & 36,04 & 65,46 & 39,4 & 82,77 & 48,4 & 102,37 & 64,59 & 135,91 \\
\hline & Woollam & 33,6 & 64,0 & 37,8 & 83,8 & 47,5 & 104,7 & 60,9 & 138,1 \\
\hline & Eltérés [\%] & 7,4 & 2,2 & 4,2 & 1,2 & 1,9 & 2,2 & 6,1 & 1,6 \\
\hline
\end{tabular}
szögeket, a (10 a), illetve a (10 b) összefüggések segítségével egyszerủen megadhatók az ellipszometriai szögek. Az így kapott szögeket a VII. táblázat tartalmazza.

VII. táblázat: A null-ellipszométeres elrendezéssel, valamint egy Woollam M2000-F ellipszométerrel meghatározott $\Psi$ és $\Delta$ szögek valamint a két mérési módszer közötti eltérés.

A mintákon a forgó kompenzátoros Woollam M2000-F ellipszométerrel is elvégeztem méréseket, amivel meghatároztam adott minta esetén a rétegvastagságot is. Ezeket az adatokat 
felhasználva egy olyan modellt hoztam létre, ahol a null-ellipszometriából kapott $\Psi$ és $\Delta$ szögeket fix értékekként kezelve a beesési szögekre végeztem az illesztést, így meghatározva egyes esetekben a tényleges beesési szögeket. Ezeket az értékeket a táblázat felső sora tartalmazza. A táblázat továbbá tartalmazza a Woollam ellipszométerrel mért $\Psi$ és $\Delta$ szögeket és a két mérés közötti eltérést százalékos formában. A null-ellipszométerrel mért adatok átlagos relatív eltérése $\Psi$ esetén $6 \%, \Delta$ esetén $1 \%$ alatt volt, így elmondható, hogy ezzel az eszközzel jó pontossággal meghatározhatóak az ellipszometriai szögek.

\subsubsection{A fejezethez tartozó tézisem}

T4: A lézeres felületi kezelések során fellépő tranziens optikai változások mérése céljából megterveztem és megépítettem egy pumpa-próba elrendezésben müködő leképező nullellipszométert. Az elrendezés megépítését követően kidolgoztam egy mérési eljárást az ellipszometriai szögek pontosabb meghatározására. Az eljárás során rögzített kompenzátor szög mellett a polarizátor és analizátor szögállásainak szisztematikus változtatásával intenzitás térképet rögzítettem. A térképek számítógépes kiértékelésével meghatároztam az ellipszometriai szögeket. Az eljárást és a mérési elrendezést termális úton növesztett $\mathrm{SiO} 2$ minták segítségével hitelesítettem. 


\subsection{Tranziens optikai adatok vizsgálata pumpa-próba null-ellipszometriával}

Az előző fejezetben bemutatott null-ellipszométert pumpa-próba elrendezésben is teszteltem. Ezeknél a kísérleteknél a pumpaimpulzus megváltoztatta a minta felszíni hőmérsékletét, aminek az optikai tulajdonságait a próbaimpulzussal vizsgáltam.

A kísérleteim során olyan céltárggyal szerettem volna dolgozni melynek optikai adatai az irodalomból jól ismertek, így a mérések kiértékelése során kapott eredményeket igazolni lehet. Emiatt esett a választásom az egykristályos Si-ra. A céltárgy felületét nem szerettem volna olvadáspontig melegíteni, aminek oka többek között az volt, hogy a mért adatok modellezése során használt Si optikai adatok hőmérsékletfüggése csak $650{ }^{\circ} \mathrm{C}$-ig ismert az irodalomból. A mérési eredmények helyességének igazolásához viszont elengedhetetlen a pontos és valós irodalmi forrás. E miatt a fókuszált pumpaimpulzus fókuszsíkja elé helyeztem a céltárgyat. A minta felszínét a kísérleteim során maximálisan $17 \mathrm{~mJ} / \mathrm{cm}^{2}$-es energiasürüség érte, amely egy nagyságrenddel az ablációs küszöb $\left(170 \mathrm{~mJ} / \mathrm{cm}^{2}\right.$ [88]) alatt van. A pumpaimpulzust egy hengerlencsével gyüjtöttem össze a minta felszínére, így egy $35 \mathrm{~mm} \times 0,7 \mathrm{~mm}$-es megvilágított területet kaptam. A kísérleteim során a próbaimpulzus beesési szöge $68,8^{\circ}$ volt.

\subsubsection{Nyers adatok kiértékelése}

A kísérletek során rögzített képek láthatók a 34. ábrán. A képek kiértékelése során először meghatároztam a sötétjel intenzitását (B mező a 34. ábra a) részén), majd ezt levontam a képekböl. Ezután meghatároztam a pumpaimpulzus energiáját a kicsatolt és a CCD chipre leképezett foltok intenzitása alapján (R UV mező), majd hasonló módon meghatároztam a próbaimpulzus intenzitását (R VIS mező) amivel normáltam a képeket. A pumpaimpulzusok energiájának meghatározása a rögzített képek alapján lehetővé tette, hogy szortírozzam azokat, így vizsgálni tudtam az ellipszometriai adatokat az energiasürüség függvényében is. A normált képekből meghatároztam a pumpaimpulzus által megvilágított részen belül egy kisebb terület átlagos intenzitásértékeit (P jelü mező). Azért nem lehetett a teljes foltot (ahol a pumpa- és a próbaimpulzus átfed) használni, mert a folton belül a két impulzus közti késleltetés változott: mivel a próbaimpulzus nem merőlegesen érkezett a minta felszínére, így az impulzusok a képeken jobbról balra „végigsöpörtek”, tehát az impulzus különböző részei, különböző időpillanatokban 
„tapogatták” le a felszín különböző pontjait. Az időbeli nullahelyzetet a P jelü mezőn határoztam meg, a pumpaimpulzus által a próbaimpulzusban okozott intenzitásváltozás alapján. A késleltetést meghatározó sarokprizma helyzetét úgy állítottam be, hogy gerjesztés időpillanatához tartozó reflexióugrást mutató hely a képeken a $\mathrm{P}$ jelü mezőre essen. Az így meghatározott sarokprizma pozícióhoz viszonyított elmozdítással tudtam a késleltetést a finomeltolóval pontosan beállítani. Így a további mérések során ezen a területen a késleltetés mértéke ismert volt.

A mérések során a $\mathrm{P}$ jelü mező intenzitásértékeit kellett minimalizálni a nullahelyzet meghatározásához, amit az analizátor és polarizátor azimut szögeinek állításával értem el. A 34. ábra a) részén feltüntettem egy olyan képet, ahol az analizátor és polarizátor azimut szögét úgy állítottam be, hogy a nullahelyzet a pumpaimpulzus által megvilágított területre, a b) részén pedig a nem megvilágított területre essen. Az ellipszometriai szögek pontosabb meghatározása érdekében a megvilágított területek nullhelyzetének környezetében az analizátor, polarizátor azimut szögeinek pásztázásával több képet vettem fel. A pásztázás során a szögeket a várható nullhelyzethez képest $\pm 8^{\circ}$-os tartományban változtattam $4^{\circ}$-os lépésközökben. Mindegyik beállításnál legalább 80 db képet rögzítettem az impulzusenergiák fluktuációja miatt. 

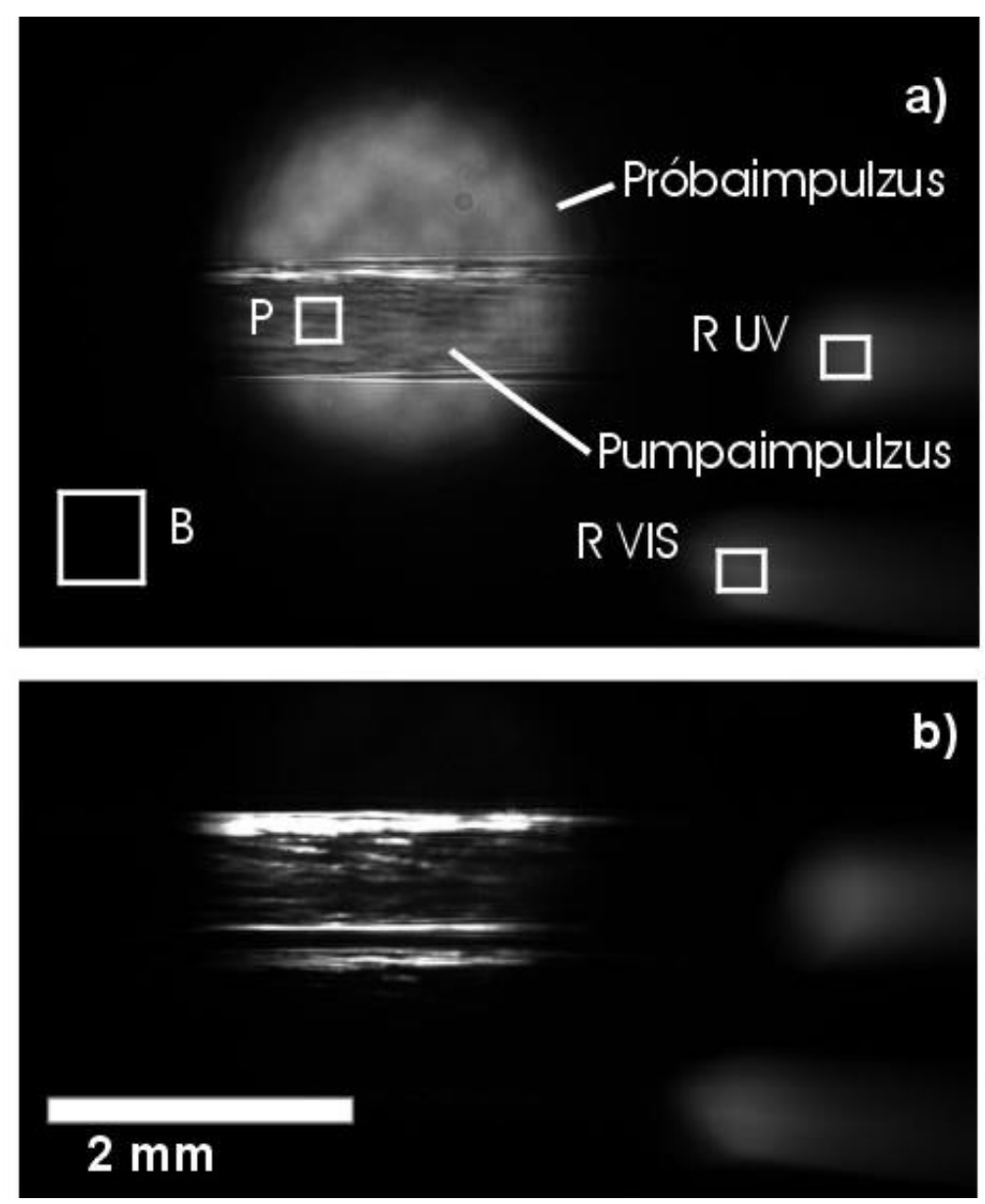

34. ábra: A CCD detektorral rögzített nyers képek az UV impulzussal gerjesztett mintáról. Az a) kép egy olyan esetet mutat, ahol a pumpaimpulzussal gerjesztett rész van kinullázva, a b) pedig egy olyat, amikor a minta nem gerjesztett, viszont a próbaimpulzussal megvilágított része.

A képek fent leírt módszer alapján történő kiértékelése során egy 5×5-ös intenzitás térképet határoztam meg, melynek a tengelyei az analizátor és a polarizátor állásnak feleltek meg. A nullhelyzet meghatározásához 6.4.2. fejezetben bemutatott illesztési eljárást használtam. Egy ilyen térkép látható a 35. ábrán, ahol az a) rész egy pumpaimpulzussal nem megvilágított, b) rész pedig egy pumpaimpulzussal megvilágított területröl készült, úgy, hogy a két impulzus közötti késleltetés 25 ps volt. Az illesztések alapján a $\Psi$ és $\Delta$ szögek meghatározásának pontossága $0.6^{\circ}$ volt. 8 különböző késleltetés $(2,5,15,25,50,75,100$ és 146 ps) esetén vettem fel az analizátor-polarizátor térképeket, mely segítségével nyomon tudtam követni a relaxáció folyamatát az UV lézeres gerjesztést követően. 


\subsubsection{Eredmények}

A 35. ábra a), illetve b) részén látható térképek jól mutatják, hogy jelentős eltérés adódik a minimumhelyzetekben a megvilágított és a nem megvilágított területek között. 25 ps-os késleltetés esetén az analizátor szögében $2,5^{\circ}$, míg a polarizátor szögében $2^{\circ}$ különbséget tapasztaltam.

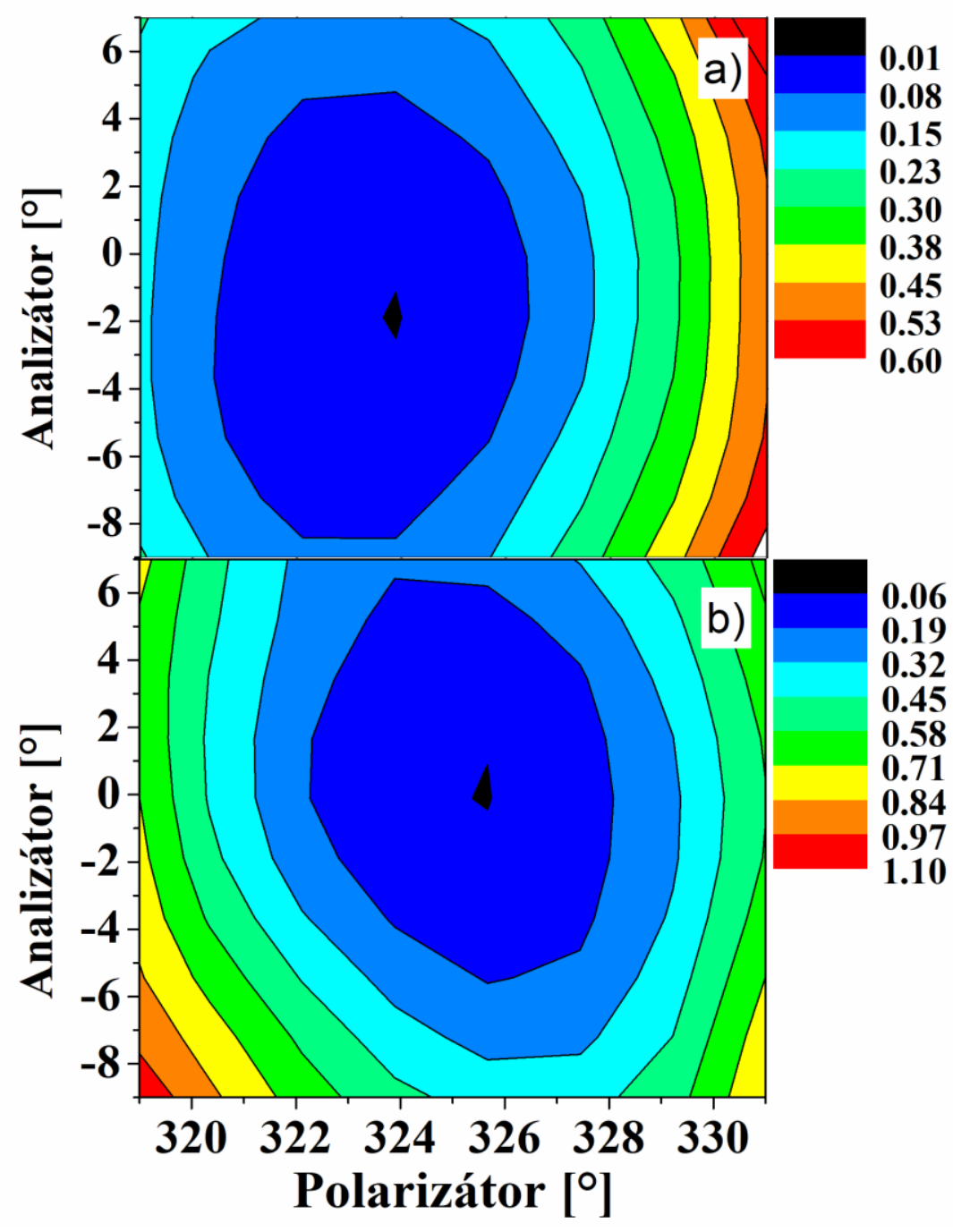

35. ábra: a) Pumpaimpulzussal nem megvilágitott, és b) egy megvilágított területen mért analizátor-polarizátor intenzitás térkép.

Átszámolva ezeket $\Psi$ és $\Delta$ értékekre jelentős eltérést kaptam a megmunkálatlan $\left(\Psi=17.3^{\circ}\right.$ és $\Delta=174.3$ ) és a megmunkált minta esetén ( $\Psi=18.6^{\circ}$ és $\left.\Delta=170.4^{\circ}\right)$. A megmunkálatlan szilícium 
ellipszometriai szögeit egy Woollam M2000-F típusú ellipszométerrel is megmértem, mely jó egyezést adott ( $\Psi=17.7^{\circ}$ és $\left.\Delta=173.9^{\circ}\right)$ a null-ellipszométerrel mért adatokkal.

A különböző késleltetések esetén kapott ellipszometriai szögek a késleltetés függvényében a 36. ábrán láthatóak.

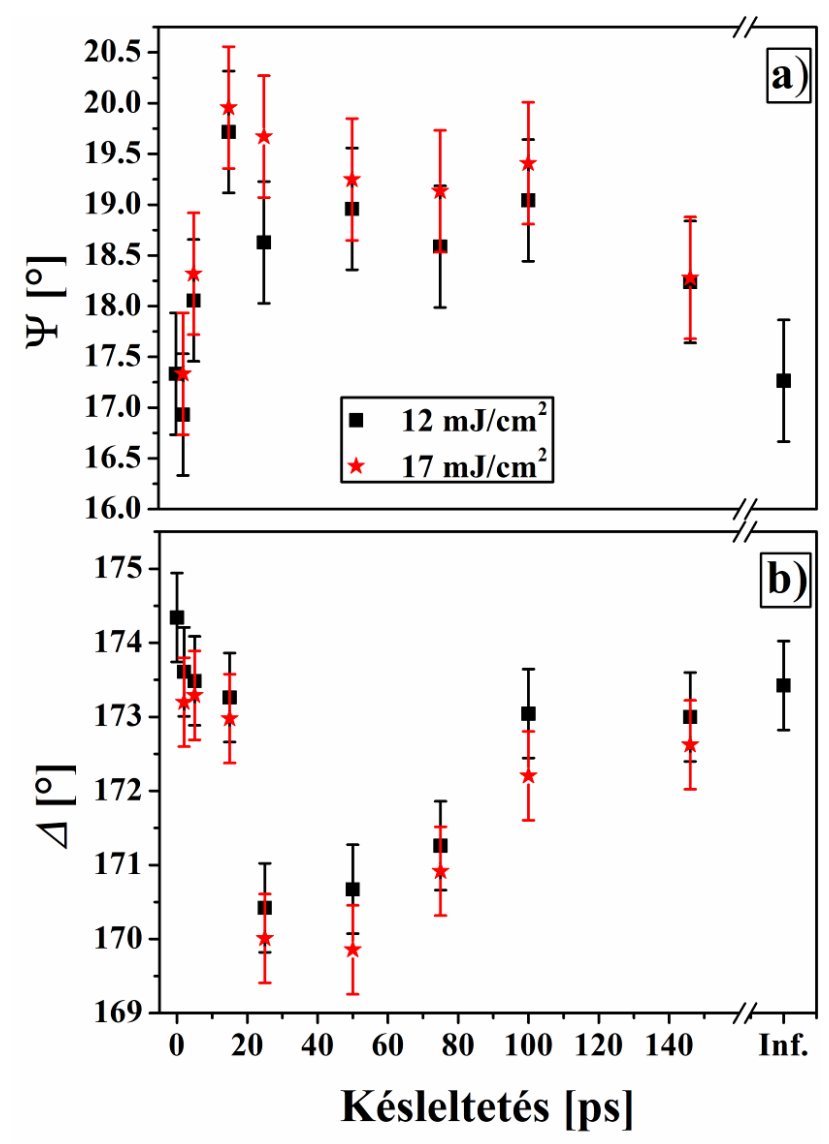

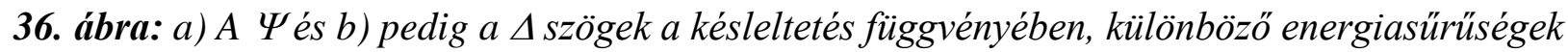
esetén.

Az ábrán jól látható, hogy 10 ps-nál kisebb késleltetések esetén mindkét ellipszometriai szög a megmunkálatlan szilíciumhoz tartozó értékektől alig tér el. A késleltetést tovább növelve hirtelen változás mutatkozik. A mért adatsorok eltérő késleltetések esetén érik el az extrémumukat. $\Psi$ értékében hirtelen növekedés tapasztalható, melynek $20^{\circ}$-os maximális értékét 15 ps-os késleltetés esetén éri el. A $\Delta$-ban 25 ps-os késleltetés esetén tapasztaltam a legkisebb értéket, amely $\sim 170^{\circ}$ volt. Nagyobb késleltetések esetén a mért ellipszometriai szögek megközelítik a megmunkálatlan 
Si esetén mért értékeket (az ábrán 0 ps-os késleltetésnél tüntettem fel ezeket), azonban a legnagyobb érték esetén sem érik azt el, a $\Psi \sim 18^{\circ}$-os, a $\Delta$ pedig $\sim 173^{\circ}$-os értéket vesz fel. Néhány másodperces késleltetést alkalmazva az értékek már jó egyezést mutatnak a megmunkálatlan Si-on mért értékekkel, amely jól jelzi, hogy a felület reverzibilis módon volt gerjesztve. Nagyobb energiasűrüség esetén a mért ellipszometriai szögek egyértelmű változást mutatnak, a $\Psi$ értéke nő, míg a $\Delta$ értéke csökken, átlagosan $0,4^{\circ}$-al a $17 \mathrm{~mJ} / \mathrm{cm}^{2}$-es esetet a $12 \mathrm{~mJ} / \mathrm{cm}^{2}$-es esettel összehasonlítva.

A mérésekből kapott eredmények modellel történő leírásához a 37. ábrán látható rétegrendszert alkalmaztam.

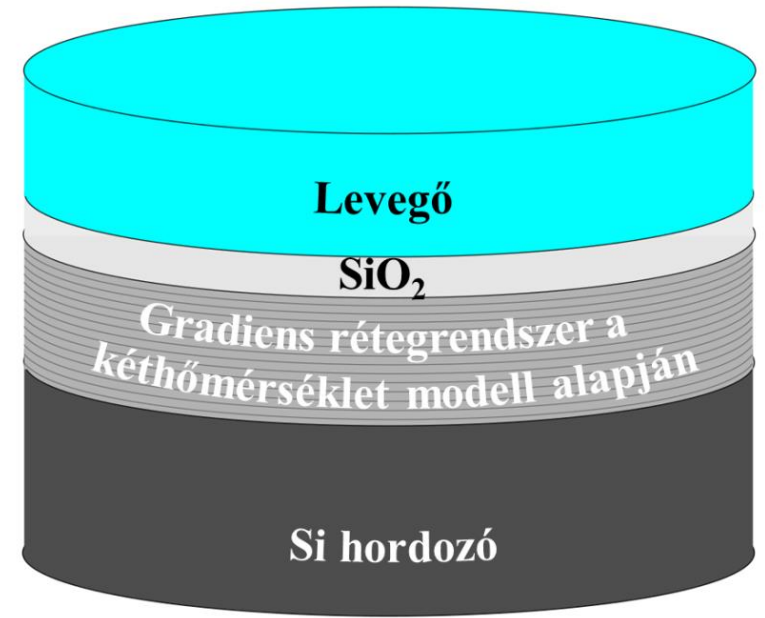

37. ábra: A null-ellipszometriai mérések során használt modell felépitése.

A felszínen egy $2 \mathrm{~nm}$ vastag, natív $\mathrm{SiO}_{2}$ réteg van, amely alatt található a Si hordozó. A lézerimpulzus hatására a hordozó felszínéhez közel mind a hőmérséklet, mind az elektronkoncentráció változására számíthatunk, ezen hatások mélységbeli leírásához a hordozó tetején egy vékonyabb réteget 500 alrétegre osztottam. Ezekben az alrétegekben határoztam meg az anyag optikai tulajdonságait a hőmérsékletfüggő Si optikai adatok alapján, a szabad töltéshordozók jelenléte okozta változásokat pedig a Drude-modell segítségével vettem figyelembe. Az adott alréteg hőmérsékletét és a Drude-modellhez szükséges elektronkoncentrációt kéthőmérséklet modell segítségével határoztam meg. A kéthőmérséklet modellszámolások alapján azt tapasztaltam, hogy a hőmérséklet és az elektronkoncentráció változás $2 \mu \mathrm{m}$-nél vékonyabb 
rétegben valósul meg, így az ellipszometriai modellben az alrétegek összvastagságát $2 \mu$ m-nek választottam.

A kéthőmérséklet modellt a 3.2.4. fejezetben részletesen tárgyaltam. A bemutatott csatolt differenciálegyenlet rendszert a COMSOL Multiphysics modellező program segítségével 1 dimenziós esetben oldottam meg. A modellezés során az alábbi határfeltételeket használtam a hőmérsékletre vonatkozóan: $T_{e}(x, t=0)=T_{p h}(x, t=0)=300 \mathrm{~K}$, a töltéshordozó koncentráció pedig: $N(x, \quad t=0)=10^{12} 1 / \mathrm{cm}^{3}$. Neumann-határfeltételt használtam az 1D-s objektum határain a hőmérsékletek, illetve az elektronkoncentráció leírásához. A felületeken átáramló lézerintenzitásokat Dirichlet-féle határfeltételek segítségével vettem figyelembe: $I=I(t)(\mathrm{x}=0)$ és $I=0(\mathrm{x}=2 \mu \mathrm{m})$.

A 38. ábrán látható az elektronkoncentráció és a rácshőmérséklet mélységbeli eloszlása a kísérletek során alkalmazott késleltetések esetén. A számolások során a 0 ps-hoz tartozó időpillanatban érkezett meg az UV lézerimpulzus a minta felszínére, így az ábrázolt göbékhez tartozó időpontok megegyeznek a kísérletek során használt késleltetésekkel. Az ábrázolt görbék $17 \mathrm{~mJ} / \mathrm{cm}^{2}$-es energiasürüséghez és 4 ps-os elektron-fonon relaxációs időhöz tartoznak. Az ábrán jól látható, hogy mindegyik késleltetési időnél a legnagyobb elektronkoncentráció és rácshőmérséklet a felületen tapasztalható. A késleltetési idő növelésével azt tapasztaltam, hogy a felszínen az elektronkoncentráció csökken a rácshőmérséklet viszont csak a 15 ps-os esetben éri el maximális értékét. Mindkét számolt érték a mélység függvényében monoton csökkenő tendenciát mutat. Az elektronkoncentráció mélységbeli eloszlása az 5, 15, 25 ps-os késleltetések esetén jól láthatóan egyre lankásabb lefutást mutat, amiből azt a következtetést vontam le, hogy a töltéshordozók a mélyebb régiókba diffundálódnak növelve ott a rácshőmérsékletet. 

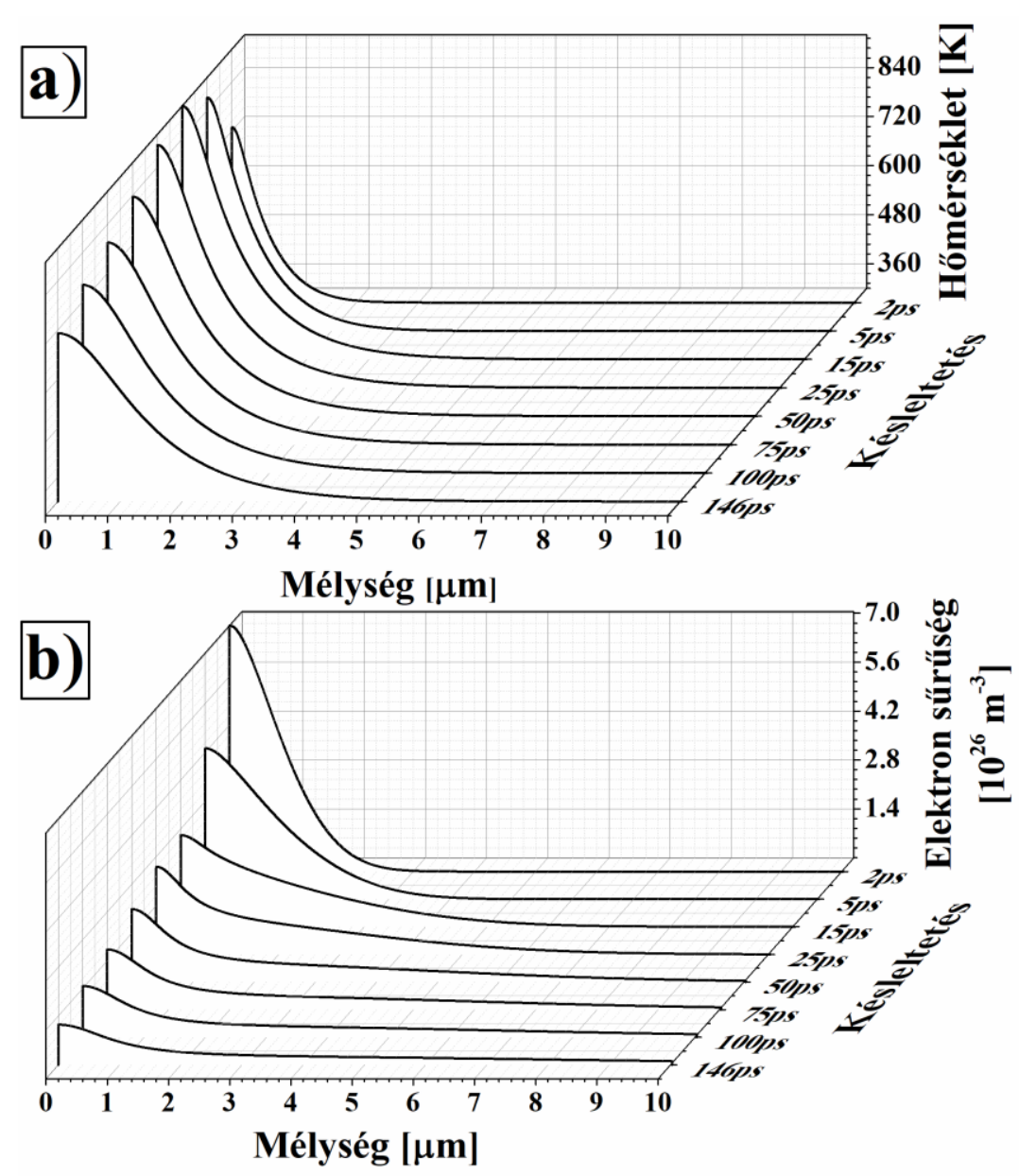

38. ábra: a) Az elektronkoncentráció, b) pedig a rácshömérséklet mélységbeli eloszlása a különbözö késleltetési idöknél.

A két modell kombinációja (2TM + ellipszometria) során először az elektron-fonon relaxáció idejének hatását vizsgáltam, melynek értékét 2 és 5 ps között változtattam. Az így kapott $\Psi$ és $\Delta$ értékek a késleltetés függvényében a 39. ábra a) és c) részén láthatóak. Mindegyik görbe jól követi a mért értékeknél tapasztalt tendenciát. A $\Psi$ értéke esetén egy gyors növekedés figyelhető meg, melyet egy lassan lecsengő szakasz követ. A $\Delta$-ban hasonló, de ellentétes tendencia mutatkozik. Látható, hogy a relaxációs idő változtatása nemcsak a görbék szélsőértékének pozícióját, de annak intenzitását is befolyásolja. Növekvő időállandó esetén az ellipszometriai szögekben bekövetkező változás kisebb és a lefutásuk nagyobb időskálán történik. A szimuláció alapján a 4 ps-os elektronfonon relaxációs idő (vastagított piros görbe) adta vissza a legjobb egyezést a mérési eredményekkel, így a későbbi számolások során ezt az értéket vettem alapul. Azonban mindkét ellipszometriai szög esetén a mért és a számolt értékek között eltérést tapasztaltam. Mivel az 
impulzus energiaeloszlása a megvilágított tartományon belül inhomogén lehet így megvizsgáltam, a számolások során használt energiasűrüségek hatását is. Az eredmények a 39. ábra b) és d) részein láthatóak.
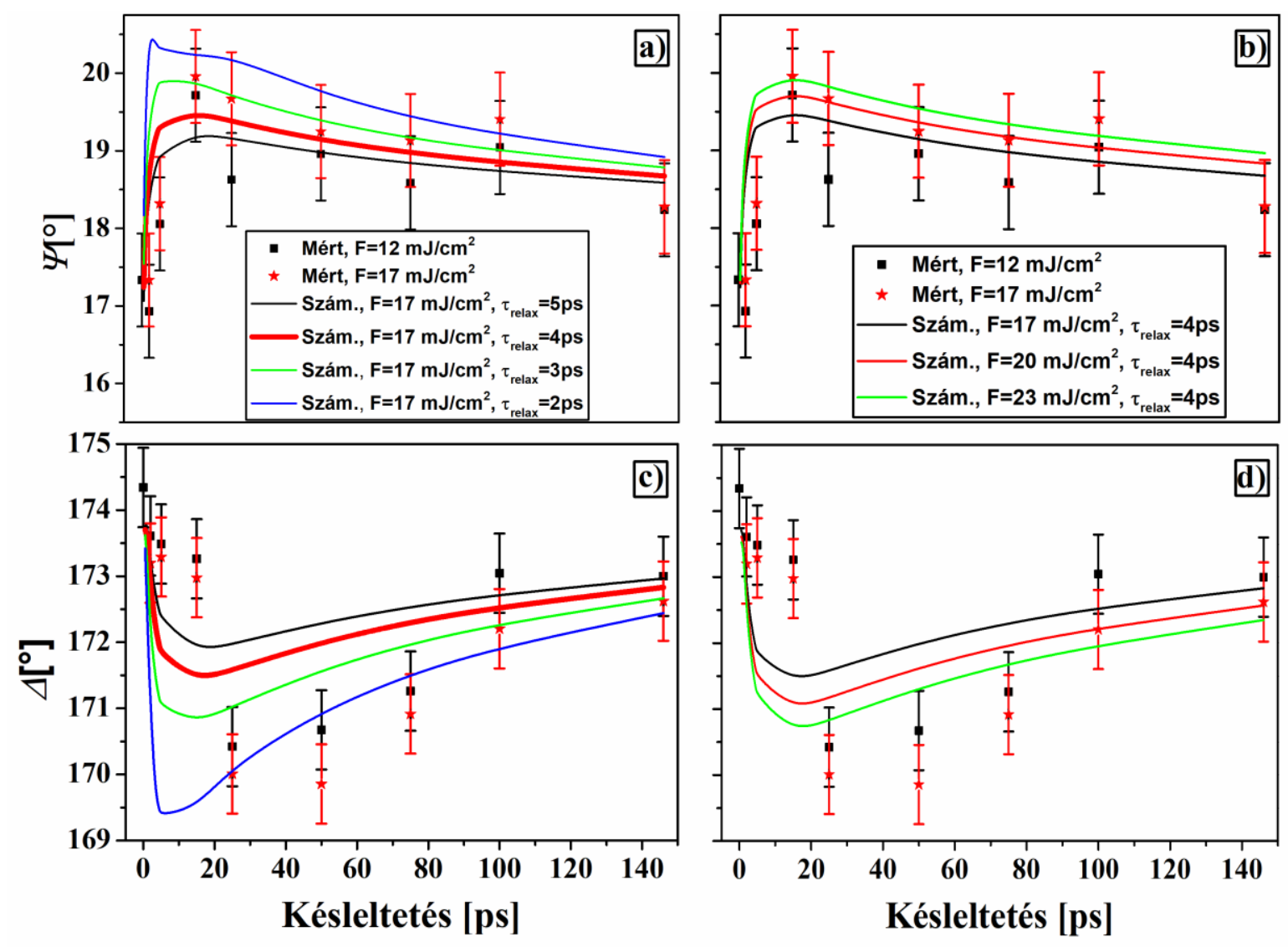

39. ábra: Mért és számolt $\Psi$ és $\Delta$ értékek különbözö késleltetések mellett. Az a) illetve c) ábrák a modellezett $\Psi$ és $\Delta$ értékeket mutatják különbözö relaxációs idö esetén, $17 \mathrm{~mJ} / \mathrm{cm}^{2}$ energiasürüséggel számolva. A b) és d) ábrák a különbözö energiasürüségek hatását mutatják a $\Psi$ és $\Delta$ szögek értékeire, 4 ps-os relaxációs idö esetén.

Jól látható, hogy kicsivel nagyobb energiasürüségek jobban visszaadják a mért értékeket. Továbbá az is látható, hogy a mérési eredményekkel összhangban a modellezés is azt mutatja, hogy az energiasürüség növelésével az ellipszometriai szögekben a referenciához képest tapasztalt eltérések növekszik. 


\subsubsection{A fejezethez tartozó tézisem}

T5. A pumpa-próba null-ellipszométer segítségével méréseket hajtottam végre Si céltárgy felületén. A kísérletek során szub-pikoszekundumos pumpa $(\lambda=248 \mathrm{~nm})$, illetve próba $(\lambda=496 \mathrm{~nm})$ impulzusok felhasználásával meghatároztam a szilícium $\Psi$ és $\Delta$ szögeinek tranziens jellegü változását a próbaimpulzus 2 ps és 146 ps közötti késleltetésével. Kis késleltetéseknél $\Psi$ értékében növekedést, $\Delta$ érétkében csökkenést tapasztaltam. A $\Psi$ szög maximális értékét 15 ps-os késleltetés esetén érte el, a $\Delta$ szög 25 ps-ig csökkent. A késleltetések további növelésénél a mért adatok fokozatosan visszatértek a kezdeti értékhez. Az ellipszometriai szögek változásának leírására a kéthőmérséklet modell segítségével kiszámoltam a besugárzás során kialakuló hőmérséklet időbeli és térbeli eloszlását különböző relaxációs idők esetén. A hőmérséklet és elektronsűrüség változás figyelembe vételével megalkottam egy ellipszometriai modellt, mely $17 \mathrm{~mJ} / \mathrm{cm}^{2}$ energiasürüség mellett 4 ps relaxációs idő választása esetén jól leírta az ellipszometriai szögek tranziens változását. 


\section{Magyar nyelvü összefoglaló}

A lézeres anyagmegmunkálás napjainkban bevett gyakorlattá vált az ipar és a tudomány számos területén. Lézereket használnak anyagok fúrására, vágására, hegesztésére, de akár kontrolált szerkezeti változásokat is elő tudnak idézni a segítségükkel, úgymint keményítés, kristályosítás, vagy akár amorfizálás. Noha ezen eljárások fizikai hátterét régóta vizsgálják, napjainkban is intenzív kutatás övezi a lézer-anyag kölcsönhatásokat. Ennek oka a besugározni kívánt anyagok széles köre, valamint a lézerek fejlődése, amelyek újabb és újabb lehetőségeket teremtenek. Ezen szerkezeti változások nyomon követésére több vizsgálati módszer is létezik, azonban előszeretettel használnak roncsolásmentes eljárásokat. Dolgozatomban a különböző lézerekkel megmunkált minták vizsgálata során két ilyen mérési módszert, a Ramanspektroszkópiát és spektroszkópiai ellipszometriát is használtam. Ez a két technika eltérő optikai elv alapján képes a felületek jellemzésére. A két eljárást párhuzamosan használva pontosabb információt kaphatunk a minta tulajdonságairól.

Lézeres felületmegmunkálással a szerkezeti változások mellett az anyagok felületi tulajdonságait is befolyásolhatjuk, úgymint a keménység, nedvesítési- és optikai tulajdonságok. Ezeket a változásokat gyakran a felszínen létrehozott periodikus struktúrákkal idézik elö. A lézer indukálta felületi periodikus struktúrák, angolul LIPSS (Laser Induced Periodic Surface Structure) kialakulásának fizikai hátterét napjainkban is intenzíven kutatják. Noha számos, különböző paraméterek hatását vizsgáló impulzuslézeres megmunkálással kapcsolatos kísérletet végeztek már, az irodalomban nem található olyan, amely adott lézertípus használata során kizárólag az impulzushossz nagyságrendekkel történő megváltoztatása mellett vizsgálta volna a létrehozott struktúrákat.

Az eddigiekben említett lézeres anyagmunkálási eljárások alkalmazásakor fontos paraméter a megmunkálandó anyag optikai tulajdonságainak, úgymint reflexiójának, abszorpciójának, törésmutatójának változása. Ezek a paraméterek a lézerimpulzus beérkezése közben, tranziens módon változnak, amit a lejátszódó jelenségek pontosabb megértése céljából fontos vizsgálni. Ilyen gyors, szub-pikoszekundumos változások vizsgálatára kiváló lehetőség a pumpa-próba módszer, amely során a pumpa lézerimpulzus által létrehozott változást az időben késleltetett 
próbaimpulzussal tapogatjuk le. Ezt a módszer az ellipszometriai méréstechnikával vegyítve kiváló lehetőséget kapunk tranziens optikai jellemzők vizsgálatára.

Doktori munkám során az volt a célom, hogy in-situ és ex-situ módszerekkel széleskörüen megvizsgáljam különböző impulzusüzemü lézerek által üvegszerü szén, valamint szilícium céltárgyak felszínén létrehozott változásokat. Munkám első felében üvegszerủ szén felületén különböző lézerekkel létrehozott változásokat kívántam nyomonkövetni Raman-spektroszkópiával és spektroszkópiai ellipszometriával. A célom az volt, hogy kidolgozzak egy olyan kiértékelési módszert, mely segítségével leválasztható a hordozó Raman-jelével terhelt Raman-spektrumból csak a vékonyrétegre jellemző spektrum. Ezt felhasználva a két technika segítségével a különböző nanoszekundumos, valamint szub-pikoszekundumos lézerek által létrehozott strukturális változások feltérképezését tüztem ki célul.

Munkám második részében célul tűztem ki üvegszerủ szén felületén periodikus struktúrák létrehozását. Vizsgálni szerettem volna a lézerimpulzusok impulzusidejének változtatása esetén létrehozott periodikus struktúrák paramétereit. Ezek ismeretében meg szerettem volna határozni a struktúrákat létrehozó fizikai folyamatokat.

Következő munkám során az eddigi ex-situ vizsgálati módszereimet in-situ eljárásra kívántam váltani. Ezeknek a kísérleteimnek a célja a lézeres felületkezelés során végbemenő optikai jellemzők tranziens változásának meghatározása volt, melyhez ellipszometriai méréseket terveztem véghezvinni. Ehhez pumpa-próba elrendezésben müködtetett null-ellipszometriai elrendezést megtervezését és használatát tüztem ki célul.

Értekezésem eredményeit bemutató fejezet első részében bemutatok egy általam kidolgozott kiértékelési módszert, melyet olyan felületi vékonyréteg Raman-spektroszkópiai mérései esetén lehet használni, ahol a mért spektrumban a vékonyrétegre vonatkozó jelet a hordozó jele is terheli. $\mathrm{Az}$ általam megadott kiértékelési eljárás során a Raman-spektrumok csúcsainak illesztését a következők szerint végeztem el: a független mérésből meghatároztam a hordozó Ramanspektrumát, melyet a megfelelő Gauss-függvények segítségével csúcsokra bontottam. A vékony réteg - hordozó rendszeren mért spektrum csúcsokra bontásakor a hordozóra jellemző spektrum paramétereit rögzítettem és egy súlyfaktornak nevezett változóval beszorozva konstans tagként vettem figyelembe. Így a spektrumból sikeresen le tudtam választani csak a rétegre jellemző 
Raman-csúcsokat. A bevezetett súlyfaktor a hordozó Raman-jelének gyengülését írja le, így ez a szorzófaktor kapcsolatban áll a réteg abszorpciós tulajdonságával. A módszer validálásához nanoszekundumos, valamint szub-pikoszekundumos excimer, illetve Nd:YAG lézerrel munkáltam meg üvegszerü szén mintákat és végeztem rajtuk Raman-spektroszkópiai, valamint spektroszkópiai ellipszometriai méréseket. A spektrumok illesztését követően kiszámoltam az említett súlyfaktort, amely a legtöbb minta esetén egyértelmü összefüggést mutatott az ellipszometriai mérésekből kapott rétegvastagságokkal és abszorpciós tulajdonságokkal. Ezek alapján megállapítottam, hogy az általam kidolgozott eljárás használható olyan Ramanspektroszkópiai mérések kiértékelése során, ahol tisztán a vékonyrétegre vonatkozó Ramanspektrum meghatározása a cél.

A második részben bemutatom, hogy a kidolgozott illesztési eljárást alkalmazva milyen információk határozhatók meg excimer, valamint Nd:YAG lézerekkel kezelt mintákon létrejött vékonyrétegek esetén. A rétegek Raman-spektrumai alapján meghatároztam a szénre jellemző D és $G$ csúcsok intenzitásarányát, félértékszélességüket, valamint a $G$ csúcs pozícióját. Az ellipszometriai mérésekből megadtam a felületi módosított réteg vastagságát, törésmutatóját, valamint extinkciós együtthatóját. Mivel a megmunkáláshoz használt lézerek paraméterei, úgymint hullámhossza, impulzushossza nagymértékben eltért, a mérési eredményeimet a térfogati energiasűrüség függvényében interpretáltam. Ezt a módszert témavezetőim korábbi munkái során sikeresen használták hasonló esetekben. A térfogati energiasürüség nem más, mint a felületi energiasürüség és a minta abszorpciós állandójának szorzata, az adott lézer hullámhosszán. Ez a változó tartalmazza azt, hogy a lézer által közölt energia mekkora térfogatban nyelödik el. A kapott eredmények alapján megállapítottam, hogy a kezelt minták felületén 2-90 nm vastagságú módosult vékonyréteg alakult ki, mely az üvegszerü szénhez képest rendezetlenebb struktúrával rendelkezik. Raman-spektroszkópiai méréseim rávilágítottak arra, hogy a kialakult réteg szerkezetét tekintve közel áll a nanokristályos grafithoz. Elektronmikroszkópos felvételek megmutatták, hogy a Nd:YAG lézerrel kezelt minták esetén a felületen olvadás nyomai láthatók, míg az excimer lézerekkel kezelt mintáknál ezt nem tapasztaltam. Ennek okát az eltérő ablációs folyamatokkal magyaráztam. Az excimer lézerek esetén kétfotonos abszorpcióval fotokémiai abláció is megvalósulhat. A Nd:YAG lézer esetén azonban ez nem teljesül, így ott tisztán termális úton játszódik le az abláció folyamata. 
Eredményeim harmadik fejezetében üvegszerü szén céltárgyak felszínén periodikus struktúrák kialakítására vonatkozó eredményeimet tárgyalom. Üvegszerű szén minták felszínén sugároztam be infravörös (Ti:Zafír), valamint ultraibolya (festék-KrF) impulzusokkal. Kísérleteim során az impulzusok hosszát, valamint számát változtattam. A megmunkálás eredményeként a felületen periodikus struktúrák jöttek létre, melyeket elektronmikroszkóp segítségével vizsgáltam. A struktúrák kvantitatív és kvalitatív jellemzésére a képeket Fourier-transzformációs eljárással értékeltem ki.

Infravörös lézeres kezelés esetén 35 fs és 200 ps között, nagyságrendi lépésekkel változtattam az impulzusok hosszát. A 30 ps-os és annál hosszabb infravörös impulzusok esetén az elektronmikroszkópos felvételek olvadékcseppek megjelenését mutatták. Ez alapján az üvegszerü szén termalizációs idejét néhány ps-os időintervallumra tettem. Megállapítottam, hogy a minta felszínét ultrarövid lézerimpulzusokkal megmunkálva a termalizációs időnél rövidebb impulzusok esetén sub-200 nm-es periodikus távolságokkal rendelkező struktúrák jönnek létre. A termalizációs időnél hosszabb impulzusok esetén a lézer hullámhosszának tartományába eső struktúratávolságú mintázat jelentkezik. Ezek alapján azt a megállapítást ettem, hogy a nagyobb periódusú struktúrák megjelenését az olvadékban létrejövő kapilláris hullámok okozhatják. A 200 ps-os minta esetén az egész területről felvett átnézeti kép megmutatta, hogy a minta közepén az említett nagyobb távolsággal rendelkező struktúrák jelennek meg, azonban a minta széle felé ezt felváltják a kisebb távolsággal jellemezhetők. Ez alapján arra a következtetésre jutottam, hogy a struktúrák kialakulásában fontos szerepe van a lokális energiasürüségnek is, ami meghatározza az olvadás megjelenését. Mindegyik impulzushossz esetén a struktúrák iránya a polarizációs irányra meröleges volt.

Ultraibolya lézeres kezelés esetén 250 fs és 2,1 ps között változtattam az impulzusok időbeli hosszát. A minták felszínén szintén tapasztaltam a hullámhossz tartományába eső és annál jóval rövidebb struktúrák megjelenését is. A szub-100 nm periódusú struktúrák irányultsága a polarizációs irányra merőleges, a hullámhosszal összemérhetőké azonban azzal párhuzamos volt. Ezek a struktúrák az impulzushossztól függetlenül mindegyik minta esetén megjelentek.

Az elektronmikroszkópos vizsgálatok mellett Raman-spektroszkópiai méréseket is végeztem minden esetben, amely megmutatta, hogy a felszínen egy módosított vékonyréteg alakul ki a lézer hullámhosszától és impulzushosszától függetlenül. 
Az eredményeimet tárgyaló fejezet következő részében bemutatom az általam tervezett és megépített leképező null-ellipszométert, melyet ultragyors, tranziens optikai adatok mérésének céljából terveztem. A null-ellipszométer a legegyszerübb ellipszométerek közé tartozik, mely a mintáról reflektálódó fény kioltásán alapszik. Ehhez az ellipszométer fénykarjában elhelyezett negyedhullámlemezt, illetve polarizátort, valamint a detektor karban lévő polarizátort használunk. A pontosabb mérések elvégzése érdekében kidolgoztam egy eljárást, amely segítségével precízebben meg tudtam határozni adott minta esetén a mintáról reflektálódó fényimpulzusok kioltásához tartozó polarizátor szögállásait. Az eljárás lényege az, hogy a nullhelyzet várható értéke körül a polarizátorok szisztematikus változtatásával egy intenzitás térképet vettem fel, melyet egy általam írt számítógépes algoritmussal értékeltem ki. Az eszközt úgy terveztem meg, hogy 4 különböző beesési szögön lehessen használni ellipszometriai mérésekhez. A mérési pontosság meghatározása, valamint az eszköz kalibrálása céljából termális úton növesztett $\mathrm{SiO}_{2}$ rétegeken, mind a 4 beesési szögön végeztem méréseket és meghatároztam az ellipszometriai szögeket. A mintákat egy kereskedelmi forgalomban kapható, nagy pontosságú (Woollam M2000-F típusú) ellipszométer segítségével is megmértem, ami alapján azt a megállapítást tettem, hogy az általam épített eszközzel a spektroszkópiai ellipszométerhez képest $\Psi$ esetén $6 \%, \Delta$ esetén $1 \%$ alatti relatív eltéréssel tudom meghatározni a mért adatokat.

A következö alfejezetben bemutatom azt a kísérleti és elméleti munkát, amely során a megépített null-ellipszométert használtam fel szilícium minták tranziens optikai adatainak vizsgálatára. Ehhez a kísérletekhez az eszközt pumpa-próba elrendezésben használtam, ahol a pumpa nyaláb egy festék-KrF excimer lézer $248 \mathrm{~nm}$-es, 480 fs-os impulzusai voltak. A próba nyaláb ennek az impulzusnak a 496 nm hullámhosszúságú alapharmonikusa volt. Az eszközt és a kidolgozott eljárást sikeresen tudtam használni, így meghatároztam a szilícium minta $\Psi$ és $\Delta$ adatait a gerjesztéstől számított 2-146 ps-os késleltetési tartományon. A mérési eredmények értelmezése során egy olyan elméleti modellt állítottam fel, amely figyelembe vette nemcsak az optikai adatok hőmérsékletfüggését, hanem a lézerimpulzus által gerjesztett szabad töltéshordozók Drudeabszorpciójának hatását is. Ahhoz, hogy megkapjam a hőmérséklet és a töltéshordozó koncentráció időbeli és térbeli eloszlását, megoldottam a kéthőmérséklet modell egyenleteit a COMSOL Multiphysics program segítségével. A kéthőmérséklet modell segítségével meghatározott töltéshordozó és hőmérséklet eloszlásokat figyelembe vevő ellipszometriai modell sikeresen leírta a $\Psi$ és $\Delta$ adatok változását. 


\section{Angol nyelvü összefoglaló}

Laser treatment of different materials is widely applied in industry and in science. Lasers are able to drill, cut and weld materials, furthermore, we can introduce structural changes of the material surface upon laser irradiation, for example hardening, crystallization or amorphization. The exploration of the physical background of these processes has been started long time ago. However, these fields are still intensively investigated nowadays, due to the versatility of materials and laser sources. There are many techniques which are able to follow the surface modification of the laser treated material. During my work I applied two complementary nondestructive methods, Raman-spectroscopy and spectroscopic ellipsometry. These two methods are based on two distinct physical phenomena. Due to this, with the simultaneous application of these methods, the structural changes of the material can be followed in a more accurate way.

Surface properties of materials, for example hardness, wetting and optical behavior can also be changed with pulsed laser treatments. During these modifications periodic surface structures may appear, which are commonly referred as LIPSS (Laser Induced Periodic Surface Structure). The physics behind the formation of these structure is still under investigation. Many experiments have been carried out to examine the effect of the pulse energy, pulse number, pulse duration on the properties of the developing surface structure. However, no systematic study can be found in the literature aiming at the investigation of pulse duration from few tens of femtosecond to the hundreds of picosecond range with the same laser at the same circumstances.

For better understanding of the physics behind the surface modification and the induced changes of the surface, it is necessary to follow the optical (e.g. reflection, absorption and refraction) changes during the laser pulse excitation. These parameters change in a transient way during laser irradiation so the in-situ measurements of them provides useful information. For insitu measurements the pump-probe technique is a commonly used method. During these experiments, the pump beam induce changes on the surface which can be followed by the probe beam. The limitation of these methods is the laser pulse duration. With femtosecond pulse duration the time resolution of the measurement can easily be pushed towards the sub-picosecond range. The optical parameters, i.e. complex refractive index modified during laser treatment, can be measured if we combine the pump-probe technique with the ellipsometry. 
During my $\mathrm{PhD}$ work my aim was to examine the laser-matter interaction in ex-situ and insitu ways as well. For this purpose, I used different pulsed lasers for the modification of glassy carbon and silicon surfaces. In the first part of my work, I examined the surface modification after pulsed laser treatment of glassy carbon with Raman-spectroscopy and spectroscopic ellipsometry. The aim of this work was to elaborate an evaluation method for the Raman-spectra which is able to separate the Raman-spectrum of the topmost layer of the treated samples from the Ramanspectrum of the substrate. To prove the correctness of the method I wanted to use the ellipsometric results as an independent method providing complementary information about the modified surfaces. I wanted to test the method and follow the structural changes on the surfaces treated by nanosecond or sub-picosecond UV and visible pulses.

In the second part of my work I generated periodic surface structures (LIPSS) on glassy carbon surface. For this purpose, I wanted to use infrared and UV laser pulses. The goal of this work was to investigate the effect of the pulse duration and the pulse number of the lasers for the properties of the periodic surface structures formation. Besides, I wanted to determine the physical processes which take part on the LIPSS formation.

In the next part of my work I aimed at changing the previously used ex-situ ellipsometric measurement technique to an in-situ one. The goal of this work was to measure the transient optical changes of the material during the laser-matter interaction. For this purpose, I planned to build an ellipsometric setup in pump-probe arrangement. I wanted to use the setup with UV pump beam excitation and visible probing beam and measure the transient optical changes of silicon wafers.

In the first part of my results, I presented a new evaluation method for Raman spectroscopic measurements. With this method, it is possible to separate the Raman spectrum of thin surface layers from the substrate, if the two spectra are overlapped. This evaluation method is based on the fitting procedure of the measured Raman spectra. To validate the evaluation method I treated glassy carbon (GC) surfaces with nanosecond and sub-picosecond pulse duration Nd:YAG and excimer lasers, and used this method to evaluate the Raman spectroscopic measurements. First, I measured the Raman spectra of the intact GC and fitted with Gaussian functions. The parameters of these functions were fixed during the further steps of the procedure. After this I took the measured Raman spectra of the modified surfaces and fitted them with the combination of the fixed Gaussian functions and three new one. The fixed Gaussian functions were multiplied by a constant, which I 
named the weight factor. This value corresponds to the weakening of the Raman signal of the substrate which traverses the topmost modified layer. Since the weight factor is proportional to the absorption of both the excitation light and the Raman signal of the substrate while travelling through the modified layer, it provides information about the absorption and the thickness of the modified layer. To check these properties the modified layer I carried out ellipsometric measurements on the samples as well. After the evaluation of the Raman spectra I compared the weight factor with the absorption parameters of the layer form the ellipsometric results and I found a good agreement between them. Based on this, I concluded that the elaborated evaluation method is capable of determining the Raman spectra of the topmost layer, even if the layer is transparent and the Raman signal of the substrate is overlapped with that.

In the second part of my results I used this evaluation method for the measured Raman spectra to get structural information about the topmost layer of GC modified by excimer and Nd:YAG laser pulses. From the Raman-spectra of the layer I determined the intensity ratio of the D and G peaks, the full width at half maximum of them, and the position of the G peak. I also determined the optical properties as the extinction, refraction coefficient and the thickness of the modified layer from the ellipsometric measurements. Since the wavelength of the lasers were divers, I interpreted the result as the function of the volumetric fluence, which is the product of the absorption coefficient and the fluence. This value corresponds to the volume in which the pulse energy is absorbed, and it was used successfully by my supervisors earlier in similar cases. I found that on the surface a thin modified layer appeared with thicknesses between 2 and $90 \mathrm{~nm}$, after the laser treatment. The structure of the layers was similar to glassy carbon, but it was more disoriented. The evaluation of the Raman spectroscopic measurements revealed that the structure of the modified layer was close to the nanocrystalline graphite. In case of Nd:YAG treated samples, frozen droplets appeared on electronmicroscope (SEM) images, while such droplets could not be observed on the excimer laser treated samples. I explained this difference with the different ablation processes: with excimer laser treated samples the so called photochemical ablation takes place, but in the case of $\mathrm{Nd}$ :YAG laser the ablation happened in thermal way.

In the next part of my results, I studied a different aspect of the interaction of laser pulses and GC. I wanted to study the LIPSS generation with two different lasers. One of them was a Ti:Sapphire based CPA laser which provides pulses in the near-infrared region, and the other was 
a dye-KrF hybrid laser with pulses in the UV region. During my experiments I systematically varied the pulse number and duration to test whether the periodic structure appear on the surface or not. The formation of the periodic structure was studied by scanning electron microscopy by recording SEM images from the middle of the treated area. I made the Fast Fourier Transform analysis of the images to characterize the observed periodic structures quantitatively and qualitatively.

In the case of the Ti:Sapphire treatment I varied the pulse duration in order of magnitude steps between $35 \mathrm{fs}$ and $200 \mathrm{ps}$. On samples which were treated with $30 \mathrm{ps}$ or higher pulse durations the SEM images showed frozen droplets on the surface. Based on this information, I conclude that the thermalization time of the GC can be in the order of few picosecond. I observed sub-200 nm ripples on those samples which were treated with $35 \mathrm{fs}-2.4$ ps pulse durations. If the pulse duration was longer than the thermalization time, the distance between the periodic structures was roughly the same as the laser wavelength. From this results I concluded that the physical effect behind the larger periodic structures can be the formation of capillary waves which appear in the molten surface layer during the treatment. For the treatment with 200 ps, SEM images were taken at the periphery of the treated area as well. While in the middle wavy like structures appeared with $\sim 800$ $\mathrm{nm}$ distances, at the periphery, where the local fluence of the laser pluses were less, ripple structure with few $100 \mathrm{~nm}$ distances was visible. In addition to this, the small ripples had a 3D fibrous structure. These results indicated that the local fluence in the treated area is important during the LIPSS formation. In all cases the direction of the structures was parallel with the polarization of the laser pulses.

In the case of the dye- $\mathrm{KrF}$ laser treatment I varied the pulse duration between $250 \mathrm{fs}$ and 2.1 ps. I also observed LIPSS formation with two different periodicities on the samples, but the two different kinds of ripples appeared in all cases independently from the pulse duration. One of them was parallel with the laser polarization direction and the characteristic distances were close to the wavelength of the laser pluses. The other one was perpendicular to the polarization direction and had a sub-100 $\mathrm{nm}$ periodicity.

In the next part of my results I presented the establishment of an imaging null-ellipsometer, which I designed and built to measure transient optical properties. The null-ellipsometer is the simplest ellipsometer, which is based on the nulling condition of the light reflected from the 
sample. For such a measurement the unpolarized light goes through a polarizer, a quarter wave plate, is reflected from the sample and passes through the second polarizer (analyzer). The nulling condition can be achieved with the alignment of the azimuth angles of the polarizer and analyzer. I elaborated a method for setting the nulling condition in a more accurate way. This method is based on the systematic scanning of the polarizer and analyzer angles resulting in an intensity map. To determine the ellipsometric angles ( $\Psi$ and $\Delta$ ) I fitted with the map with exact expression describing theoretically the intensity distribution. To get information about the accuracy of the device, I measured the $\Psi$ and $\Delta$ angles of two different thermally grown $\mathrm{SiO}_{2}$ samples at all angles of incidence. Besides I measured the ellipsometric angles with a commercial Woollam M2000-F ellipsometer as well. Comparing the two measurements I found that the relative deviation of the null-ellipsometric measurements was less than $6 \%$ in $\Psi$ and $1 \%$ in $\Delta$.

In the last part of my results I presented an experimental and theoretical work related to the null-ellipsometric measurements done on silicon samples in pump-probe arrangement. During the experiments I used a dye- $\mathrm{KrF}$ eximer laser. The pump beam contained the $248 \mathrm{~nm}$ UV pulses and the probe beam was a small part of the seed pulses with $496 \mathrm{~nm}$ wavelength. The pulse duration of the pulses were $480 \mathrm{fs}$. I could determine the $\Psi$ and $\Delta$ angles of the silicon samples between 2 and 146 ps delay after the excitation. To describe the transient changes of the ellipsometric angles I constructed a model that considers the free carrier and lattice temperature distribution of the samples by combining a gradient- and a Drude-model with the temperature dependent optical properties of $\mathrm{Si}$. For this purpose, I programed a two temperature model in COMSOL Multiphysics. This program could provide the necessary information about the lattice temperature and the free carrier concentration distribution at different time instants after excitation. Based on these data, I could describe the $\Psi$ and $\Delta$ changes of the silicon sample during the excitation. 


\section{Saját publikációk}

\section{Tézispontokhoz kötödö publikációk:}

[T1, T2] J. Csontos, Z. Pápa, A. Gárdián, M. Füle, J. Budai, Z. Toth: Spectroscopic ellipsometric and Raman spectroscopic investigations of pulsed laser treated glassy carbon surfaces, Applied Surface Science 336 (2015) 343-348

[T3] J. Csontos, Z. Toth, Z. Pápa, J. Budai, B. Kiss, A. Börzsönyi, M. Füle: Periodic structure formation and surface morphology evolution of glassy carbon surfaces applying 35-fs200-ps laser pulses, Applied Physics A 122 (2016) 593

[T4, T5] J. Csontos, Z. Toth, Z. Pápa, B. Gábor, M. Füle, B. Gilicze, J. Budai: Ultrafast insitu null-ellipsometry for studying pulsed laser - Silicon surface interactions, Applied Surface Science 421 (2017) 325-330

\section{Egyéb publikációk:}

Z. Pápa, J. Budai, I. Hanyecz, J. Csontos, Z. Toth: Depolarization correction method for ellipsometric measurements of large grain size zinc-oxide films, Thin Solid Films 571 (2014) 562566

M. Füle, A. Gárdián, J. Csontos, J. Budai, Z. Toth: Ti: Sapphire laser ablation of silicon in different ambients, Journal of Laser Micro Nanoengineering 9 (2014) 119-125

Z. Toth, I. Hanyecz, A. Gárdián, J. Budai, J. Csontos, Z. Pápa, M. Füle: Ellipsometric analysis of silicon surfaces textured by ns and sub-ps KrF laser pulses, Thin Solid Films 571 (2014) 631-636

Z. Pápa, J. Csontos, T. Smausz, Z. Toth, J. Budai: Spectroscopic ellipsometric investigation of graphene and thin carbon films from the point of view of depolarization effects, Applied Surface Science 421, (2017) 714-721

A. T. Seifi, M. Ouille, A. Vernier, F. Bohle, E. Escoto, S. Kleinert, R. Romero, J. Csontos, U. Morgner, G. Steinmeyer, H. Crespo, R. Lopez-Martens, T. Nagy: Propagation effects in the characterization of 1.5-cycle pulses by XPW dispersion scan, IEEE Journal of Selected Topics in Quantum Electronics, 25 (2019)

Z. Pápa, E. Kecsenovity, J. Csontos, A. Szabó, Z. Toth, J. Budai: Ellipsometric Analysis of Aligned Carbon Nanotubes for Designing Catalytic Support Systems, Journal of Nanoscience and Nanotechnology 19 (2019) 395-399 


\section{Köszönetnyilvánítás}

Köszönettel tartozom témavezetőimnek dr. Tóth Zsoltnak és dr. Budai Juditnak, akik bevezettek a tudományos élet rejtelmeibe és megmutatták a lézeres anyagmegmunkálásban valamint a Raman-spektroszkópiában és az ellipszometriában rejlő lehetőségeket. Köszönöm Nekik azokat a segítségeket, iránymutatásokat, tanácsokat, amiket doktori munkám és értekezésem elkészítése során kaptam.

Külön köszönettel tartozom munkatársamnak és barátomnak dr. Pápa Zsuzsannának, aki saját munkái mellett mindig tudott időt szakítani rám, ha segítségre vagy tanácsra volt szükségem. Köszönöm barátaimnak a támogatást és a bátorítást a nehezebb napokon.

Meg szeretném köszönni kollégáimnak, név szerint dr. Füle Miklósnak, dr. Hanyecz Istvánnak, Bálintné Gárdián Anettnek és Gábor Bencének, akik segítsége nélkül a tudományos cikkeim nem készülhettek volna el.

Köszönettel tartozom az Optikai és Kvantumelektronikai Tanszék, valamint a Kísérleti Fizika Tanszék mindenkori vezetőinek, hogy rendelkezésemre bocsátották a kísérleteimhez szükséges erőforrásokat, eszközöket, lézereket. Megköszönném Gilicze Barnabásnak a High Intensity Laser Laboratory dolgozójának, hogy kísérleteim során bátran fordulhattam hozzá kérdéseimmel, kéréseimmel. Továbbá hálás vagyok a TeWaTi laborban dolgozóknak, dr. Börzsönyi Ádámnak, dr. Kiss Bálintnak, valamint Flender Rolandnak, hogy kísérleteim során maximális támogatásukat élvezhettem.

Hálás vagyok családomnak és páromnak Zsebők Líviának, akik a nehéz napokon támogattak és bíztattak, Nélkülük nem jutottam volna el idáig. 


\section{Irodalomjegyzék}

[1] Dieter Bäuerle, Laser Processing and Chemistry, Springer, (2000)

[2] Budai Judit, PhD értekezés, Szeged (2008)

[3] Á. Mechler, P. Heszler, Zs. Márton, M. Kovács, T. Szörényi, Z. Bor, Appl. Surf. Sci.154 (2000) 22.

[4] H. Saitoh, T. Shinada, Y. Ohkawara, S. Ohshio, H. Hiraga, T. Inoue, Jpn. J. Appl. Phys. 41 (2002) 3890.

[5] H. Saitoh, T. Shinada, Y. Ohkawara, S. Ohshio, H. Hiraga, T. Inoue, Jpn. J. Appl. Phys. 41 (2002) 5359.

[6] M. Bonelli, A. Miotello, Phys. Rev. B 59 (1999) 13513.

[7] M.D. Shirk, P.A. Molian, Carbon 39 (2001) 1183.

[8] H.O. Jeschke, M.E. Garcia, K.H. Bennemann, Appl. Phys. A 69 (1999) 49.

[9] V.V. Iyengar, B.K. Nayak, K.L. More, H.M. Meyer, M.D. Biegalski, J.V. Li, M.C. Gupta, Solar Energy Mater. Solar Cells 95 (2011) 2745

[10] B.G. Lee, L. Yu-Ting, S. Meng-Ju, E. Mazur, H. M. Branz, Y.-T. Lin, M.-J. Sher, in 38th IEEE Photovoltaic Specialists Conference (PVSC) (IEEE, 2012), p. 1606

[11] V. Zorba, L. Persano, D. Pisignano, A. Athanassiou, E. Stratakis, R. Cingolani, P. Tzanetakis, C. Fotakis, Nanotechnology 17 (2006) 3234

[12] T. Baldacchini, J.E. Carey, M. Zhou, E. Mazur, Langmuir 22 (2006) 4917

[13] Vorobyev, AY, Guo, CL, J. Appl. Phys., 103 (2008) 043513

[14] M. Halbwax, T. Sarnet, Ph. Delaporte, M. Sentis, H. Etienne, F. Torregrosa, V. Vervisch, I. Perichaud, S. Martinuzzi, Thin Solid Films 516 (2008) 6791-6795

[15] M. Birnbaum, Semiconductor Surface Damage Produced by Ruby Lasers, J. Appl. Phys. 36 (1965) 3688

[16] J. Bonse, J. Krüger, S. Höhm, A. Rosenfeld, J. Laser Appl. 24 (2012) 042006

[17] G. Miyaji, K. Zhang, J. Fujita, K. Miyazaki, J. Laser Micro/ Nanoeng. 7 (2012) 198

[18] T.J.-Y. Derrien, R. Koter, J. Krüger, S. Höhm, A. Rosenfeld, J. Bonse, J. Appl. Phys. 116 (2014) 074902 
[19] M. Huang, F. Zhao, Y. Cheng, N. Xu, Z. Xu, ACS Nano 3 (2009) 4062

[20] G.D. Tsibidis, M. Barberoglou, P.A. Loukakos, E. Stratakis, C. Fotakis, Phys. Rev. B 86 (2012) 115316

[21] Y. Han, S. Qu, Chem. Phys. Lett. 495 (2010) 241

[22] T.J.-Y. Derrien, J. Krüger, T.E. Itina, S. Höhm, A. Rosenfeld, J. Bonse, Opt. Express 21 (2013) 29643

[23] T.J.-Y. Derriena, R. Torresa, T. Sarneta, M. Sentisa, T.E. Itina, Appl. Surf. Sci. 258 (2012) 9487

[24] M. Füle, A. Gárdián, J. Budai, Z. Tóth, J. Laser Micro/Nanoeng. 10 (2015) 74

[25] J.E. Sipe, J.F. Young, J.S. Preston, H.M. van Driel, Phys. Rev. B 27 (1983) 1141

[26] Q. Wu, Y. Ma, R. Fang, Y. Liao, Q. Yu, X. Chen, K. Wang, Appl. Phys. Lett. 82 (2003) 1703

[27] M. Pfeiffer, A. Engel, H. Gruettner, K. Guenther, F. Marquardt, G. Reisse, S. Weissmantel, Appl. Phys. A Mater. Sci. Process. 110 (2013) 655

[28] M. Csete, Z. Bor, Appl. Surf. Sci. 133 (1998) 5

[29] M. Huang, F. Zhao, Y. Cheng, N. Xu, Z. Xu, Phys. Rev. B 79 (2009) 125436

[30] G. Miyaji, K. Miyazaki, Opt. Express 16 (2008) 16265

[31] G. Miyaji, K. Miyazaki, K. Zhang, T. Yoshifuji, J. Fujita, Opt. Express 20 (2012) 14848

[32] E.L. Gurevich, S.V. Gurevich, Appl. Surf. Sci. 302 (2014) 118

[33] E.L. Gurevich, Appl. Surf. Sci. 278 (2013) 52

[34] V.I. Emelyanov, V.N. Seminogov, Kvantovaya Elektron. Mosc. 11 (1984) 871

[35] W. Zhang, G. Cheng, Q. Feng, Appl. Surf. Sci. 263 (2012) 436

[36] A. Borowiec, H.K. Haugen, Appl. Phys. Lett. 82 (2003) 4462

[37] D. Dufft, A. Rosenfeld, S.K. Das, R. Grunwald, J. Bonse, J. Appl. Phys. 105 (2009) 034908

[38] T.Q. Jia, H.X. Chen, M. Huang, F.L. Zhao, J.R. Qiu, R.X. Li, Z.Z. Xu, X.K. He, J. Zhang, H. Kuroda, Phys. Rev. B 72 (2005) 125429

[39] J. Bonse, M. Munz, H. Sturm, J. Appl. Phys. 97 (2015) 013538 
[40] R. Le Harzic, D. Dörr, D. Sauer, M. Neumeier, M. Epple, H. Zimmermann, F. Stracke, Opt. Lett. 36 (2011) 229

[41] J. Reif, F. Costache, M. Henyk, S.V. Pandelov, Appl. Surf. Sci. 197 (2002) 891

[42] O. Varlamova, F. Costache, J. Reif, M. Bestehorn, Appl. Surf. Sci. 252 (2006) 4702

[43] F. Costache, M. Henyk, J. Reif, Appl. Surf. Sci. 208(209) (2003) 486

[44] M. Huang, F. Zhao, Y. Cheng, N. Xu, Z. Xu, Phys. Rev. B 79 (2009) 125436

[45] E.V. Golosov, A.A. Ionin, YuR Kolobov, S.I. Kudryashov, A.E. Ligachev, S.V. Makarov, YuN Novoselov, L.V. Seleznev, D.V. Sinitsyn, A.R. Sharipov, Phys. Rev. B 83 (2011) 115426

[46] M. Huang, F. Zhao, Y. Cheng, Z. Xu, Opt. Lett. 37 (2012) 677

[47] A. Beltaos, A.G. Kovacevic, A. Matkovic, U. Ralevic, S. Savic- Sevic, D. Jovanovic, B.M. Jelenkovic, R. Gajic, J. Appl. Phys. 116 (2014) 204306

[48] W. Zhang, M. Zhou, G. Amoako, Y-L. Shao, B-J. Li, J. Li, C-Y. Gao, Lasers Eng. 25 (2013) 397

[49] C. Popescu, G. Dorcioman, B. Bita, C. Besleaga, I. Zgura, C. Himcinschi, A.C. Popescu, Appl. Surf. Sci. 390 (2016) 236-243

[50] M.C. Downer, R.L. Fork, C.V. Shank, J. Opt. Soc. Am. B 2 (1985) 595-599.

[51] C.V. Shank, R. Yen, C. Hirlimann, Phys. Rev. Lett. 50 (1983) 454-457.

[52] K. Sokolowski-Tinten, D. von der Linde, Phys. Rev. B 61 (2000) 2643-2650.

[53] D. von der Linde, K. Sokolowski-Tinten, Appl. Surf. Sci. 154-155 (2000) 1-10.

[54] A.J. Sabbah, D.M. Riffe, Phys. Rev. B 66 (2002) 165217.

[55] W. He, I.V. Yurkevich, A. Zakar, A. Kaplan, Thin Solid Films 592 (2015) 287-291.

[56] J. Jasapara, M. Mero, W. Rudolph, Appl. Phys. Lett. 80 (15) (2002) 2637-2639.

[57] D.H. Auston, C.V. Shank, Phys. Rev. Lett. 32 (20) (1974) 1120-1123.

[58] H.R. Choo, X.F. Hu, M.C. Downer, V.P. Kesan, Appl. Phys. Lett. 63 (11) (1993) 1507-1509.

[59] F. Boschini, H. Hedayat, C. Piovera, C. Dallera, A. Gupta, E. Carpene, Rev. Sci. Instrum. 86 (013909) (2015) 1-9.

[60] S. Rapp, M. Kaiser, M. Schmidt, H.P. Huber, Opt. Express 24 (16) (2016) 17572-17592. 
[61] H. Bergner, V. Bruckner, L. Leine, M. Supianek, Appl. Phys. A 43 (1987) 97-104.

[62] Pozsgai Imre: A pásztázó elektronmikroszkópia és az elektronsugaras mikroanalízis alapjai, ELTE Eötvös Kiadó Kft. (1995)

[63] Kamarás Katalin, Spektroszkópia és anyagszerkezet, egyetemi jegyzet, BME (2000)

[64] M. Koós, M. Veres, S. Tóth, M. Füle, Top. Appl. Phys. 100447 Springer-Verlag, Berlin, Heidelberg, (2006)

[65] P. Larkin, Infrared and Raman spectroscopy - Principles and spectral interpretation, Elsevier (2011)

[66] E. Smith, G. Dent, Modern Raman Spectroscopy - A practical Approach, John Wiley and Sons Ltd. (2005)

[67] J. Robertson, Materials Science and Engineering R 37 (2002) 129-281

[68] Y. Wang, Daniel C. Alsmeyer, and Richard L. McCreery, Chem. Mater. 2 (1990) 557-563

[69] P. J. F. Harris, Philosophical Magazine 84 (2004) 3159-3167

[70] R.J. Nemanich, S.A. Solin, Phys. Rev. B 20 (1979) 392

[71] Y. Wang, D.C. Alsmeyer, R.L. McCreery, Chem. Mater. 2 (1990) 557

[72] S.-K. Sze, N. Siddique, J.J. Sloan, R. Escribano, Atmos. Environ. 35 (2001) 561.

[73] A. Cuesta, P. Dhamelincourt, J. Laureyns, Carbon 32 (1994) 1523.

[74] A. Sadezky, H. Muckenhuber, H. Gorhe, R. Niessner, U. Pöschl, Carbon 43 (2005) 1731.

[75] R. J. Nemanich, J. T. Glass, G. Lucovsky, and R. E. Shroder, J. Vac. Sci. Technol. A 6, 1783 (1988)

[76] A. C. Ferrari, A. LiBassi, B. K. Tanner, V. Stolojan, J. Yuan, L. M. Brown, S. E. Rodil, B. Kleinsorge, J. Robertson, Phys. Rev. B 62 (2000) 11089

[77] Hiroyuki Fujiwara, Spectroscopic Ellipsometry, John Wiley \& Sons, Ltd. (2009)

[78] Harland G. Tompkins, Eugene A. Irene, Handbook of ellipsometry, Springer (2005)

[79] R. M. A. Azzam, N. M. Bashara, Ellipsometry and polarized light, North-Holland Physics Publishing, (1987)

[80] P. Petrik, PhD disszertáció, BME MTA MFA (1999)

[81] M. I. Kaganov, I. M. Lifshitz and L. V. Tanatarov, Sov. Phys. JETP 4 (1957) 173-178. 
[82] S. I. Anisimov, B. L. Kapeliovich and T. L. Perelman, Sov. Phys. JETP 39 (1974) 375-377.

[83] A. Rämer, O. Osmani, B. Rethfeld, J. Appl. Phys. 116, 053508 (2014)

[84] H. M. van Driel, Phys. Rev. B 35 (1987) 8166

[85] F. Berz, R. Cooper, S. Fagg, Solid-State Electron. 22(3) (1979) 293

[86] S. Szatmári, High-brightness ultraviolet excimer lasers, Appl. Phys. B 58 (1994) 211.

[87] J. Budai, M. Bereznai, G. Szakacs, E. Szilagyi, Z. Toth, Appl. Surf. Sci. 253 (19) (2007) 8235-8241

[88] K. Sokolowski-Tinten, D. von der Linde, Phys. Rev. B 61 (2000) 2643-2650

[89] http://www.revbase.com/tt/sl.ashx?z=73090c66\&dataid=256059\&ft=1

[90] G. E. Jellison, Jr and F. A. Modine, Appl. Phys. Lett., 69 (1996) 371-373; Erratum, Appl. Phys. Lett., 69 (1996) 2137.

[91] J. Tauc, R. Grigorovici, and A. Vancu, Phys. Stat. Sol., 15 (1966) 627-637.

[92] D. De Sousa Meneses, M. Malki, P. Echegut, J. Non-Cryst. Solids 352 (2006) 769.

[93] D. De Sousa Meneses, M. Malki, P. Echegut, J. Non-Cryst. Solids 352 (2006) 769. (2006) 769.

[94] J. Bonse, K.-W. Brzezinka, A. J. Meixner, Appl. Surf. Sci. 221 (2004) 215

[95] J. Mur, L. Pirker, N. Osterman, R. Petkovšek, Optics Express 25 (2017) 26356

[96] L. Kurpaska, M. Frelek-Kozak, K. Nowakowska-Langier, M. Lesniak, J. Jasinski, J. Jagielski, Nucl. Instr. Meth. Phys. Res. B 409 (2017) 81.

[97] G.E. Jellison Jr., F.A. Modine, Appl. Phys. Lett. 69 (1996) 371.

[98] C. Barbero and R. Kötz, J. Electrochem. Soc., 140 (1993) 1-6

[99] M. Williams and E. T. Arakawa, J. Appl. Phys., 43, (1972) 3460.

[100] N. Savvides, J. Appl. Phys. 59 (1986) 4133

[101] A. Sadezky, H. Muckenhuber, H. Grothe, R. Niessner, U. Pöschl, Carbon 43 (2005) 17311742

[102] E. Gamaly, Femtosecond Laser-Matter Interactions, Pan Stanford Publishing Pte. Ltd., Singapore (2011) 
[103] D.O. Gericke, M.S. Murillo, M. Schlanges, Phys. Rev. E 65 (2002) 036418

[104] M. Lyon, S.D. Bergeson, G. Hart, M.S. Murillo, Sci. Rep. 5 (2015) 15693

[105] Z. Toth, I. Hanyecz, A. Gardian, J. Budai, J. Csontos, Z. Papa, M. Füle, Thin Solid Films $571(2014) 631$

[106] P.J.F. Harris, Philos. Mag. 84 (2004) 3159 